\title{
أهمية رحلة بن بطوطة كمصدر لاراسة النقوش الكتابية العربية الإسلامية
}

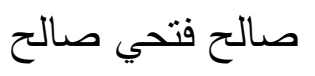

مدرس بقسم الآثار -كلّيّة الآداب-جامعة الدنيا

ملخص البحث:

يُعد هذا البحث من الأهمية بمكان، حيث يلقي بظلاله على النقوش الكتابية العربية الني قرأها أو

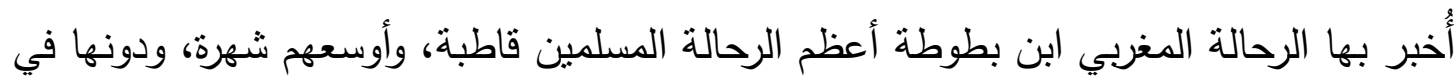

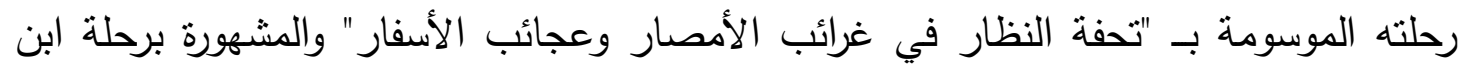

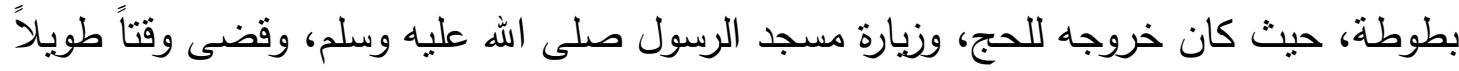

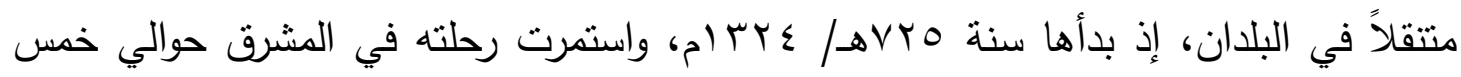

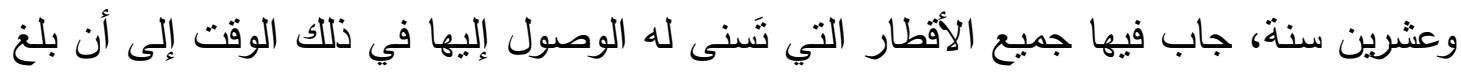

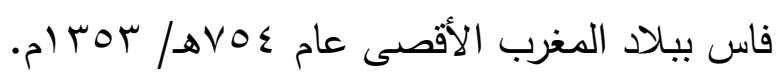

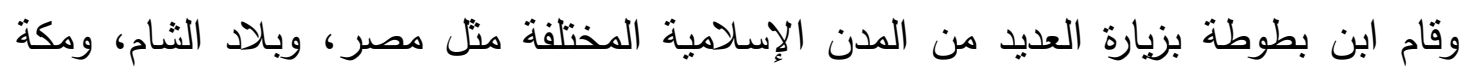

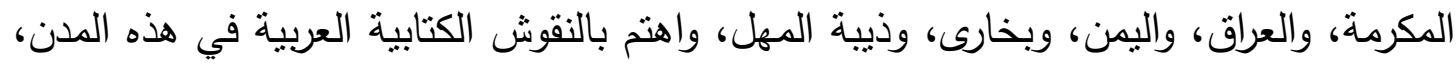

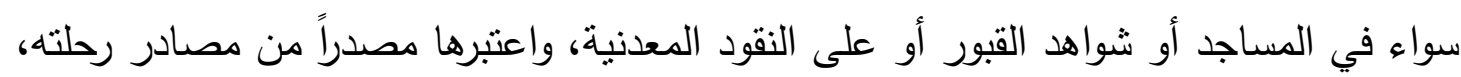

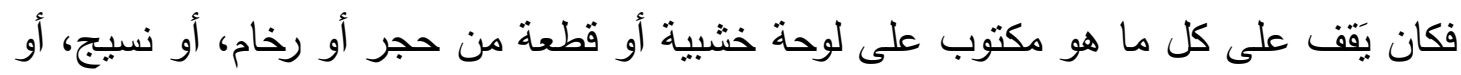

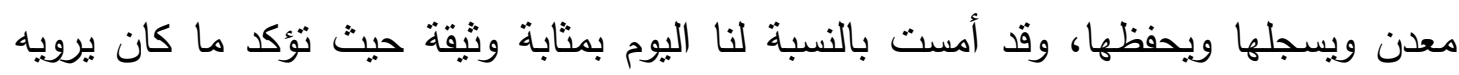

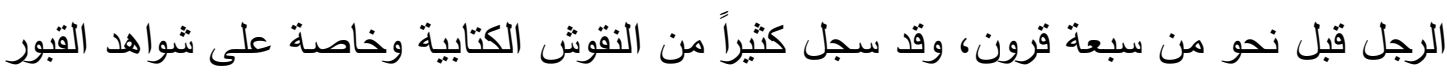

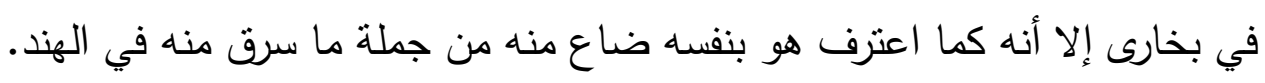

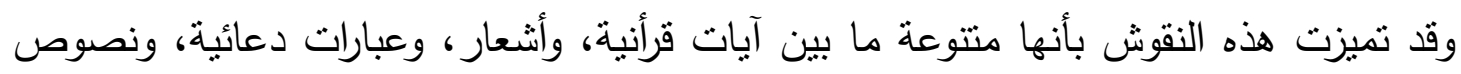
تسجيلية، ونصوص تذكارية، ونصوص جنائزية.

الكلمات الدالة:

$$
\text { צ - ז- - ابن بطوطة نسجلية }
$$

رحلة

نقوش نصوص تنكارية شواهد قبور

مقدمسة

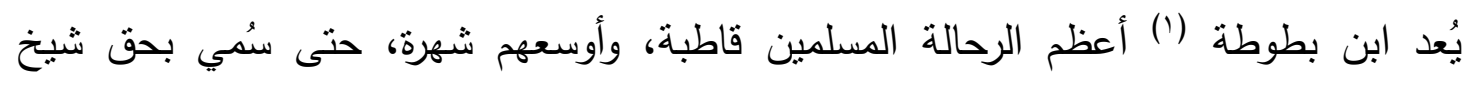

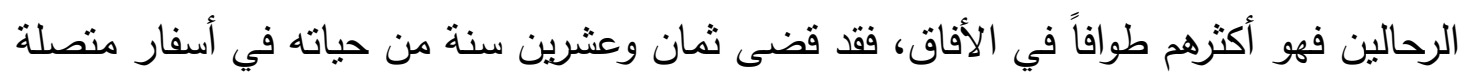


ورحلات متعاقبة (؟). ولا نبالغ إذا قلنا: إن ابن بطوطة هو الرحالة العالمي الأول الذي لم يقطع

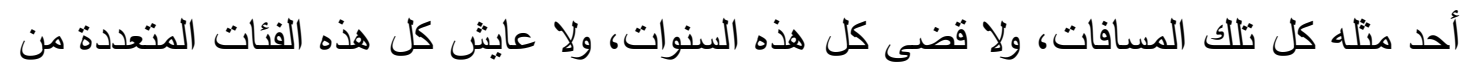

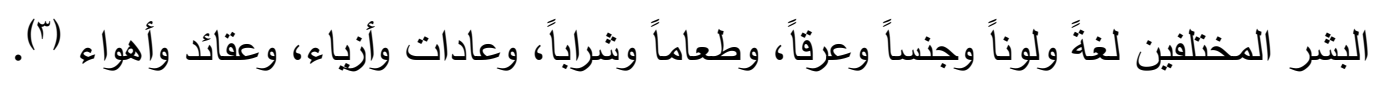
لقد كان خروج ابن بطوطة للحج، وزيارة مسجد الرسول صلى الله عليه وسلم. وقضى وقتاً طويلاً

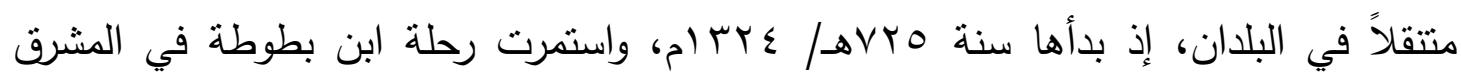

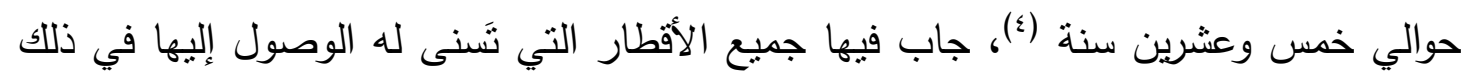

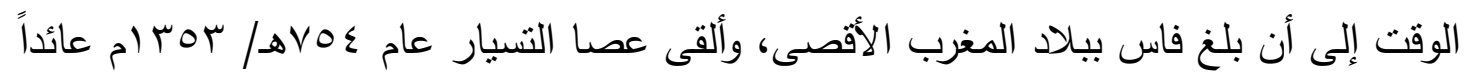

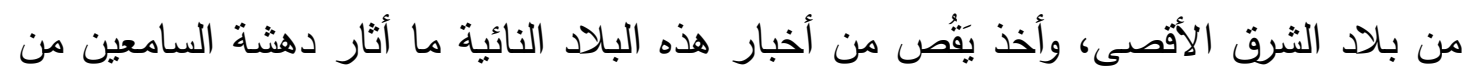

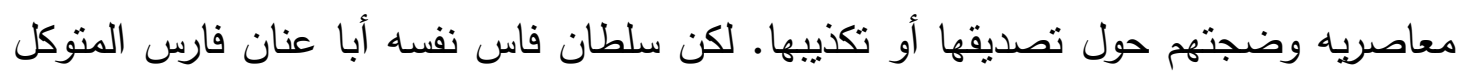

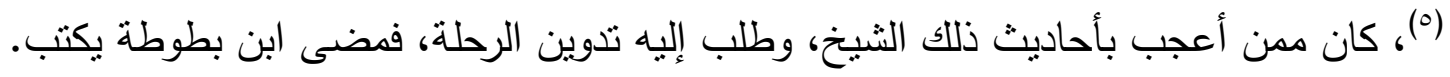

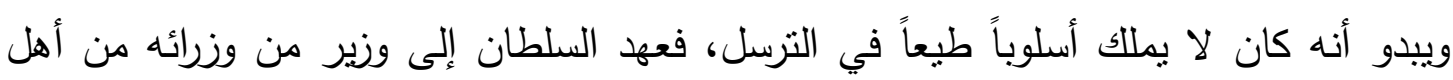

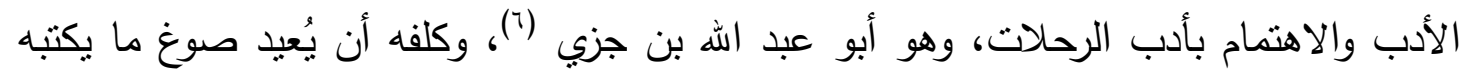

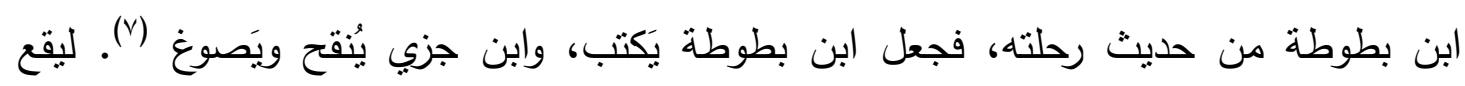

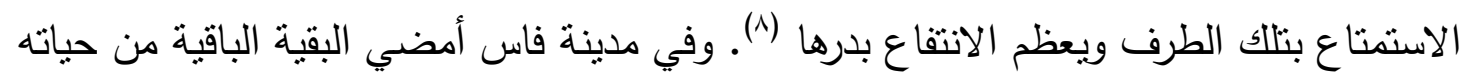

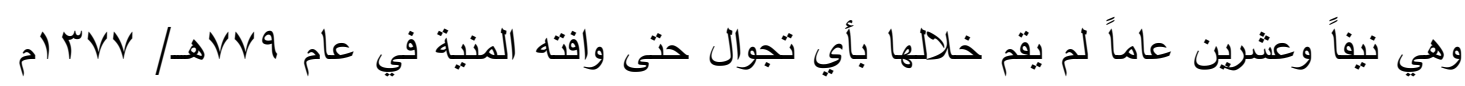

\section{مراحل رحلة ابن بطوطة وقرايته للنقوش الكتابية العربية:}

تُعد رحلة ابن بطوطة من أهم الرحلات في العصور الوسطى سواء على صعيد البلدان عامة أم

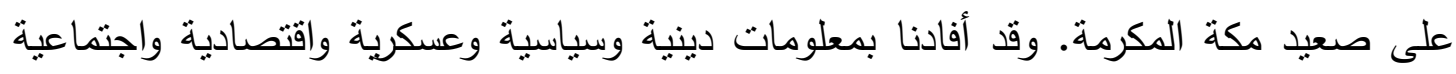

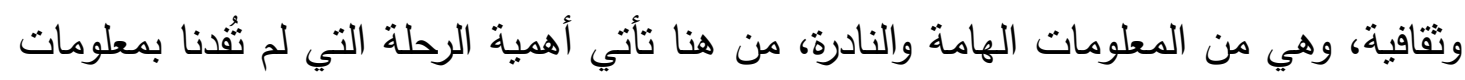

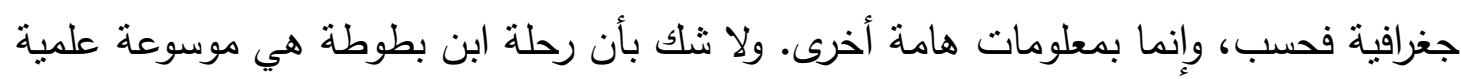
لا يمكن الاستغناء عنها(·'). وقد اهتم ابن بطوطة بوصف الآثار التي شاهدها أثثاء رحلته("')، واهتم بالنقوش التي عليها،

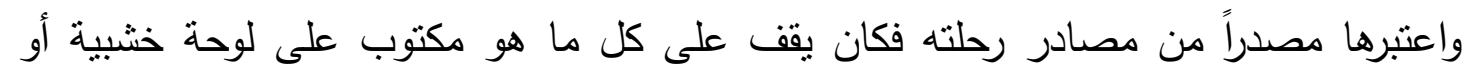

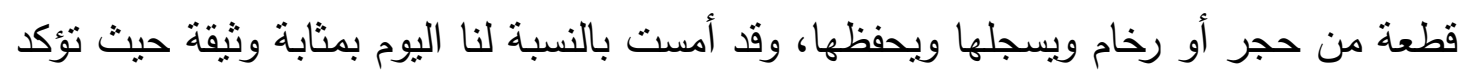

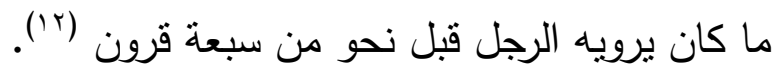

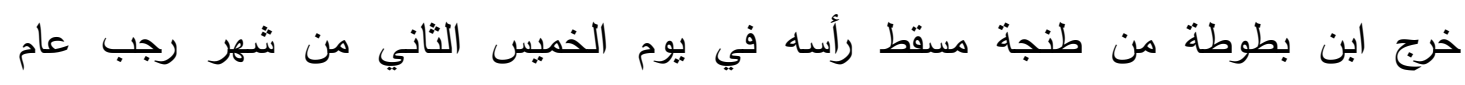

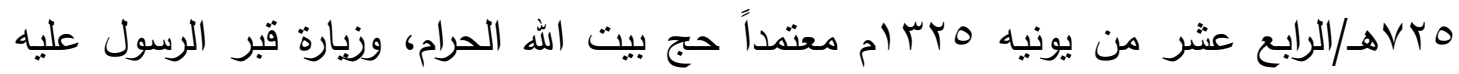


أفضل الصلاة والسلام (r)"، فظل يتتقل من مرحلة إلى أُخرى حتى وصل إلى مدينة تونس، ونزل

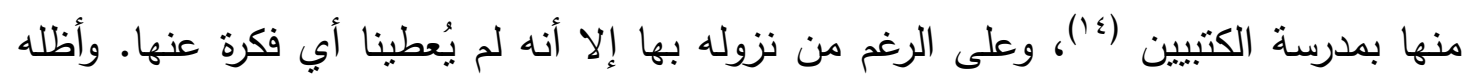

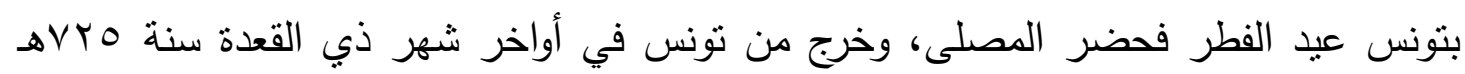

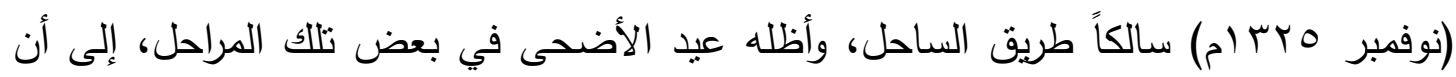

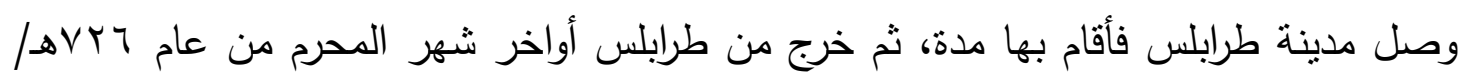

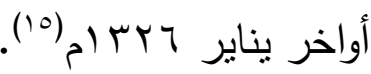

\section{النقوش التي قرأها وأُخبر بها ابن بطوطة بمصر:}

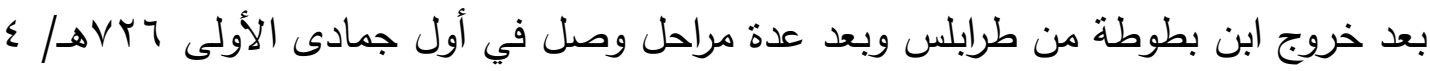

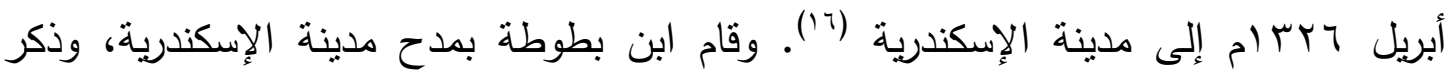

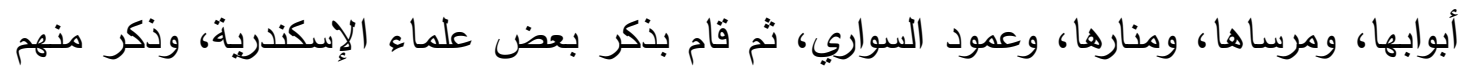

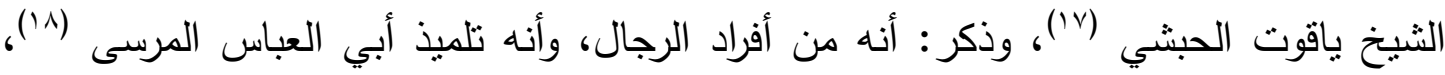

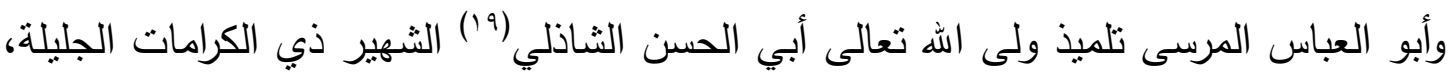

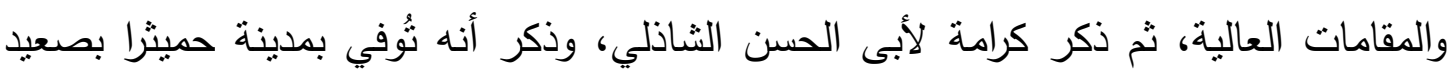

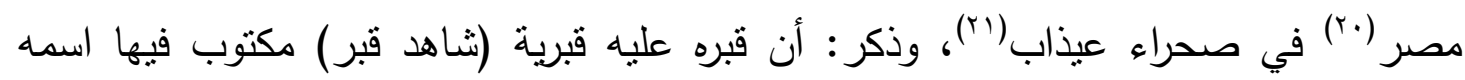

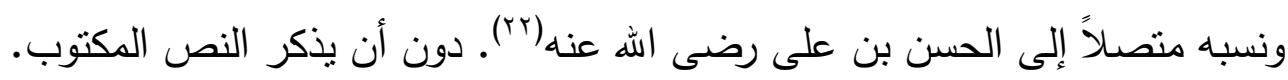

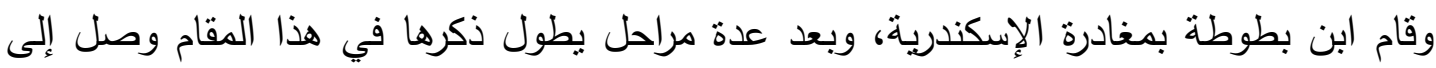

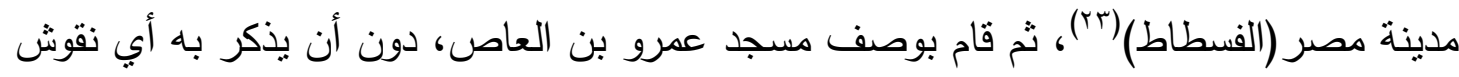

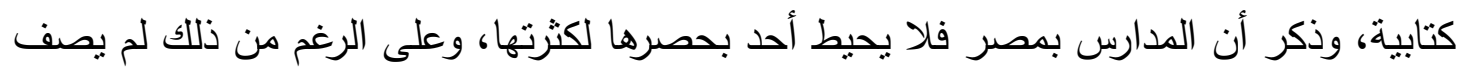

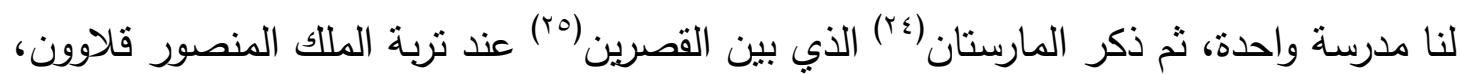
دون ذكر أي نقوش به، وذكر أن الزوايا بمصر كثيرة وهم يسمونها الخوانق، وذكر أن الأمراء

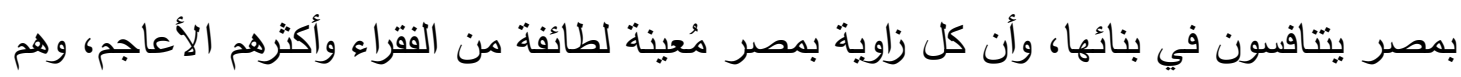

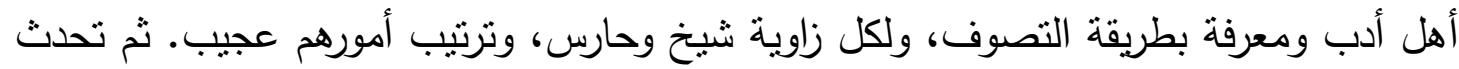

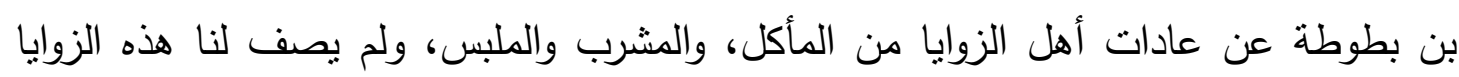

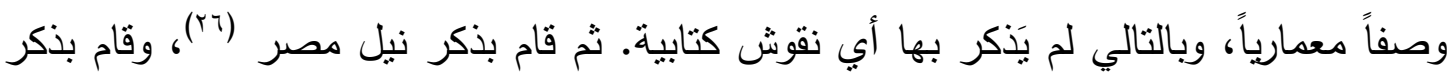

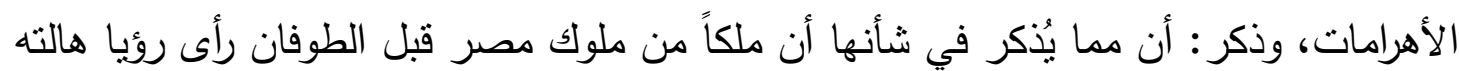

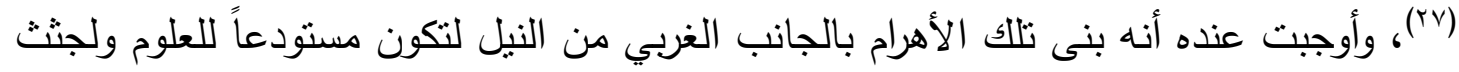

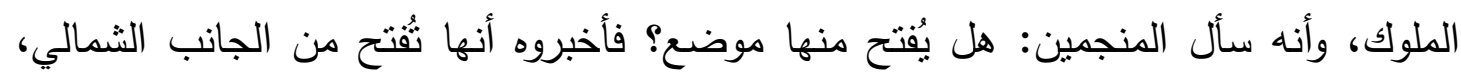

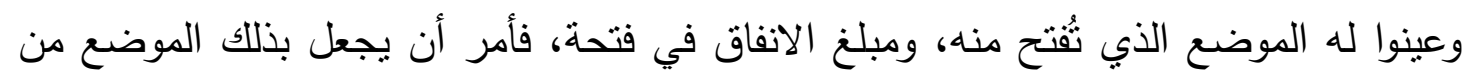


المال قرر ما أخبروه أنه يُنفق في فتحه، واشتن في البناء فأتهه في ستين سنة، وكتب عليها: بنينا

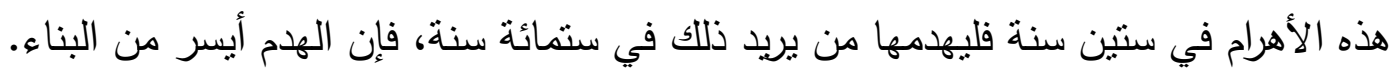

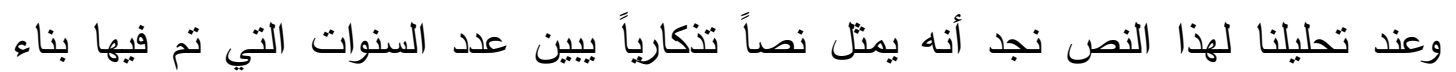

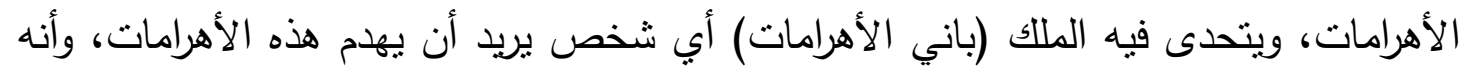

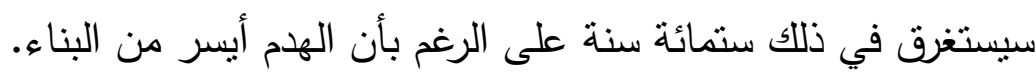

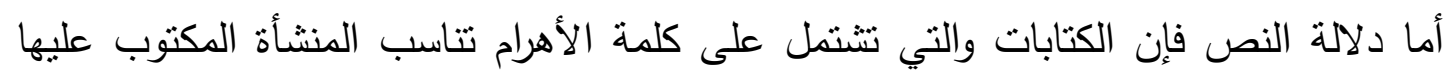
هذه الكتابات وهي الأهرام. ثم كان سفر ابن بطوطة من مصر على طريق الصعيد برسم الحجاز الثريف، فمر على عدة

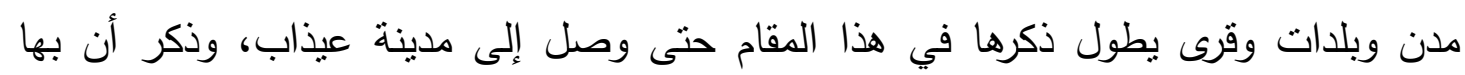
مسجد، دون أن يصفه، وتعذر سفره فعاد مرة أخرى إلى صعيد مصر ، فوصل فئل إلى مدينة قوص.

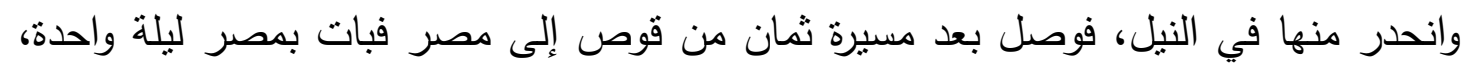
وقصد بلاد الثام. النقوش التي قرأها ابن بطوطة ببلاد الثشام:

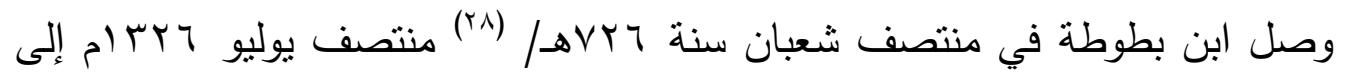

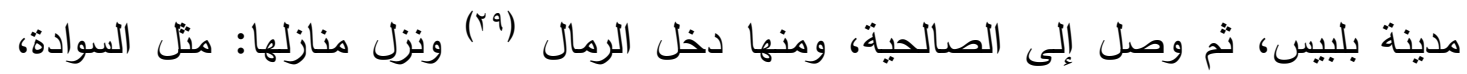
والواردة، والمطيلب، والعريش، والخروبة وبكل منزل منها فندق، وهم يُسمونه الخان ينزله

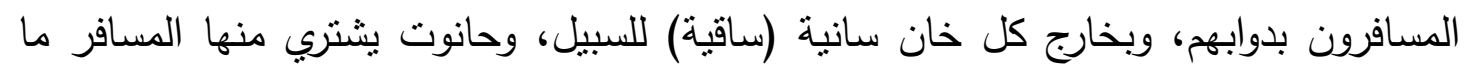

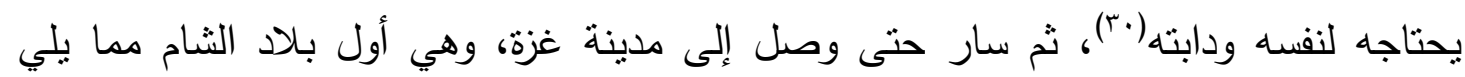

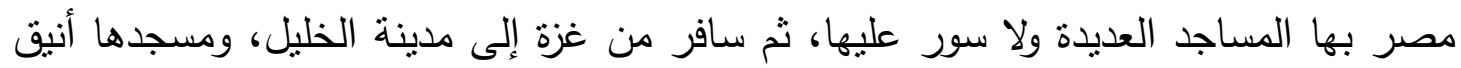

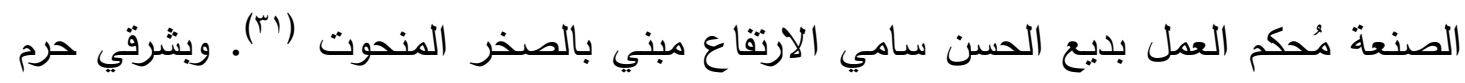

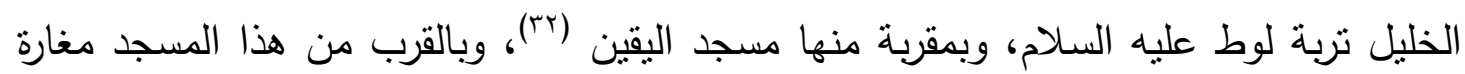

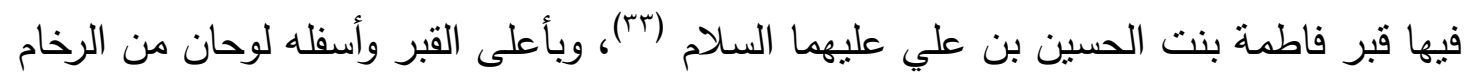
في أحدهما مكتوب منقوش بخط بديع: بسم الهه الرحمن الرحيم، لله العزة والبقاء وله ما ذرأ وبرأ

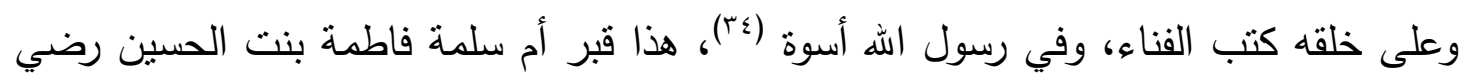

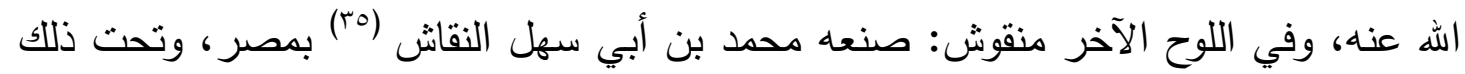
هذه الأبيات:

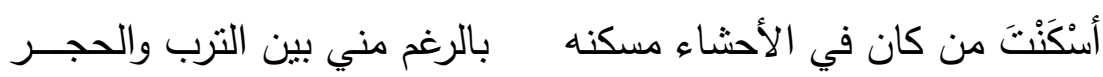

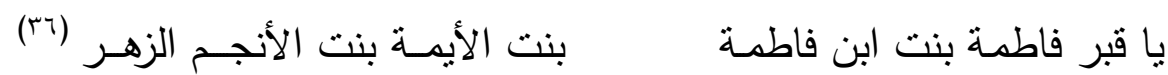




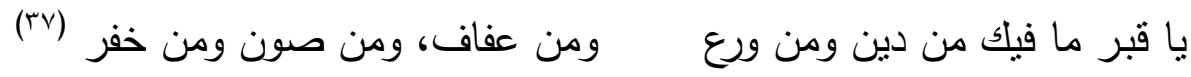
وعند تحليلنا للكتابات نجد أنها عبارة عن نص جنائزى بدأ في اللوح الأول بالبسملة، ثم كلمات

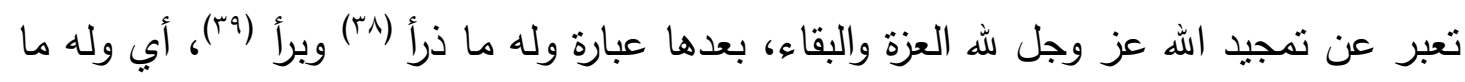

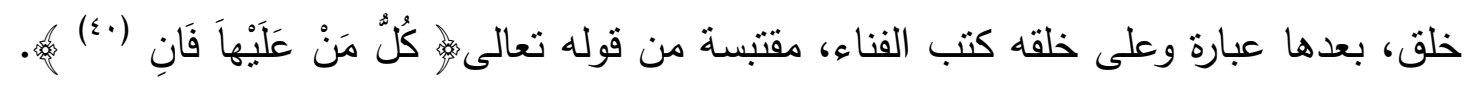

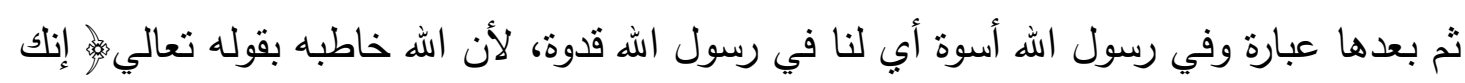

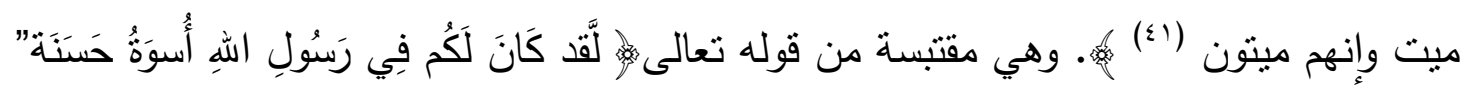

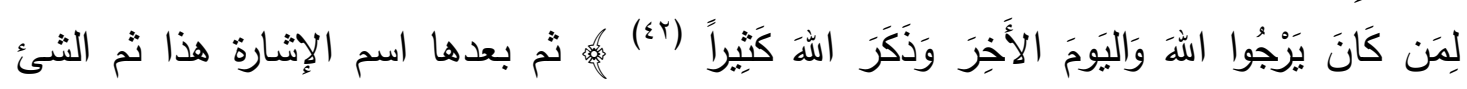

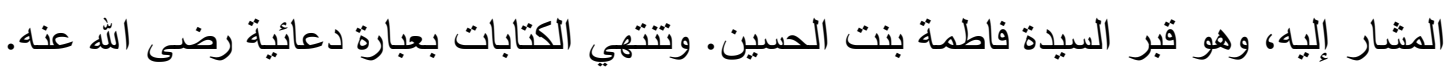

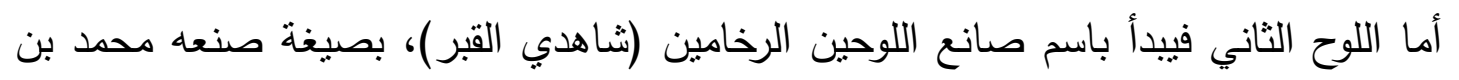

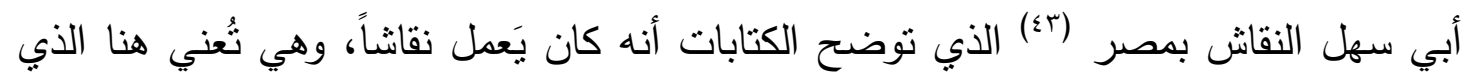

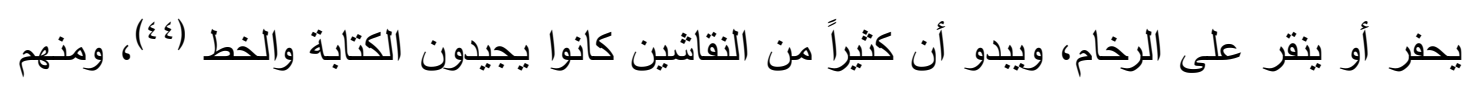

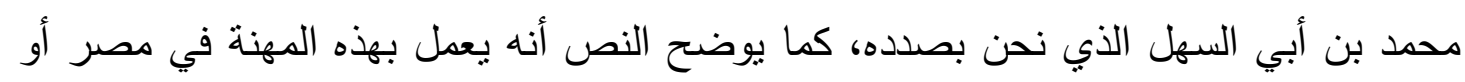

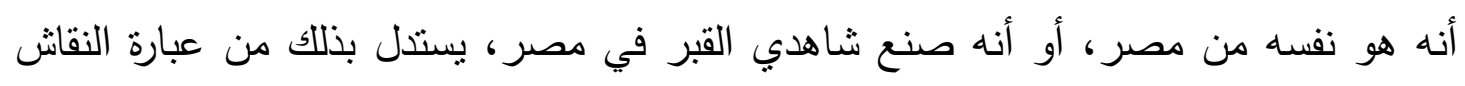

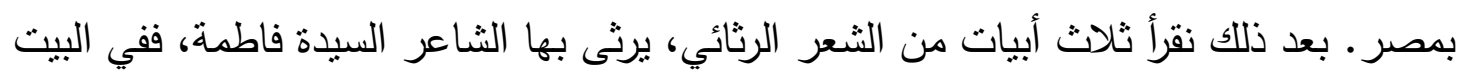

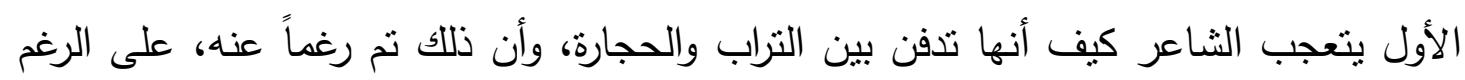

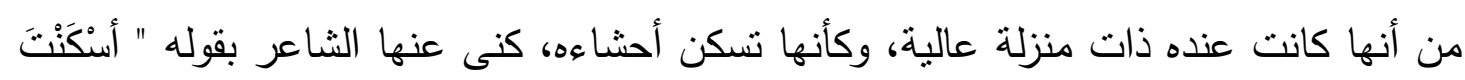

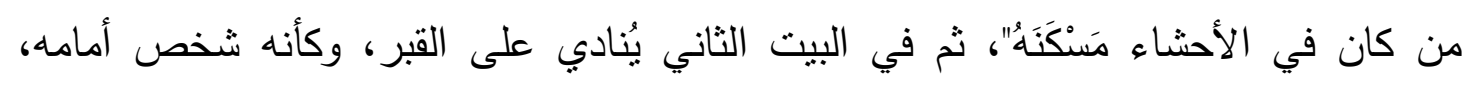

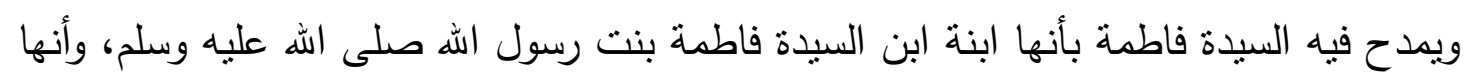
بنت الأئمة فجدها لأمها النبي صلى الله عليه وسلم أمام الأمة الإسلامية جمعاء، وجدها لألها لأبيها

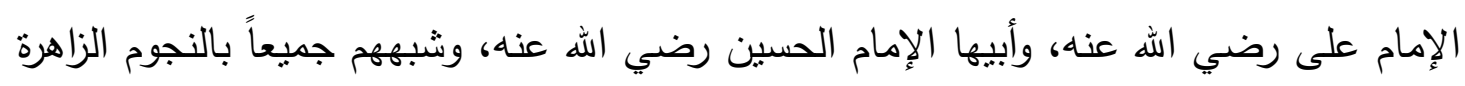

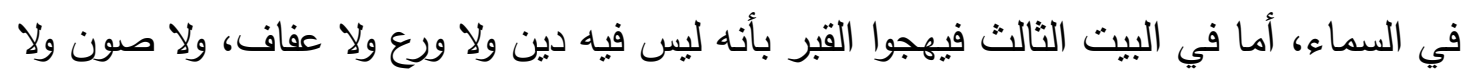
خفر . أما دلالة الكتابات فتتاسب التحفة الموجود عليها الكتابات، وجاءت متتوعة، بعضها يعبر عن

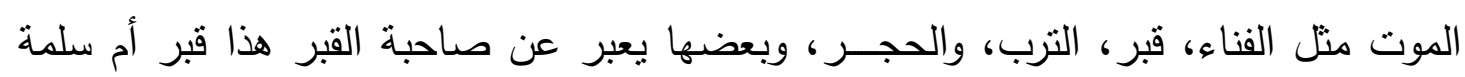

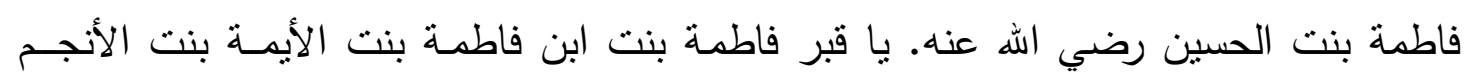

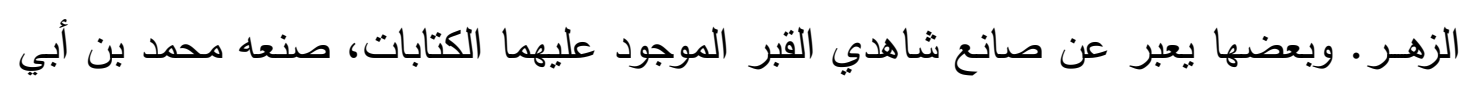

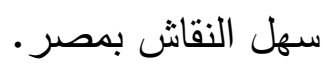


ثم سافر ابن بطوطة من مدينة الخليل إلى القس (؛)؛ـ وذكر المسجد الأقصى إلا أنه قد غفل عن ذكر النقوش الكتابية به، ثم قام بذكر قبة الصخرة دون أن يشير إلى أي نقوش بها أيضاً

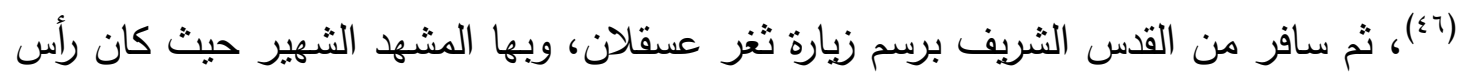

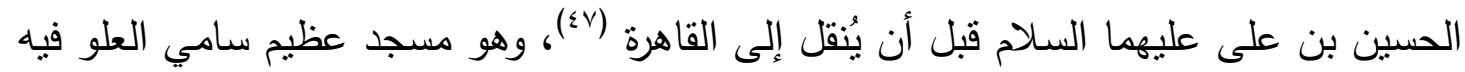

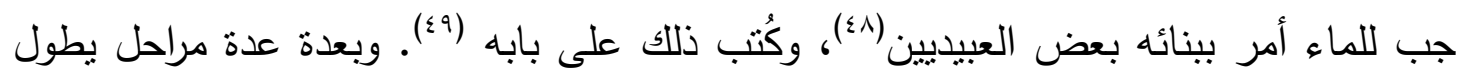

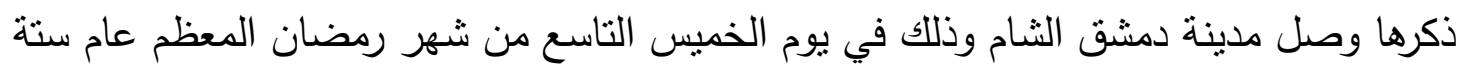

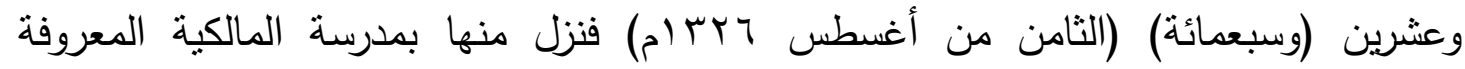
بالثرابشية (.0) ثم قام ابن بطوطة بوصنف من مدينة دمشق ومدحها، وذكر بعض من أنتعار

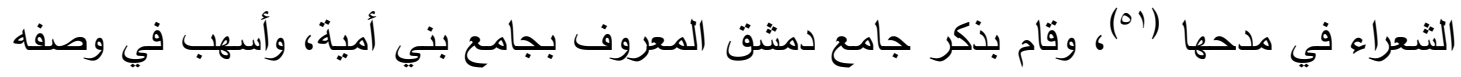

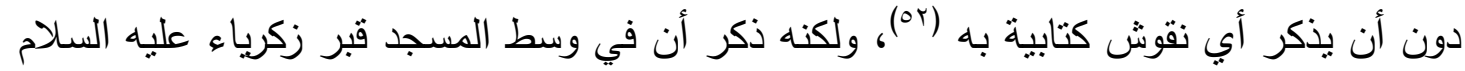

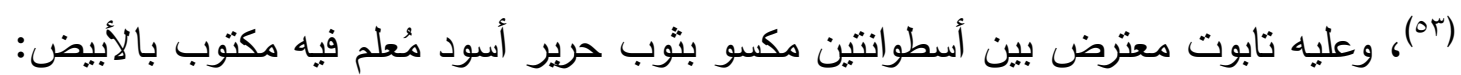

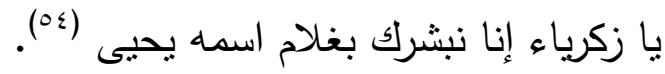
وعند تحليلنا للنص نجد أنه عبارة عن جزء من آية قرأنية رقم V من سورة مريم. أما دلالة الآية

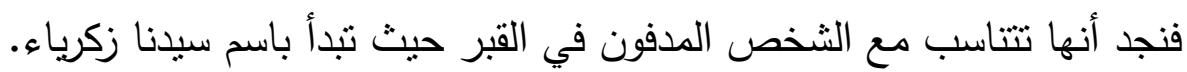

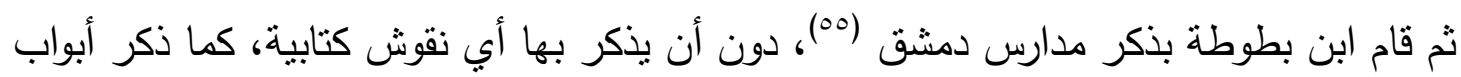

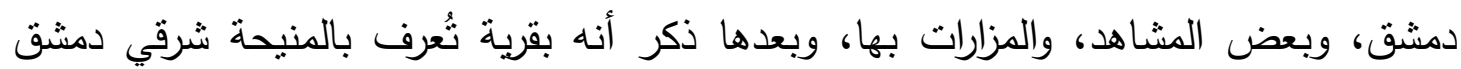

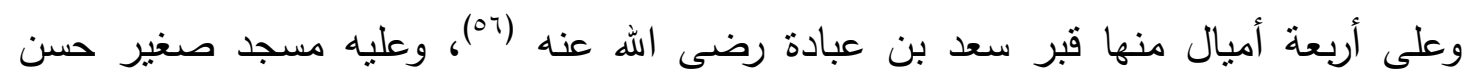

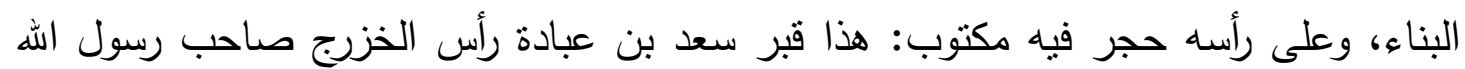
صلى الله عليه وسلم تسليماً( (ov). وعند تحليلنا للنص نجد أنه يبدأ باسم الإثشارة هذا ثم بعدها الثئ المشار إليه وهو قبر سعد بن

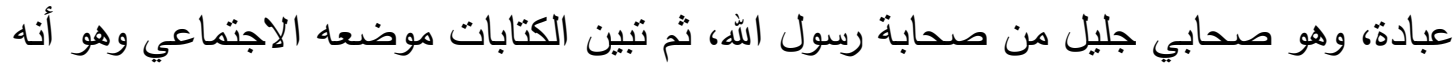

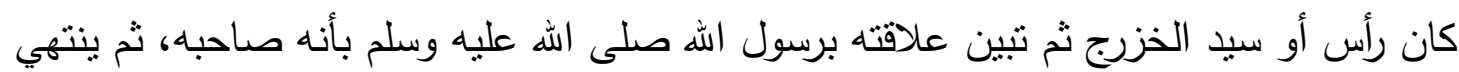
النص بالعبارة الدعائية الملازمة لاسم النبي محمد وهي صلى اله علئ عليه وسلم تسليماً. أما دلالة النص فتتناسب مع اسم الثخص المدفون في القبر ، وهو سعد بن عبادة.

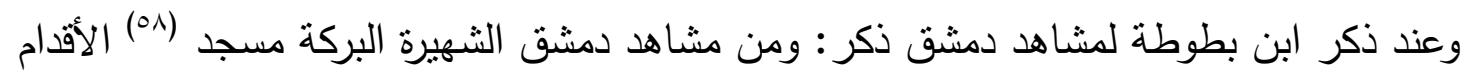

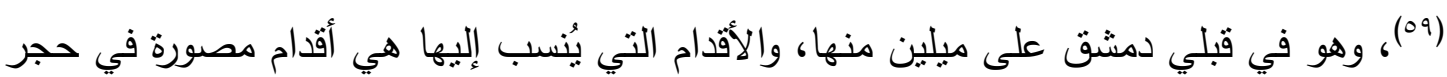

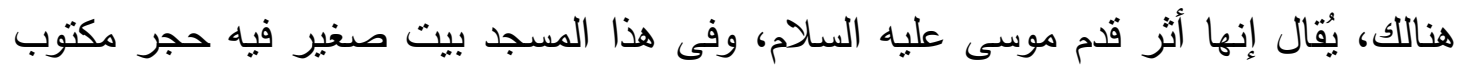


عليه: كان بعض الصالحين برى الدصطفى (.7) صلى الله عليه وسلم في النوم فيقول له: هاهنا

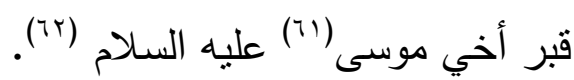
وعند تحليلنا للنص نجد أنه يمثل خبراً أن بعض الصالحين، ولم يُّكر اسمه كان برى النبي

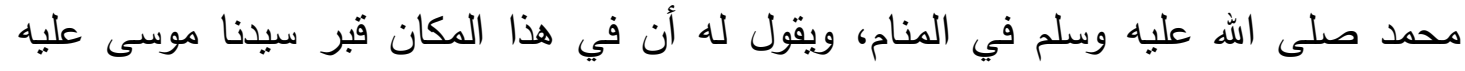

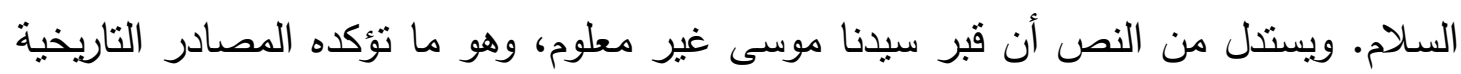
وكتّاب سير الأنبياء. ودلالة النص متعلقة باسم سيدنا موسى الموجود في النص، على الحجر المكتوب عليه النص،

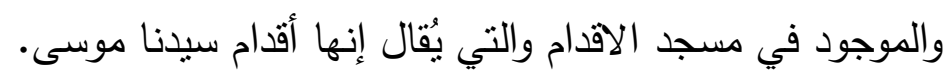

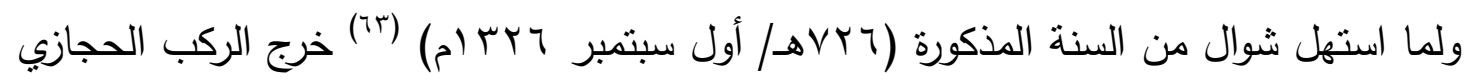

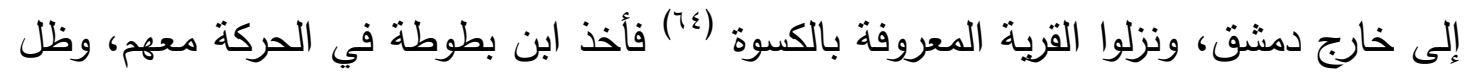
يتتقل من مرحلة إلى أخرى حتى وصل الحرم الثريف، وانتهي إلى المسجد النبوي الكريم بالمدينة

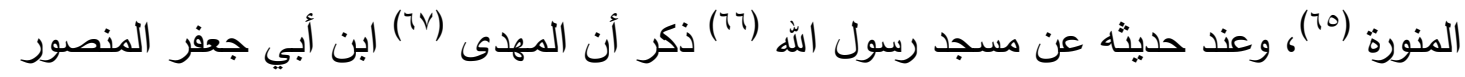

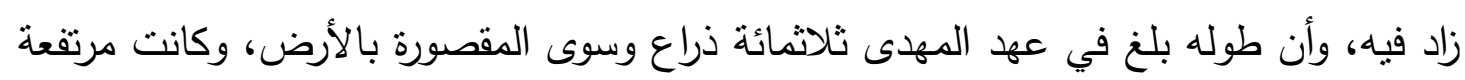

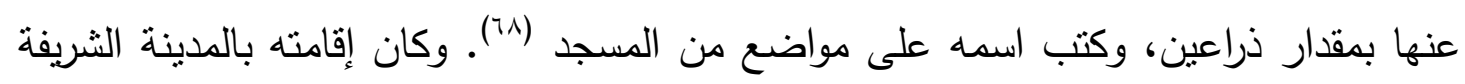

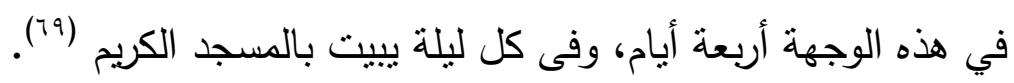

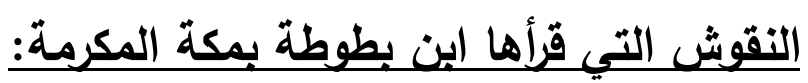
كان رحيل ابن بطوطة من المدينة، يريد مكة شرفهما الله، وبعد عدة مراحل وصل إلى البلد

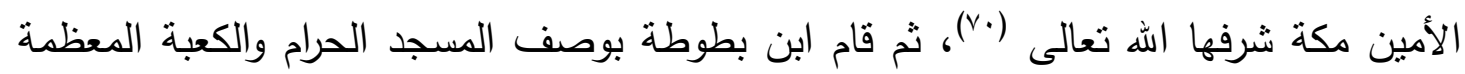

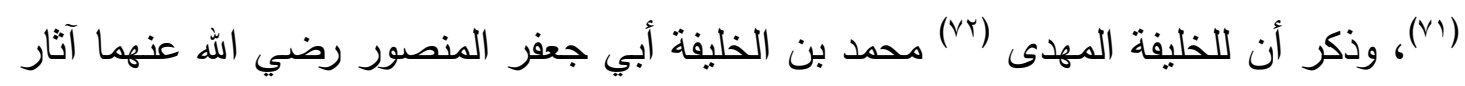

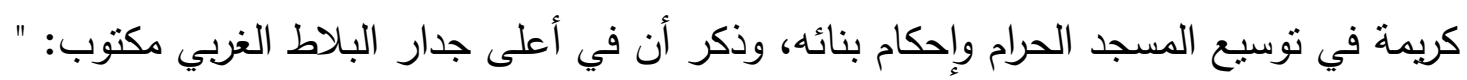

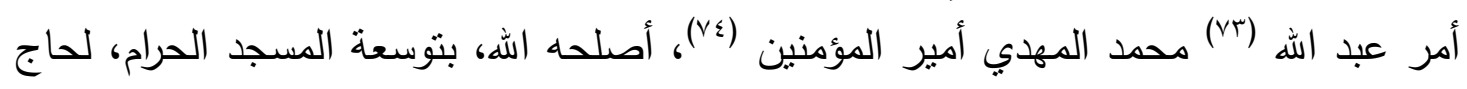

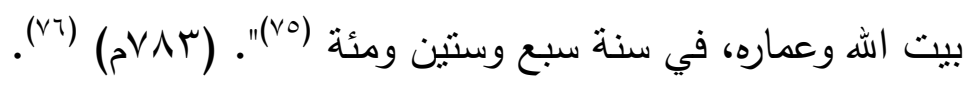

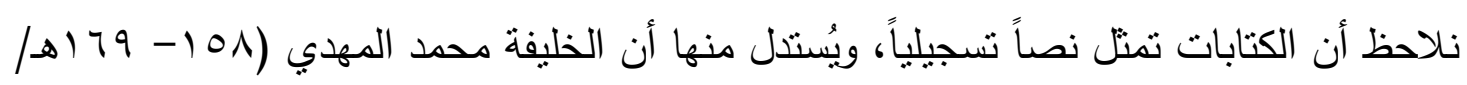

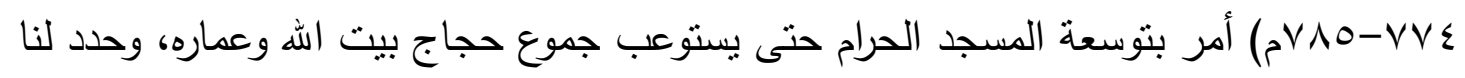

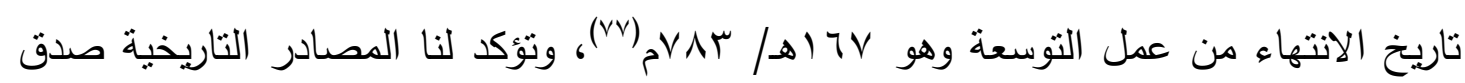

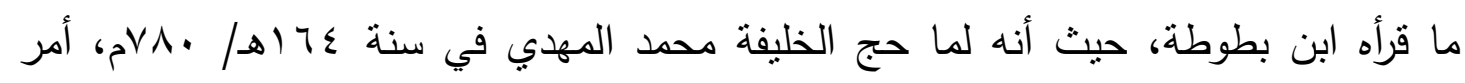

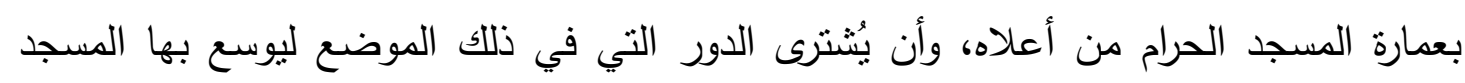

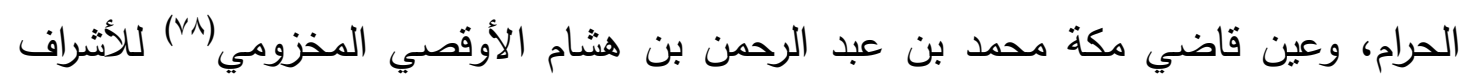


علي العمارة، فكان ثمن ما دخل في المسجد من ذلك كل ذراع مكسر بخمسة وعشرين ديناراً،

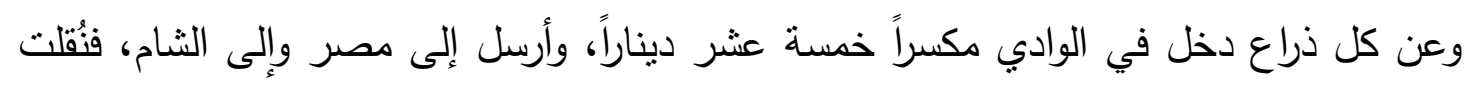

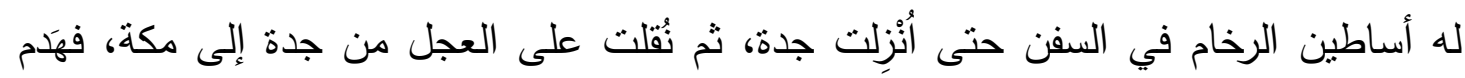

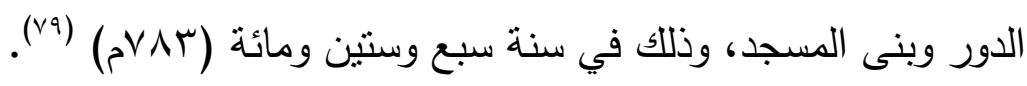

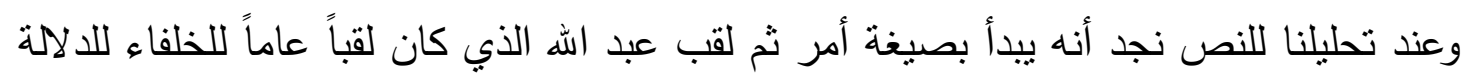

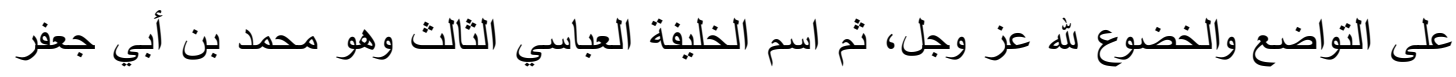

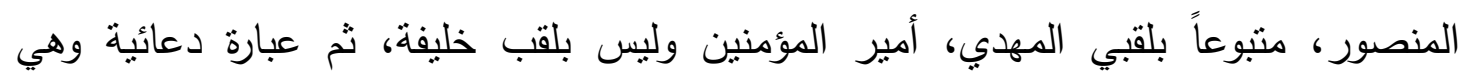

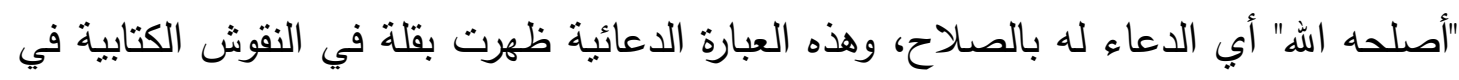

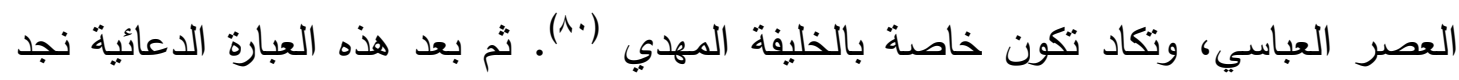

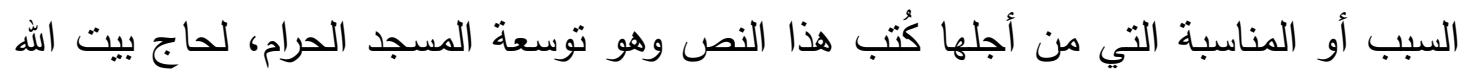

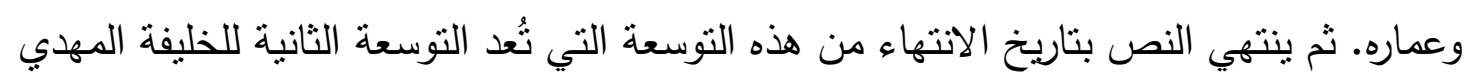

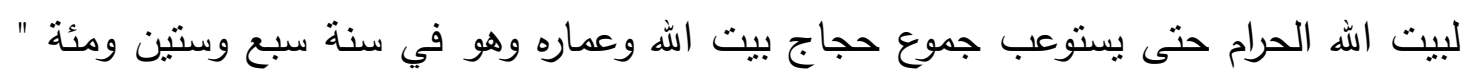
وهو ما أكدته لنا المصادر التاريخية. وعند ذكر ابن بطوطة للكعبة الثريفة ذكر أن ستور الكعبة الثريفة من الحرير الأسود مكتوب النابة

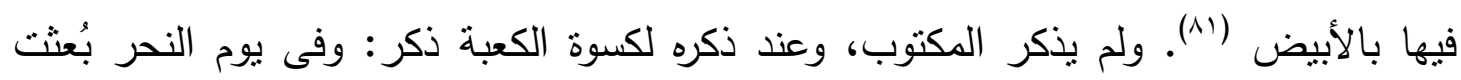

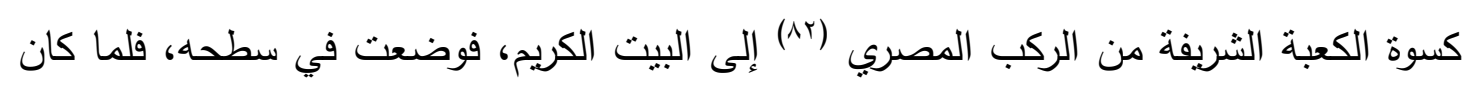

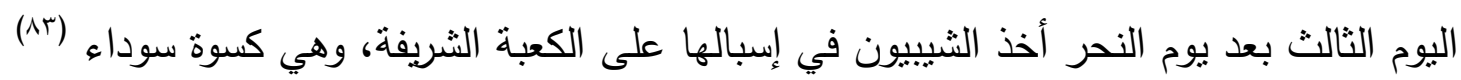

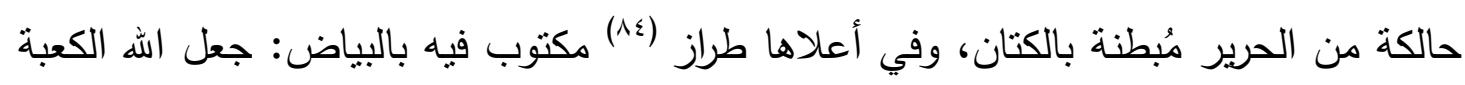

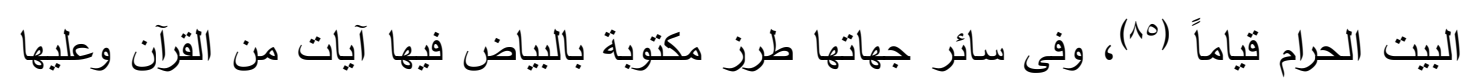
نور لائح مشرق من سوادها. وعند تحليلنا للنص نجد أنه عبارة عن جزء من آية قرأنية من سورة المائدة (آية وج). أما مدلول

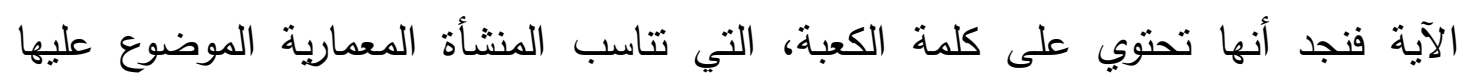
الكتابات.

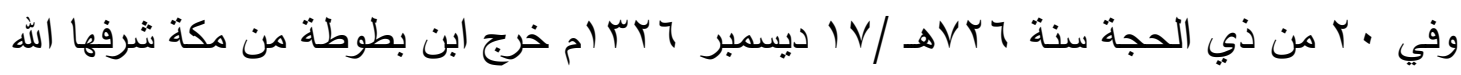

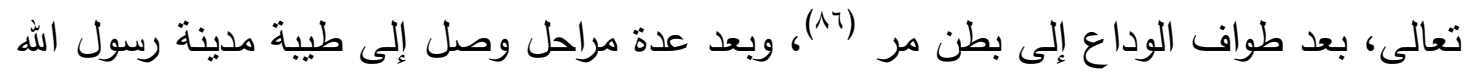

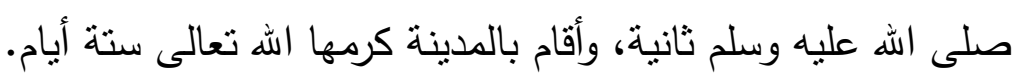




\section{النقوش التي قرأها ابن بطوطة بالعرلق:}

رحل ابن بطوطة عن المدينة المنورة، وظل بيتقل من مرحلة إلى أخرى حتى وصل مدينة مشهر

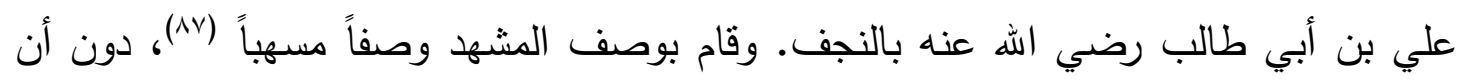

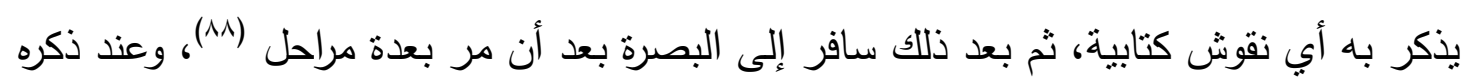

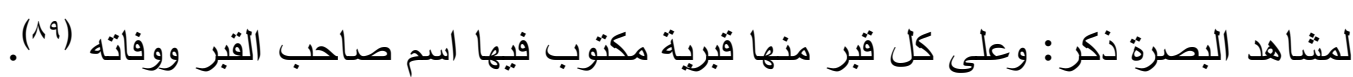

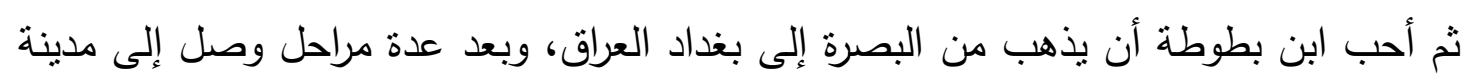

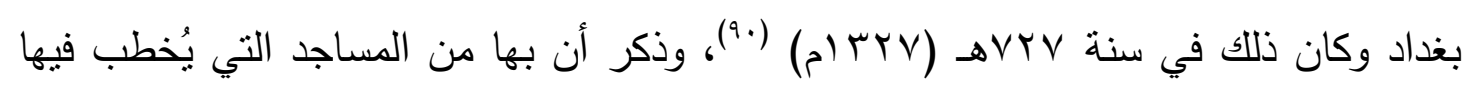

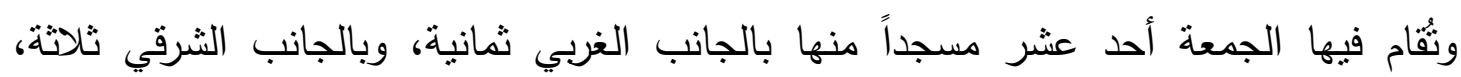

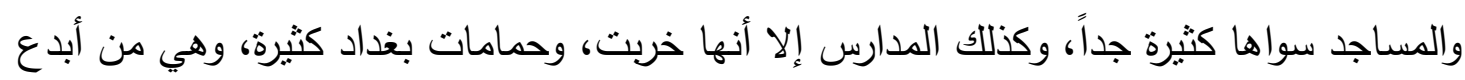

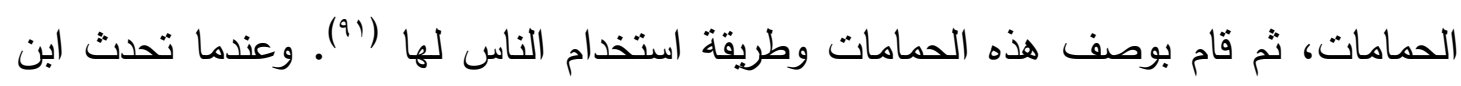

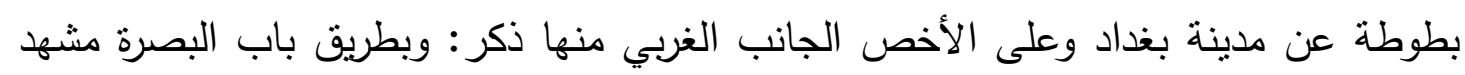

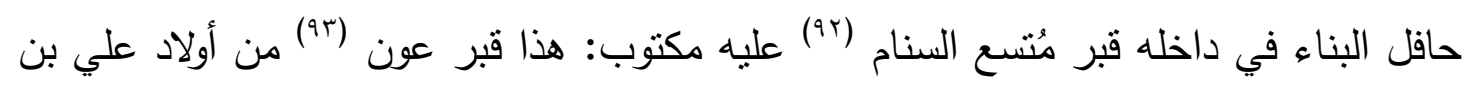

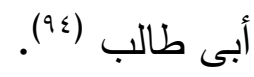

وعند تحليلنا للنص نجد أنه عبارة عن نص جنائزي يبدأ باسم الإثارة هذا وبعده الشئ المُشُار

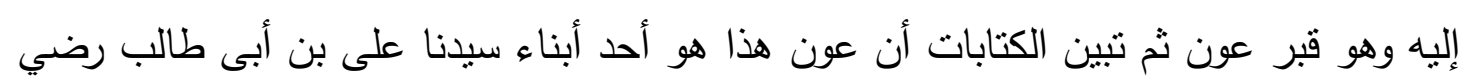

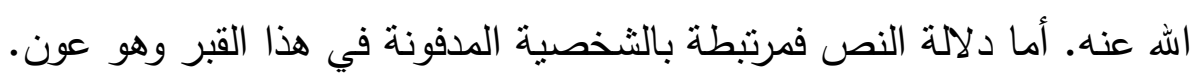

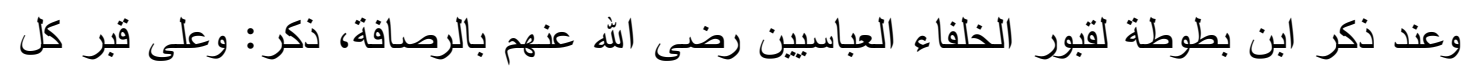

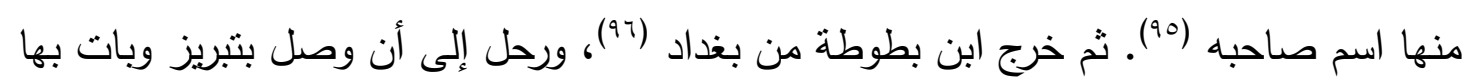

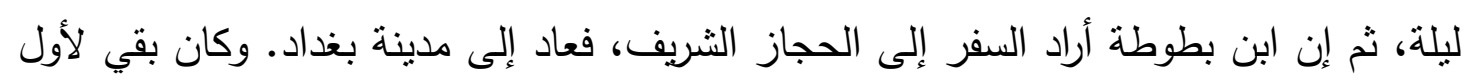

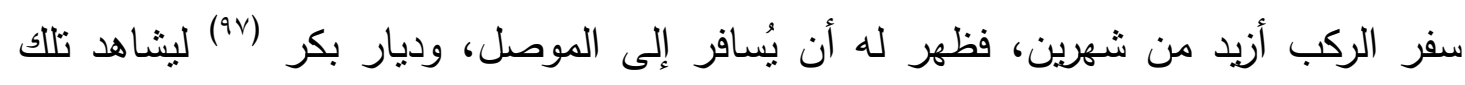

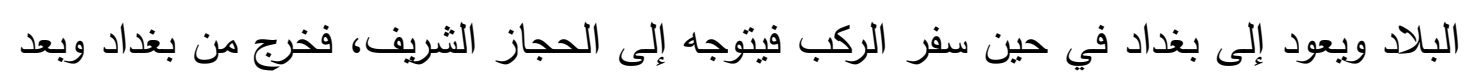

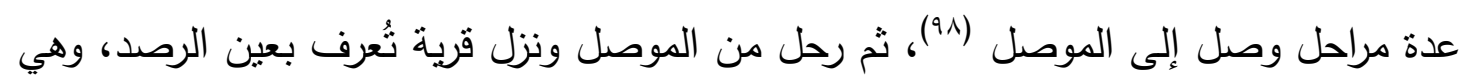

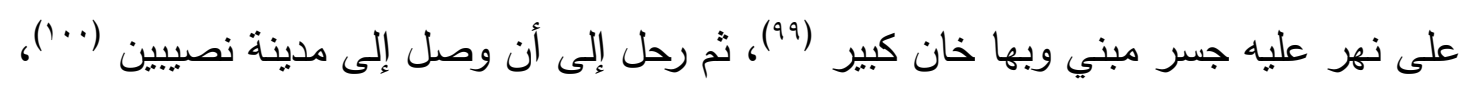

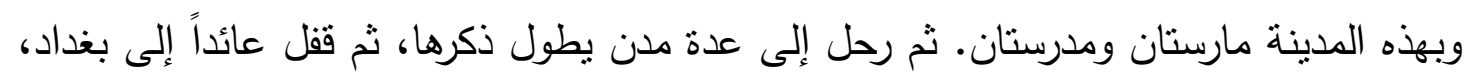

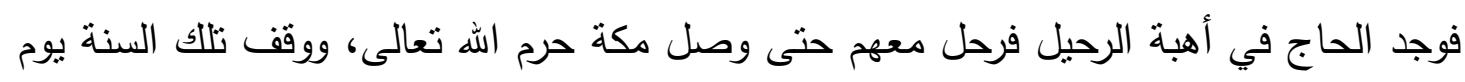

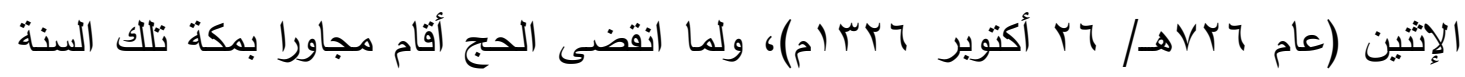

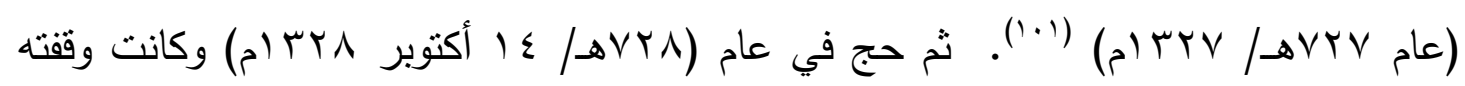

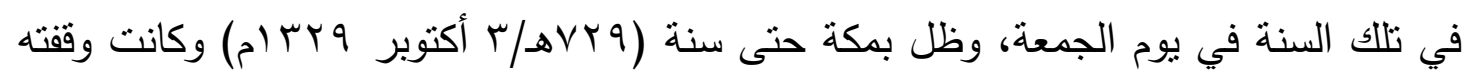


يوم الثلاثاء. ولما انقضى الحج اقام مجاورا بمكة حرسها الله سنة ثلاثين (وسبعمائة) (•rس (م)

\section{النقش الأي قرأه ابن بطوطة بالبمن:}

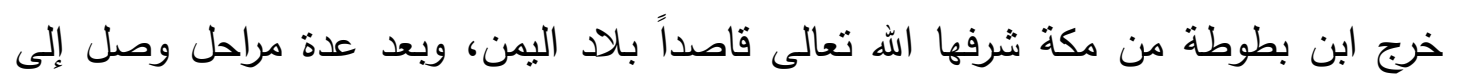

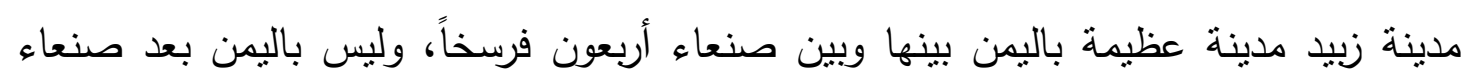

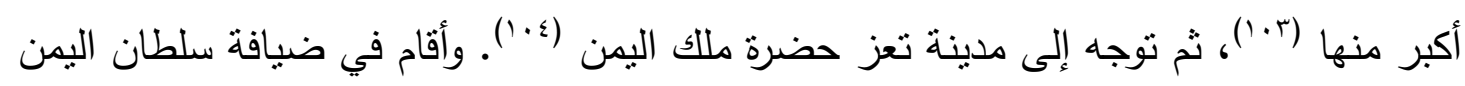

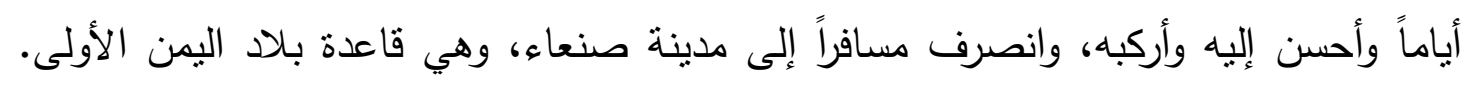

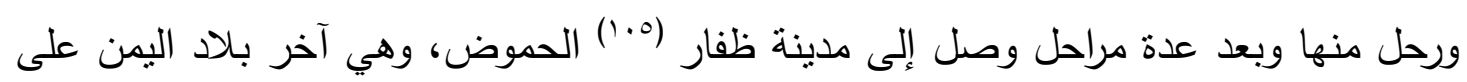

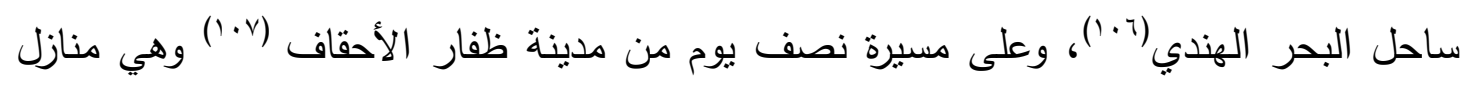

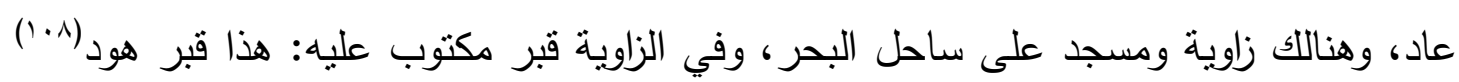
بن عابر عليه أفضل الصلاة والسلام (9. (1). وعند تحليلنا للنص نجد أنه عبارة عن نص جنائزي يبدأ باسم الإشارة هذا ثم بعدها الثئ المشار إليه وهو قبر هود بن عابر ثم عبارة دعائية عليه أفضل الصلاة والسلام.

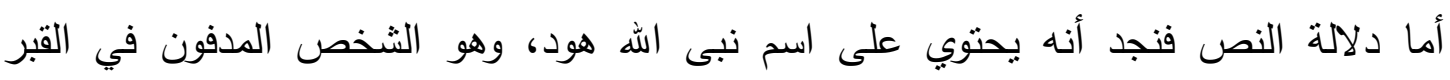
المحتوي على هذه الكتابات. ومن الأحقاف ركب ابن بطوطة البحر بريد عمان، وبعد عدة مراحل يطول ذكرها في هذا المقام

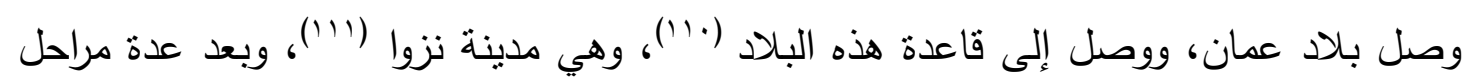

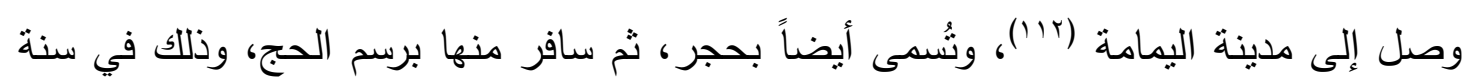

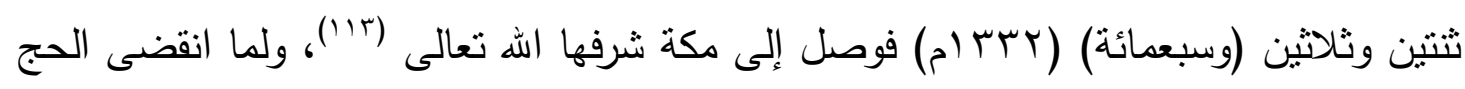

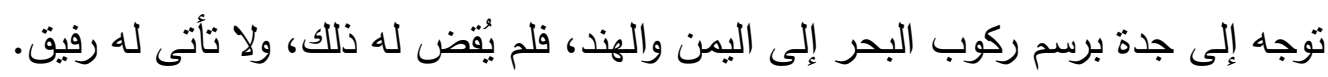

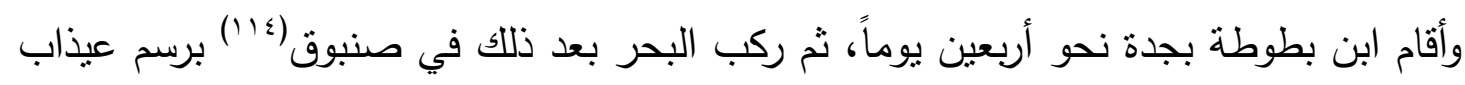

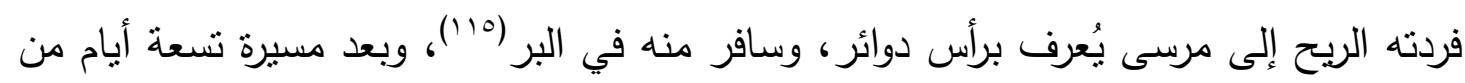

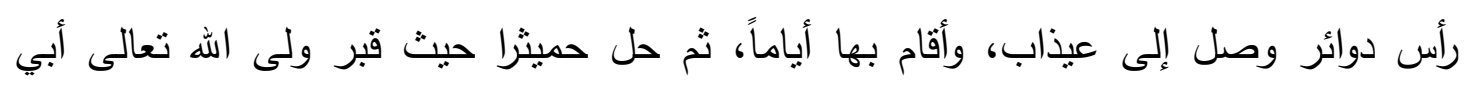

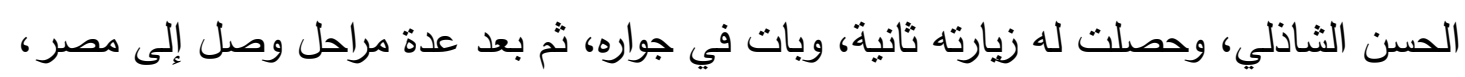

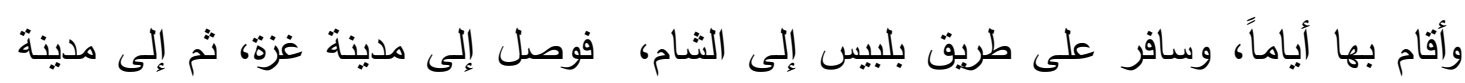

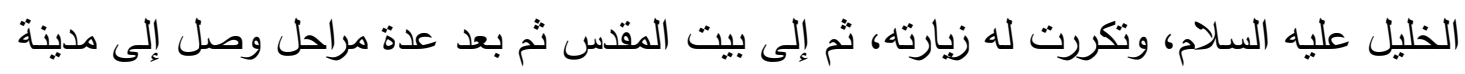

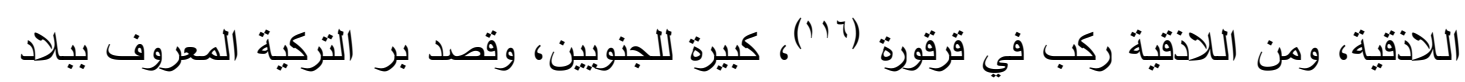

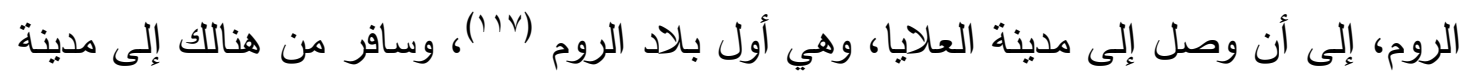


أنطاليا(1')، وبها مسجد جامع، ومدرسة، وحمامات كثثرة، وأسواق ضخمة مرنبة بأبدع ترتيب

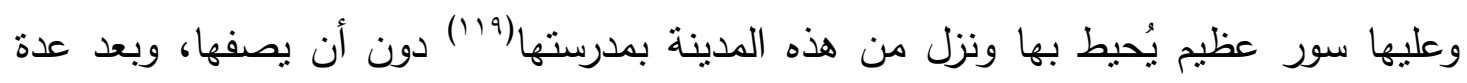

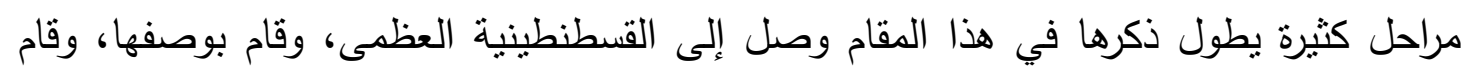
بذكر الكنيسة العظمى، وذكر المانسترات بها، وذكر أنها تشبه الزاوية عند المسلمين (.r').

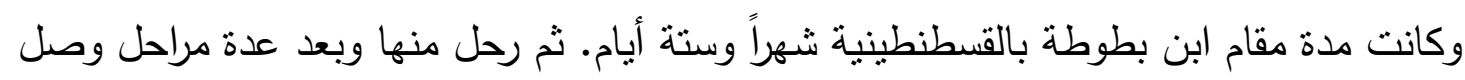

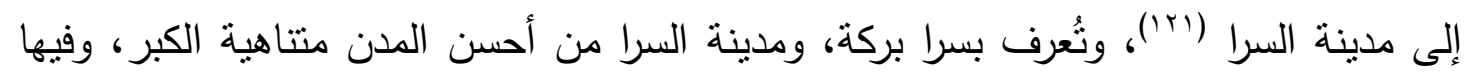

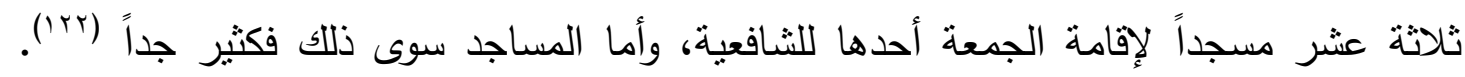

$$
\text { دون أن يصف لنا مسجداً واحداً. }
$$

\section{النقوش التي قرأها ابن بطوطة بيُخاري:}

سار ابن بطوطة من مدينة السرا وبعد عدة مراحل وصل إلى مدينة بُخاري، وهذه المدينة كانت

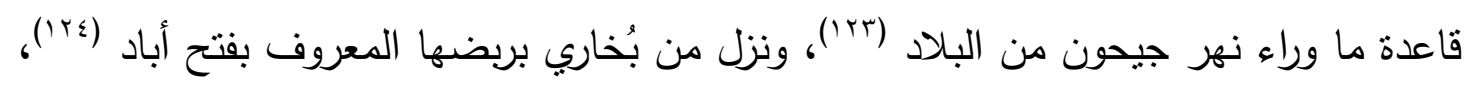

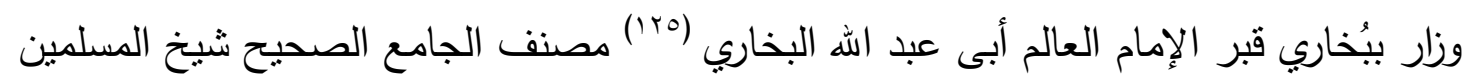

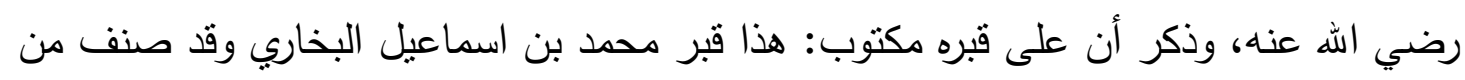

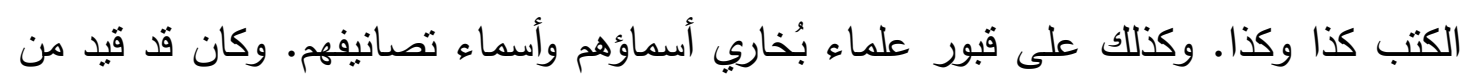

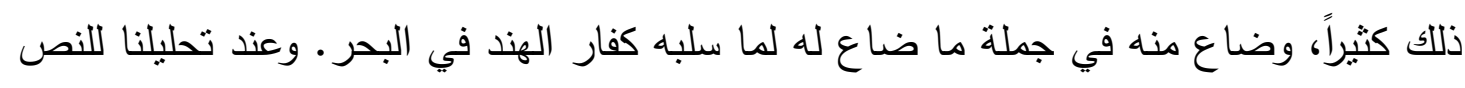

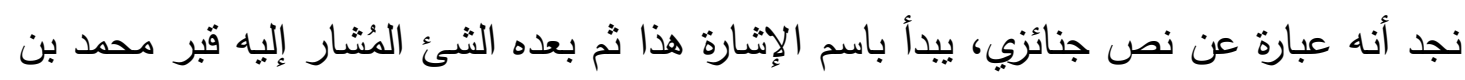
إسماعيل البخاري.

أما دلالة النص فتُعبر عن الثخص المدفون في القبر وهو الإمام البخاري.

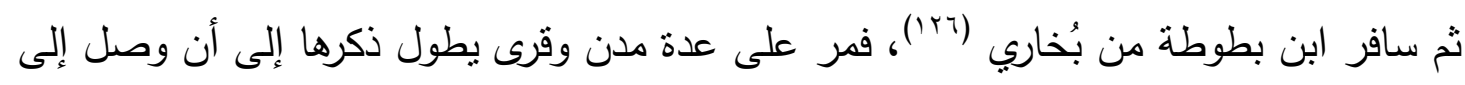

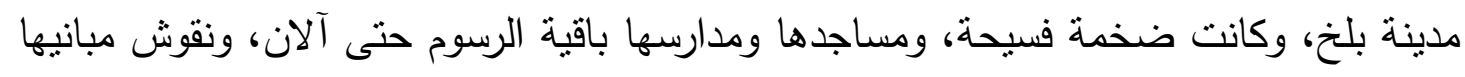

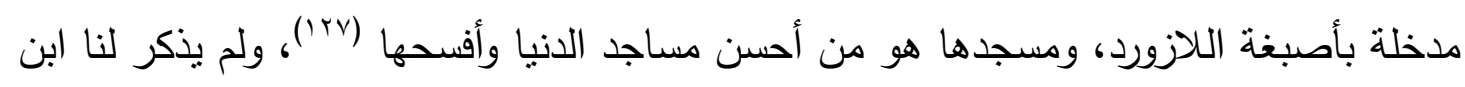
بطوطة أي نص كتابي سواء بمساجدها أو مدارسها، ثم سافر من مدينة بلخ إلى أن وصل إلى إلى إنى

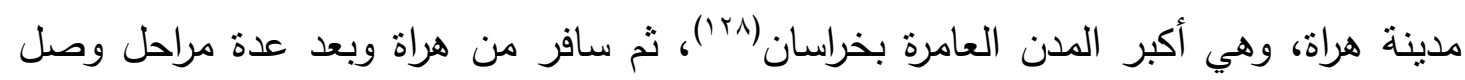

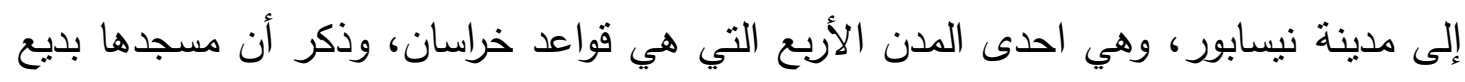

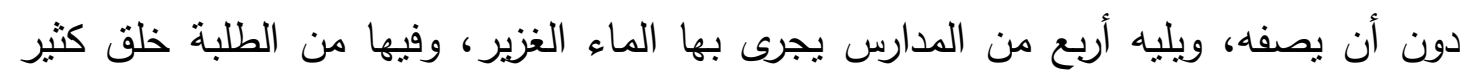

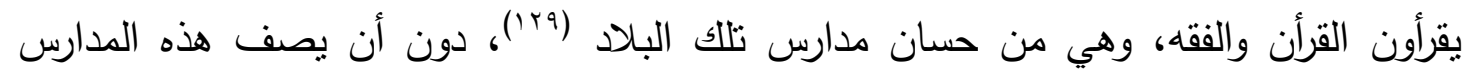
أيضناً. 


\section{النقوش التي قرأها ابن بطوطة بالهند:}

سافر ابن بطوطة من نيسابور، وبعد عدة مراحل وصل إلى بنج آب وهو ماء السند، وبنج معناه

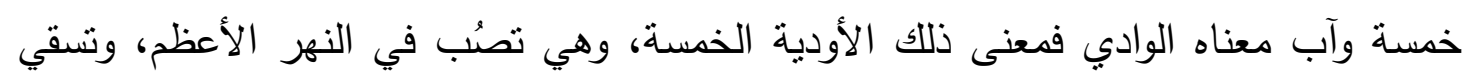
تلك النواحي (r.r)، وكان ذللك بتاريخ الغرة من شهر الله المحرم مفتتح عام أربعة وثثلاثين

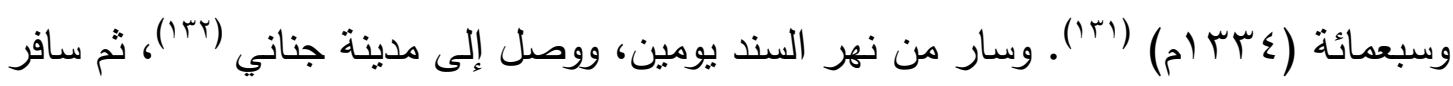

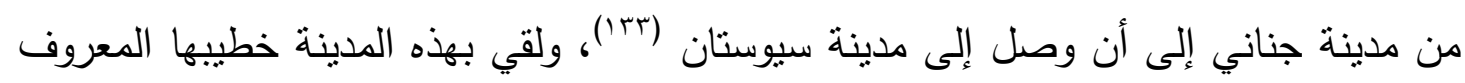

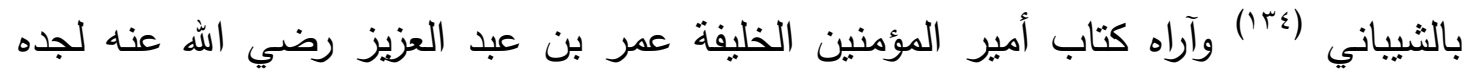

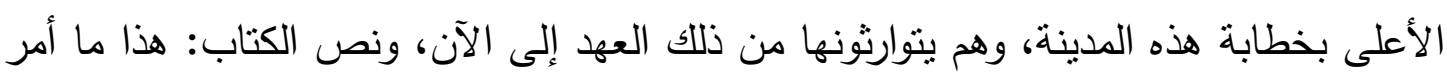

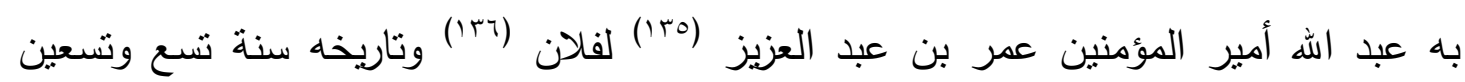
(

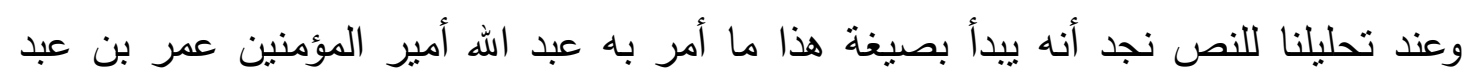

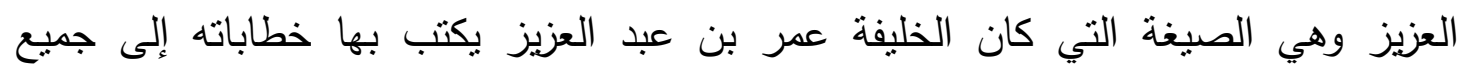

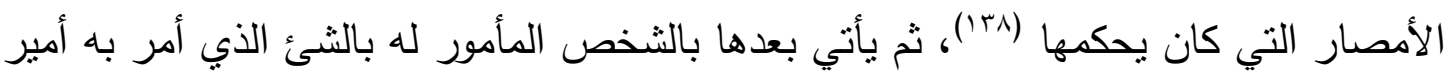

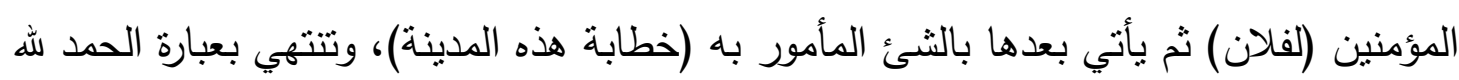

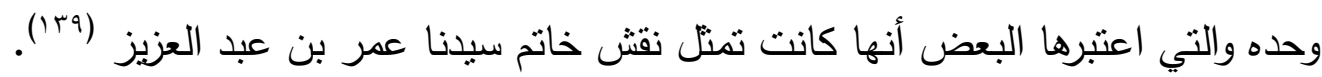

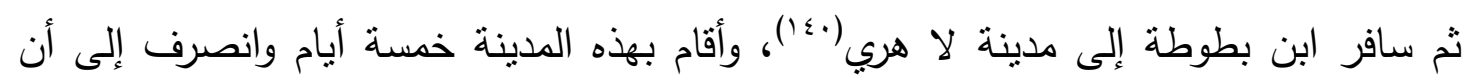

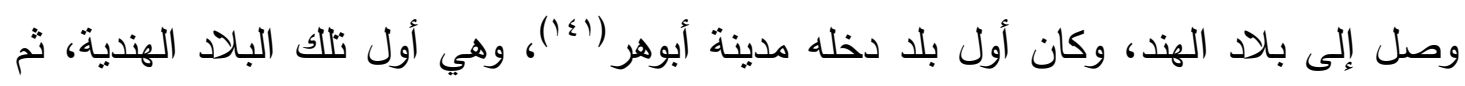

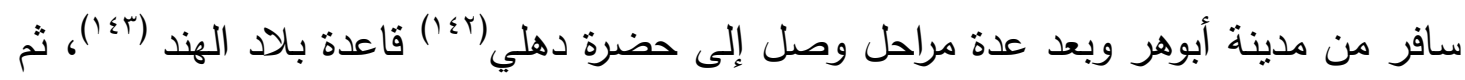

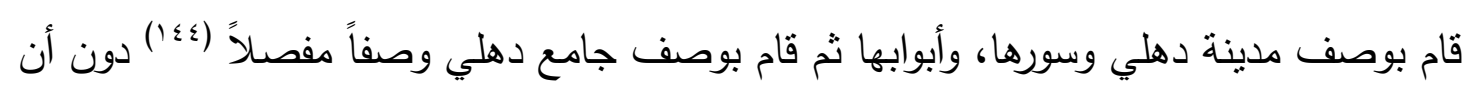

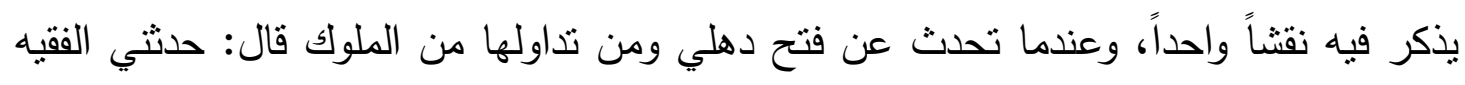

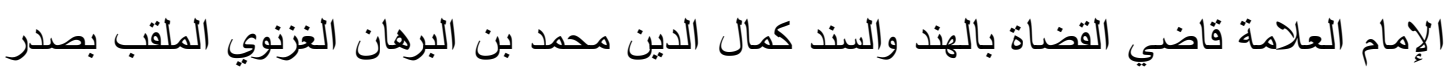

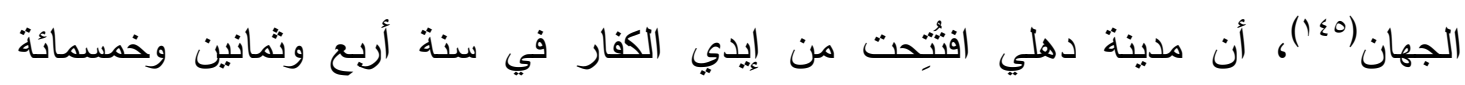

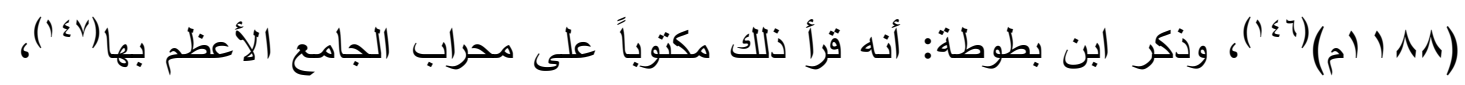
دون أن يأتي بالنص المكتوب. وعند ذكر ابن بطوطة للسلطان غياث الدين تُغلق شاه (يء (1) قال: ورأيتُ مكتوباً على مقصورة

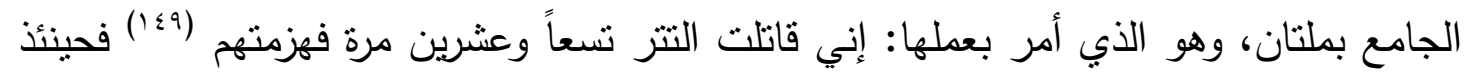

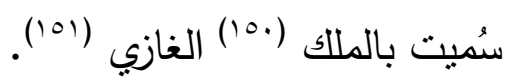


وعند تحليلنا للنص نجد أنه عبارة عن نص تذكاري يخبر أن السلطان غياث الدين تغلق قاتل

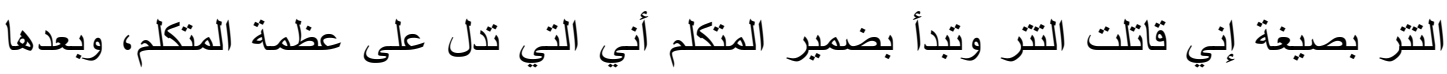

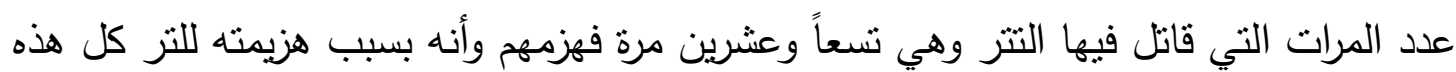
المرات سمى بالملاك الغازي. وهما لقبان لقب بهما السلطان غياث الدين تغلق.

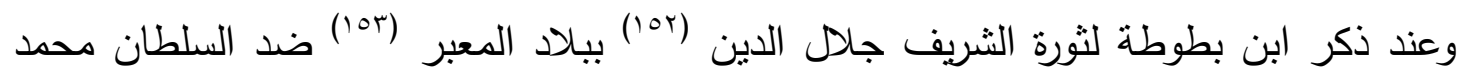

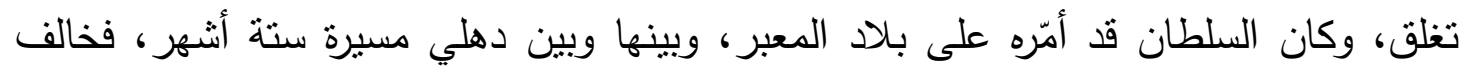
وادعى الملك لنفسه، وقتل نواب السلطان، وعماله وضرب الدنانير والدراهم باسمه، وكان يكتب دلب دلب

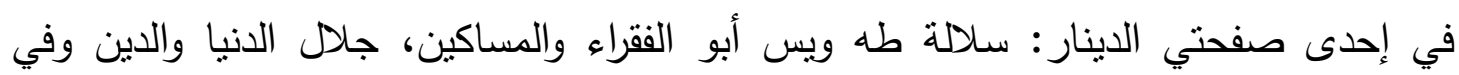

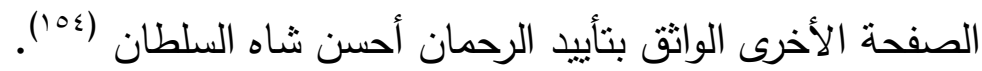
وعند تحليلنا للنص نجد أنه النص في أحد صفحتي الدينار (الوجه) يبدأ بعبارة سلالة طه ويس الونس إي أنه من سلالة النبي صلى اله عليه وسلم لأن طه ويس اسمان من أسماء النبي صلى الله عليه وسلم، ثم بعدها لقب أبو الفقراء والمساكين، ومعنى اللقب كافل الفقراء والدساكين، والتعبير

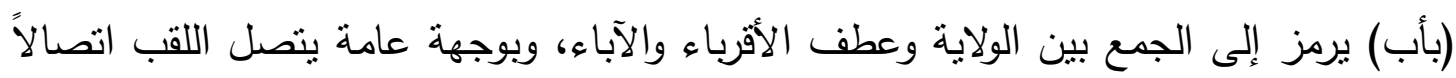

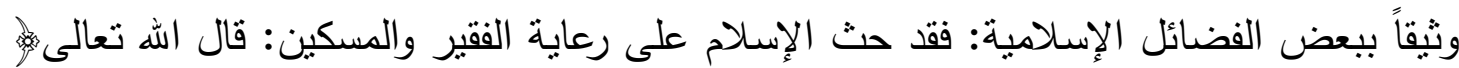
إن تندوا الصدقات فنعما هي وإن تخفوها وتؤتوها الفقراء فهو خير لكم ويكفر عنكم من سيئاتكم

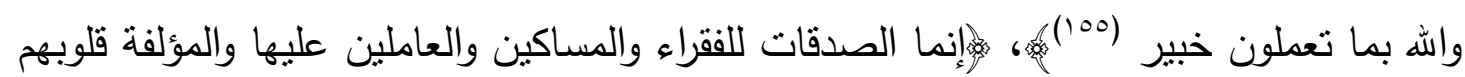

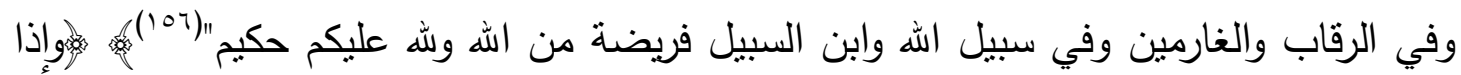

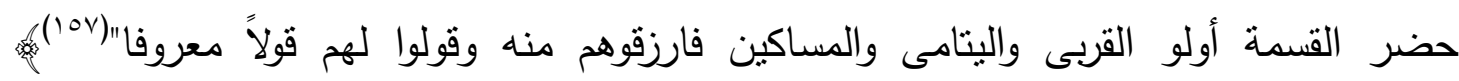

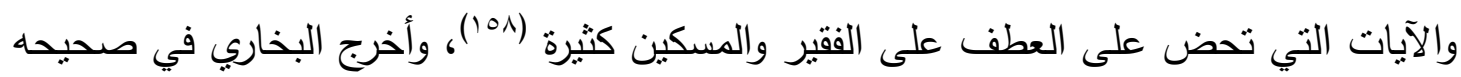
عن أبي هريرة رضي الله عنه قال: قال النبي صلى الله عليه وسلم الالساعي على الأرملة

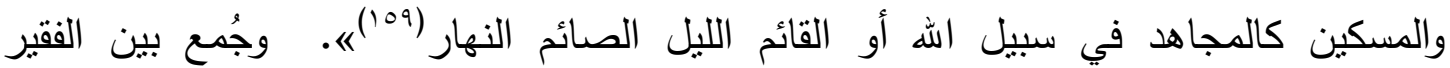
والمسكين في هذا اللقب لأن كليهما ضعيف يحتاج إلى من يحيمه ويرد عنه العدوان (17).

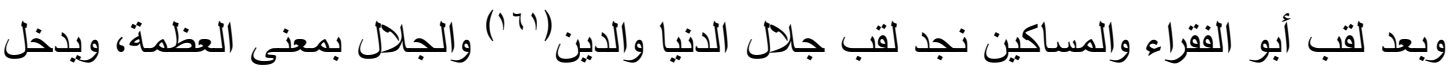

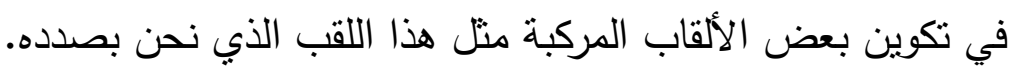
أما الصفحة الأخرى من الدينار (الظهر) فتتنمل على الواثث بتأييد الرحمان أحسن شاه السلطان.

وعند تحليلنا للنص نجد أن يشتمل على عدة ألقاب منها الواثِق بتأيبد الرحمان والواثق اسم فاعل

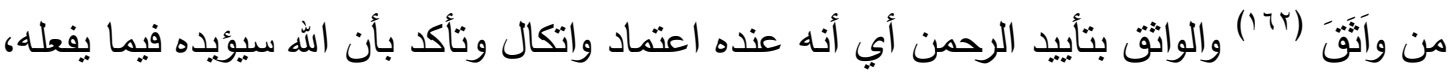


والرحمن اسم من أسماء اله عز وجل، وبعده لقب مركب أحسن شاه، وأحسن بمعنى الأفضل

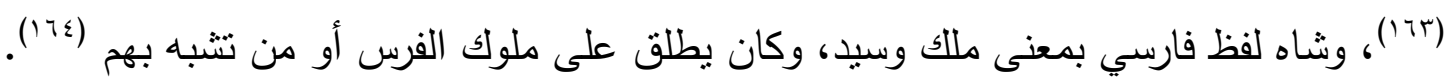
وبعدها لقب السلطان (170). ثم طلب ابن بطوطة من السلطان محمد تغلق الأذن في السفر إلى الحجاز، فأذن له فيه

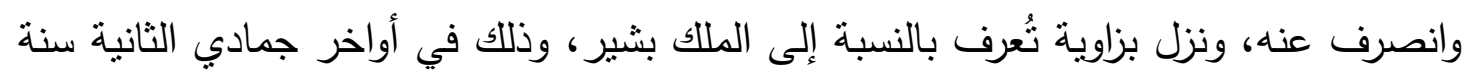

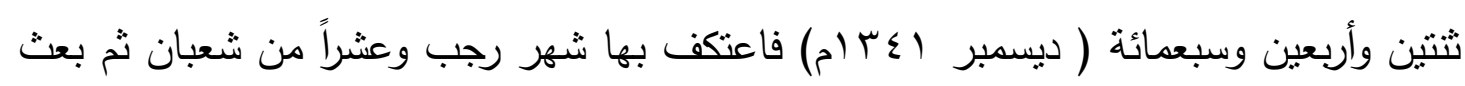

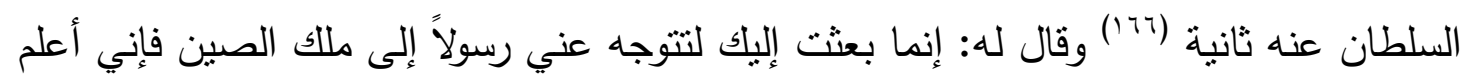

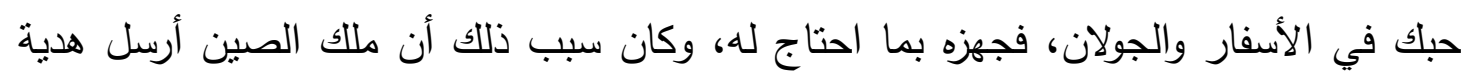

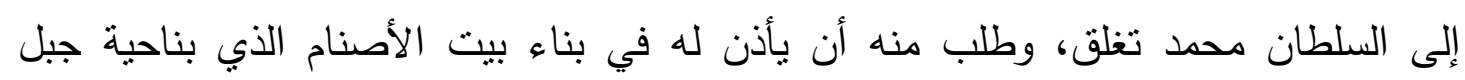

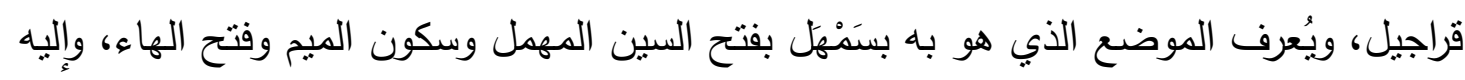

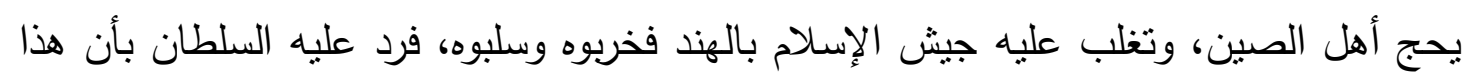

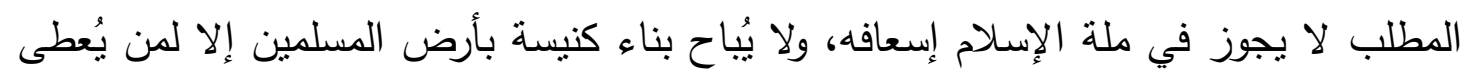

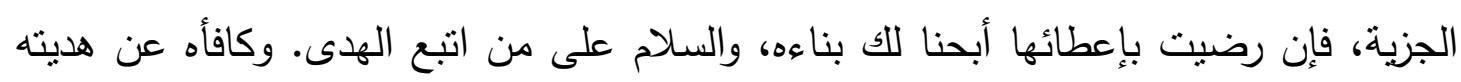
بخير منها (1TV) وسافر ابن بطوطة في السابع عشر لثهر صفر سنة ثلاث وأربعين (وسبعمائة) (الثاني

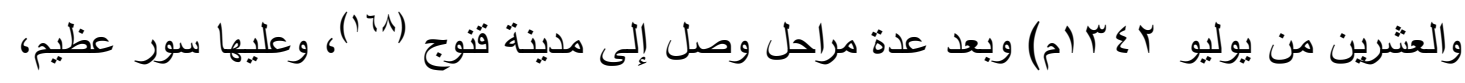

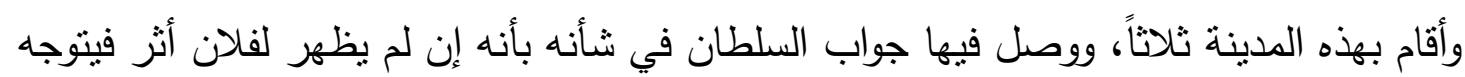

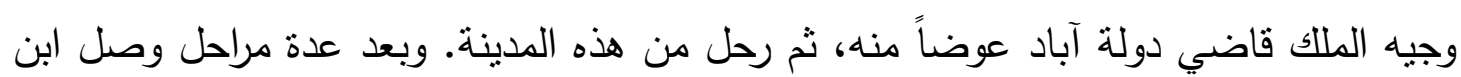

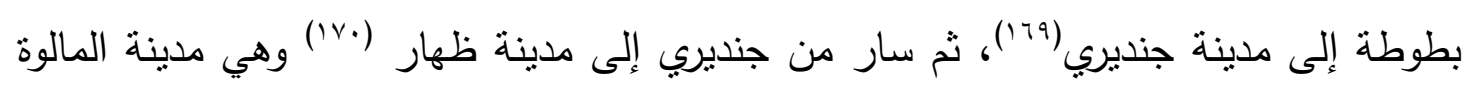
أكبر عمالة تلك البلاد، وبينها وبين دهلي أربعة وعشرون يوماً، وعلى الطريق بينهما أعمدة

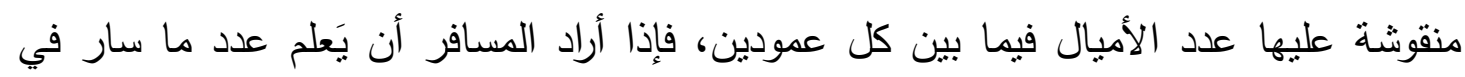

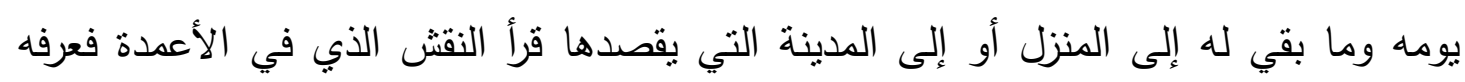

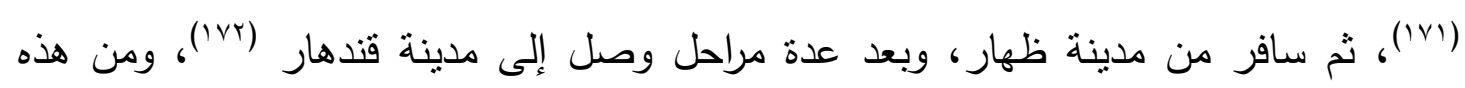

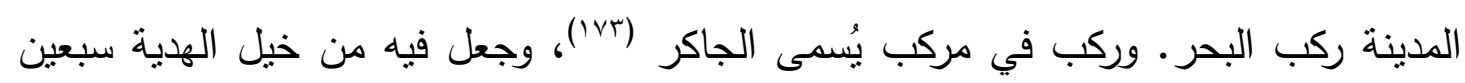
فرساً (1Vا)، وبعد عدة مراحل وصل إلى مدينة هنور (1vo)، ورأي بالمدينة ثلاثة عشر مكتباً لتعليم

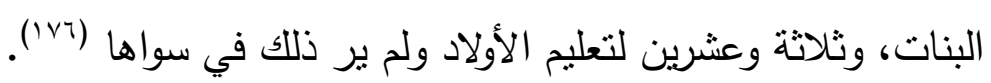

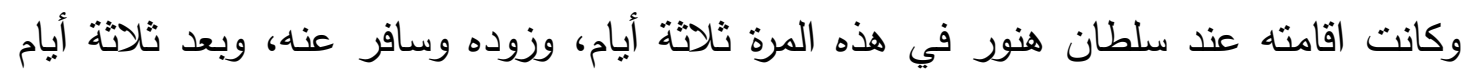

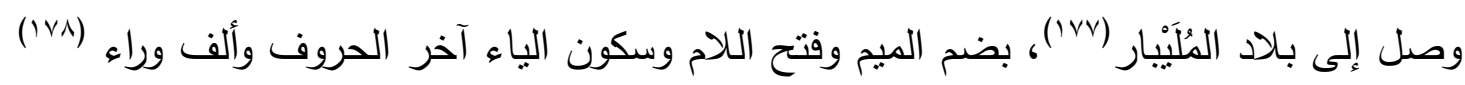




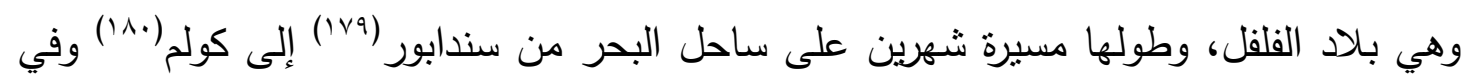

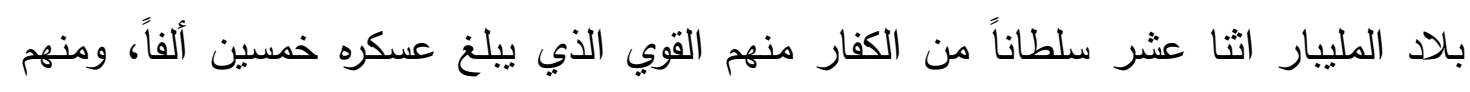

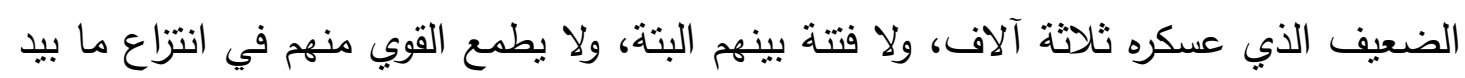

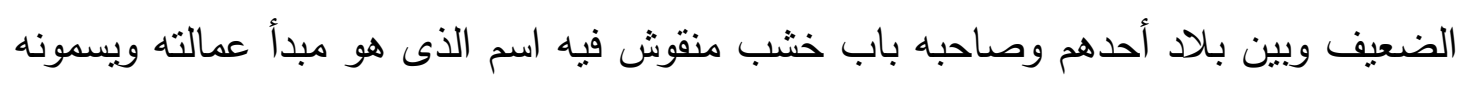

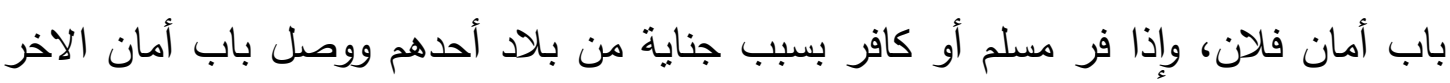

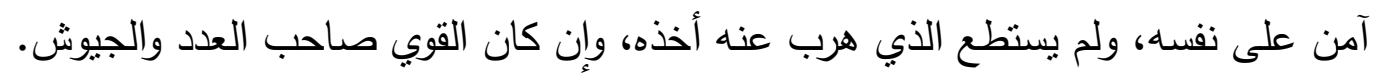

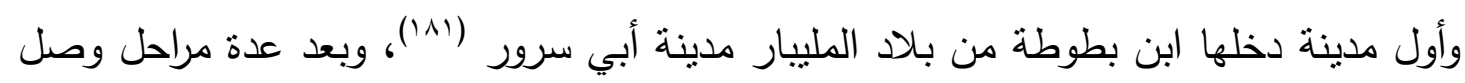

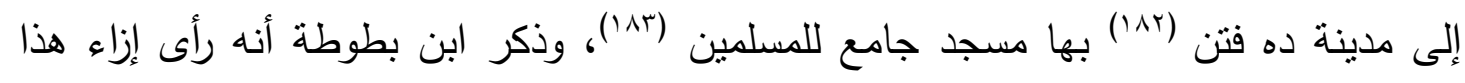

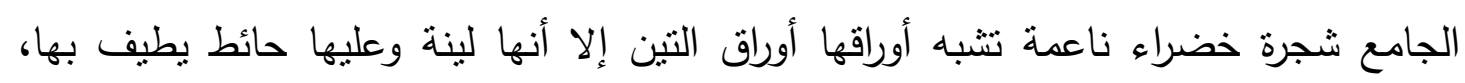
وعنده محراب صلي فيه ركعتين، واسم هذه الثجرة عندهم دَرَخْت الثهادة، ودَرَخْت بفتح الدال

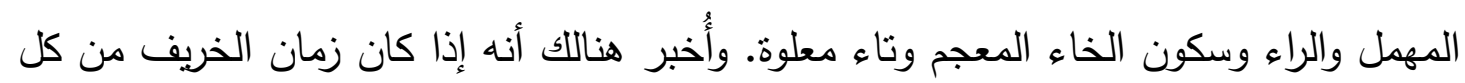

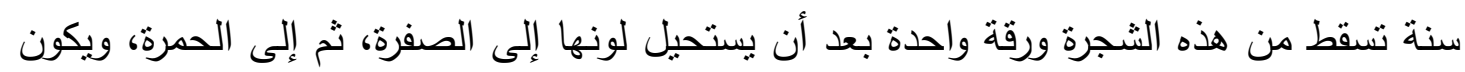

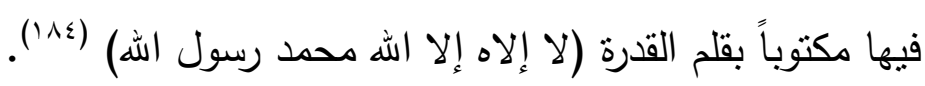
ثم سافر ابن بطوطة إلى مدينة بدفتن (101)، وهي مدينة كبيرة وبخارجها مسجد بمقربة من البحر

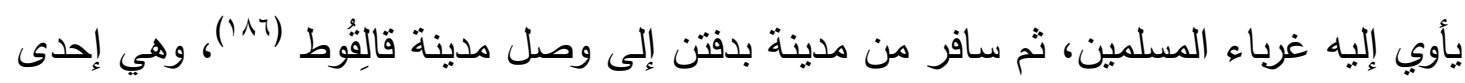

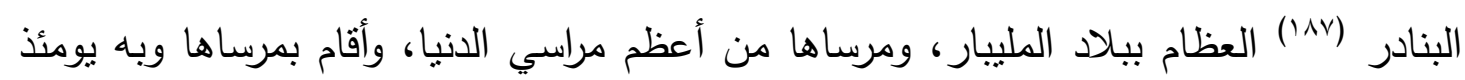

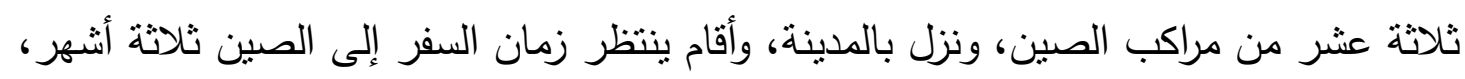
وبحر الصين لا يُسافر فيه إلا بمراكب الصين. ولما حان وقت السفر إلى الصين تم تجهيز جنيكاً

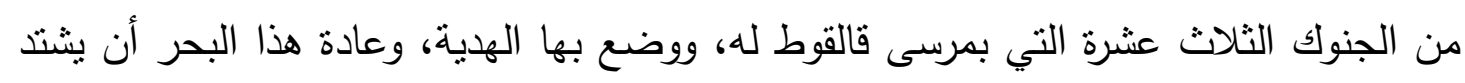
هيجانه كل يوم بعد العصر فلا يسنطيع أحد ركوبه، ورمى البحر بالجنك الذي كانت فيه الهدية فمات جميع من فيه (1) (1). وركب ابن بطوطة مركباً آخر غير الجنك السابق فوصل في اليوم العاشر من سفره إلى مدينة

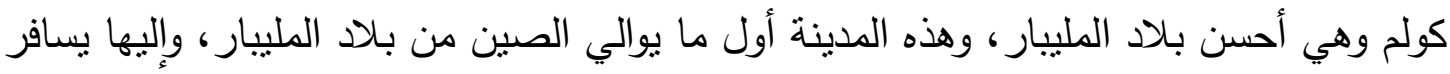

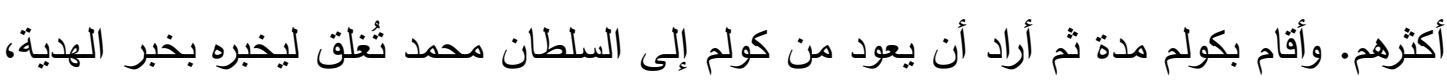

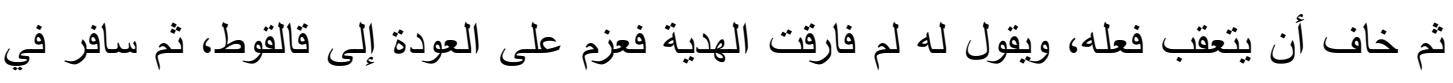

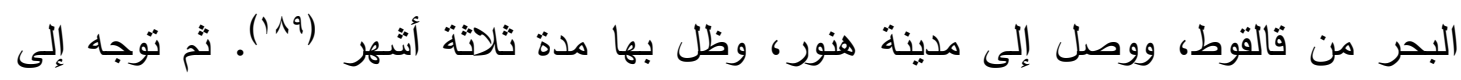

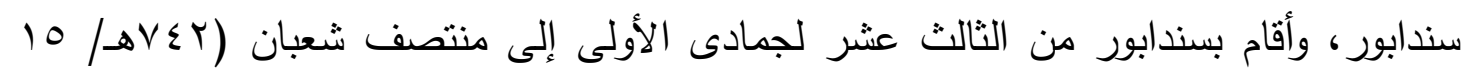

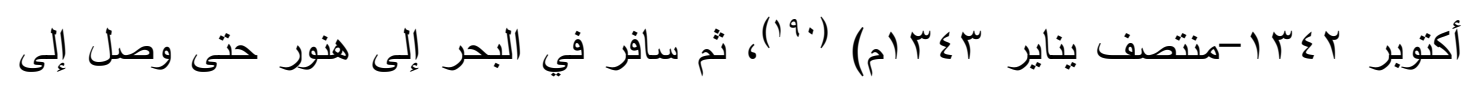


مدينة الثناليات (191)، واقام بها فطال مقامه فعاد إلى قالقوط، ثم إلى هنور، ثم إلى سندابور

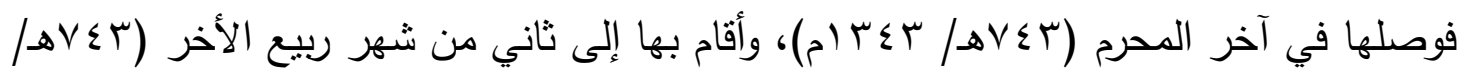

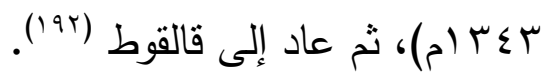

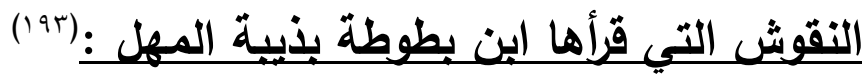

عزم ابن بطوطة على السفر إلى ذيبة المهل، وكان يسمع بأخبارها فبعد عشرة أيام من ركوبه

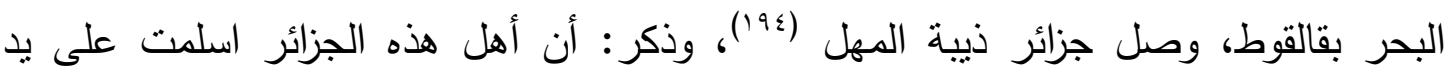

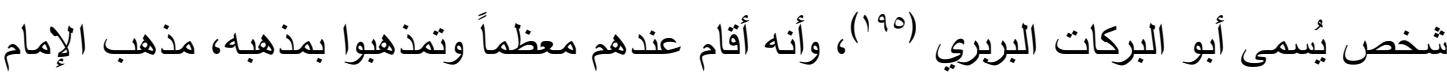
مالك رضي الله عنه، وهم إلى هذا العهذ يعظمون المغاربة بسببه، وبنى مسجداً بها معروفاً

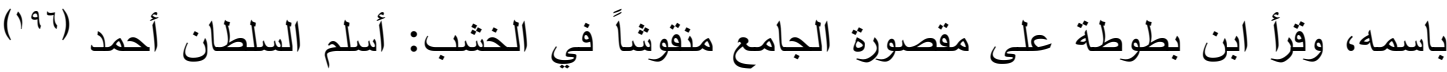

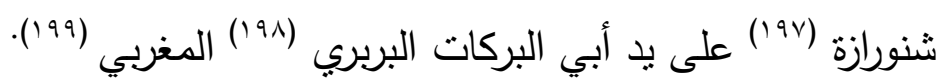
وعند تحليلنا للنص نجد أنه عبارة عن نص تذكاري يُشير إلى تاريخ إسلام سلطان جزر المالديف

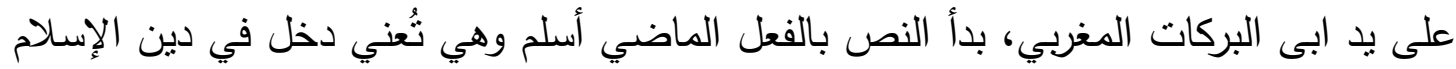

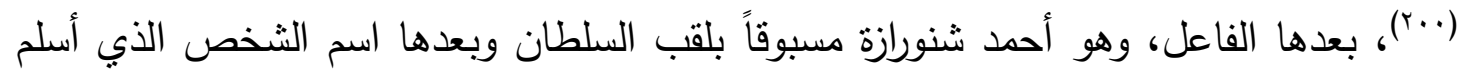
السلطان على يديه، وهو أبي البركات البربري المغربي. ويستخل من اسمه أنه من بلاد المغرب.

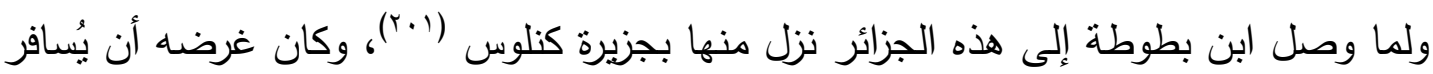

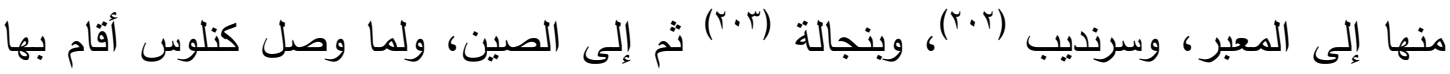

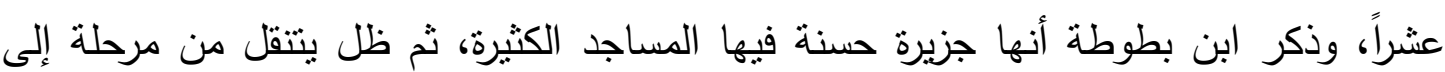
أخرى حتى وصل إلى بلاد الصين (\&.r)، وكانت أول مدينة وصل فئل إليها مدينة الزينون، وهذه

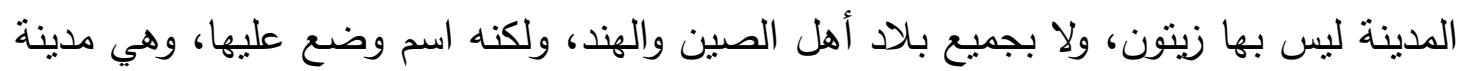

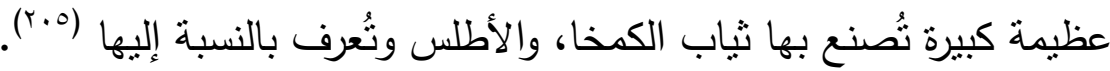

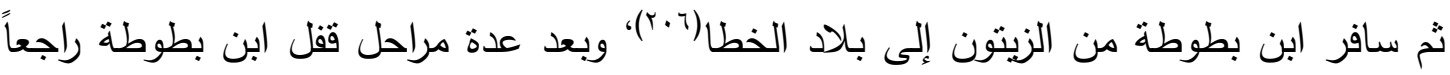

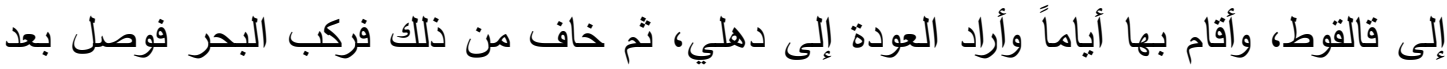

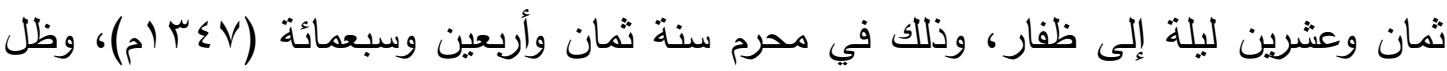
يتتقل من مرحلة إلى أخرى حتى وصل إلى جدة، ثم سافر منها إلى مكة شرفها الله تعالى وكرمها

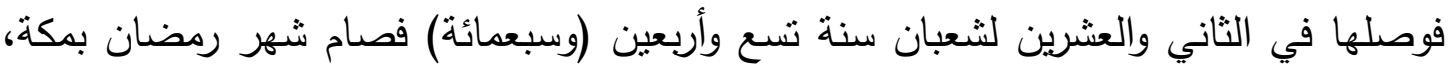

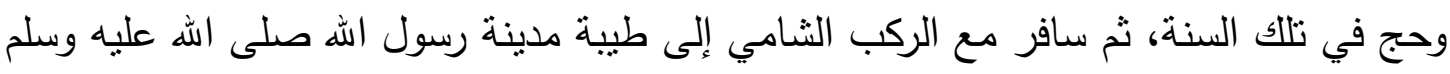

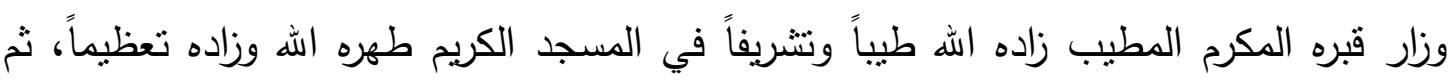

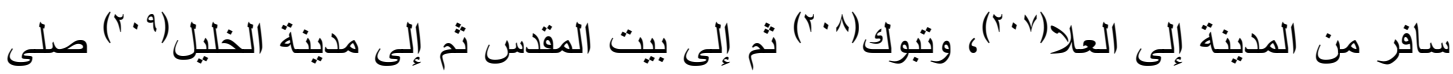


الله عليه وسلم، ثم إلى غزة ثم إلى منازل الرمل، وقد تقدم ذكر كله، ثم إلى القاهرة. ثم ركب

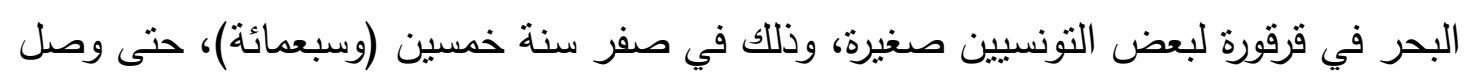

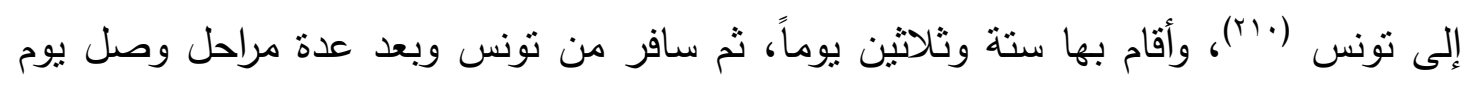

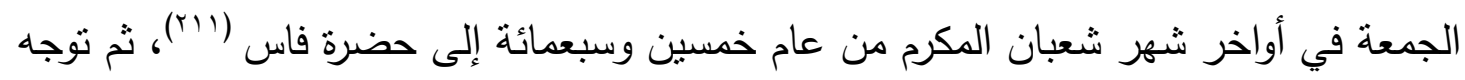

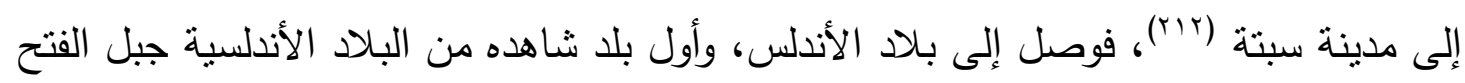

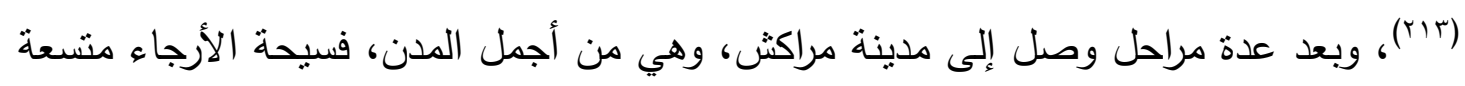

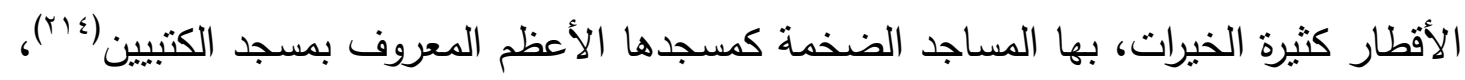

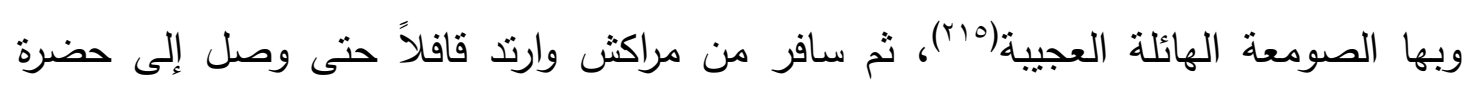

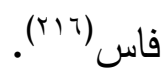




\section{نتائج البحث:}

1.اهتم ابن بطوطة بالنقوش، واعتبرها مصدراً من مصادر رحلته، وسجل الكثير من هذه

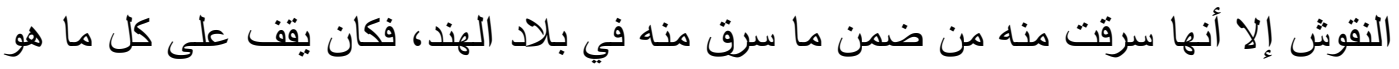
مكتوب على لوحة خشبية أو قطعة من حجر أو رخام ويسجلها ويحفظها، وقد أمست بالنسبة لنا اليوم بمثابة وثيقة حيث تؤكد ما كان برويه الرجل قبل نحو من سبعة قرون.

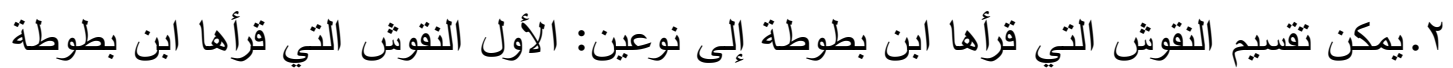

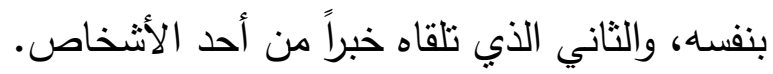
r.ناحظ أن خلفية ابن بطوطة الدينية وحبه للتصوف والمتصوفين آترت على قرآته للنقوش التشاهي فكان مهتماً أكثر بالنقوش على القبور وشواهدها.

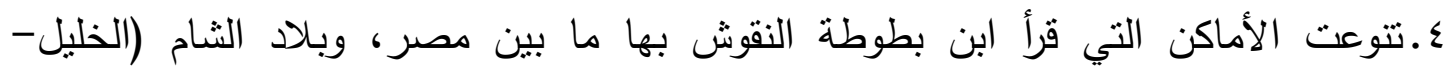

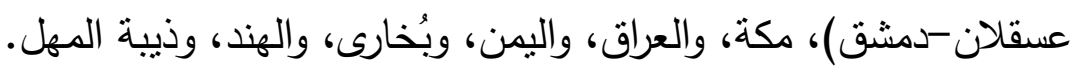

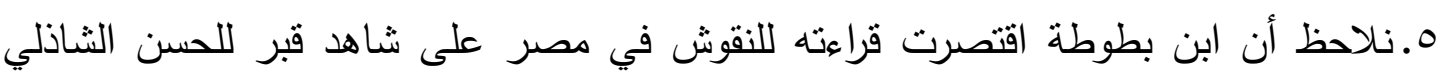

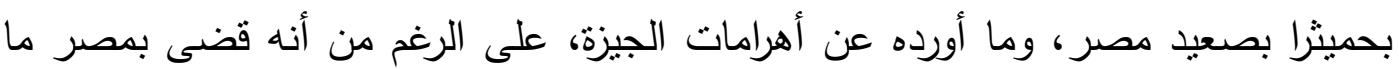

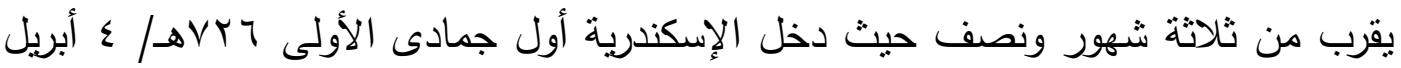

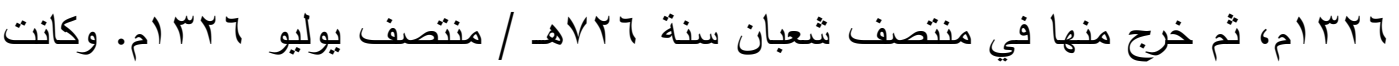

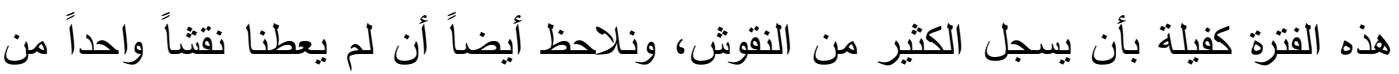
العصر المملوكي على الرغم من دخوله مصر في عهد الملك الناصر محمد بن قلاوون.

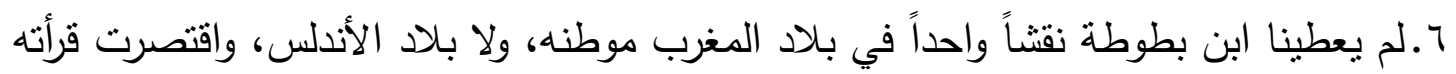

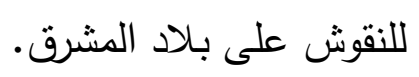

V.حازت بلاد الثام والهند النصيب الأكبر من النقوش التي قرأها ابن بطوطة بها حيث بلغت

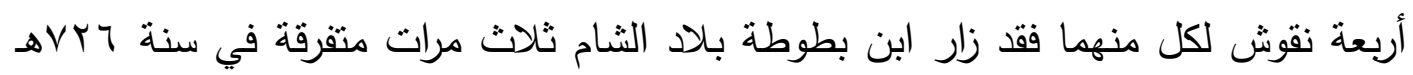
و TrYهـ و و

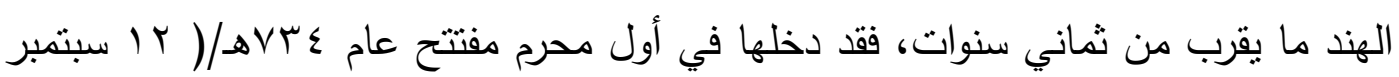

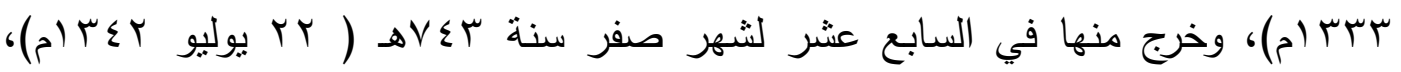
وبعدها مصر ، ومكة المكرمة حيث اقتصرت كل منهما على نقتشين، واقتصر العراق، واليمن، وبخارى، وذيبة المهل على نقش واحد لكل منهم.

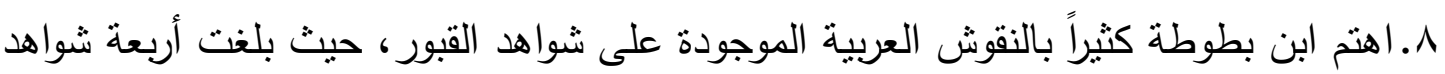

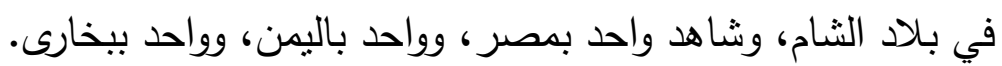


9. نتوعت الكتابات التي قرأها ابن بطوطة ما بين آيات قرأنية مثل بسم اله الرحمن الرحبم، كما

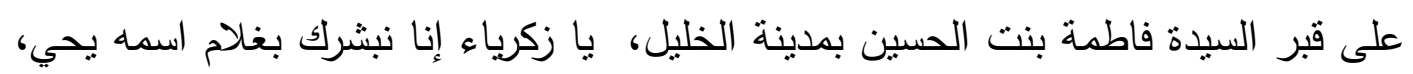

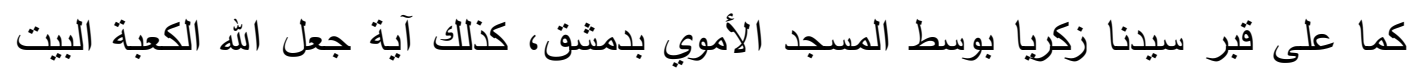

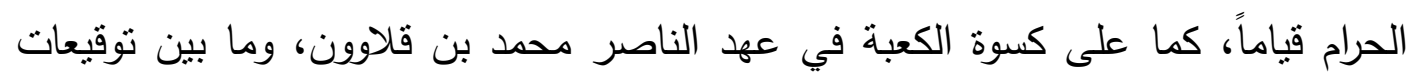
للصناع صنعه محمد بن أبي سهل النقاش بمصر ، كما على على قبر السيدة فاطمة بنت الحسين

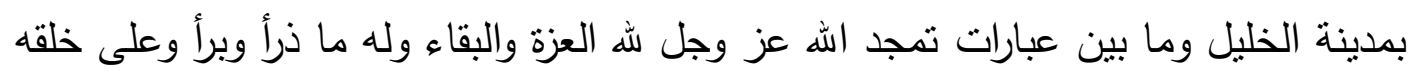
كتب الفناء، كما على قبر السيدة فاطمة بنت الحسين بمدينة الخليل، وما بين عبارات دعائية منل رضي الله عنه، كما على قبر السيدة فاطمة بنت الحسين بمدينة الخليل و صلى الله

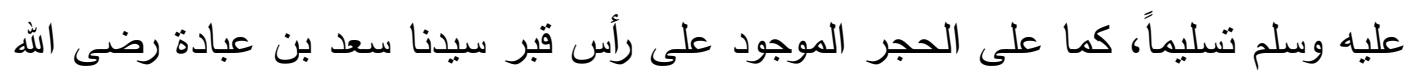

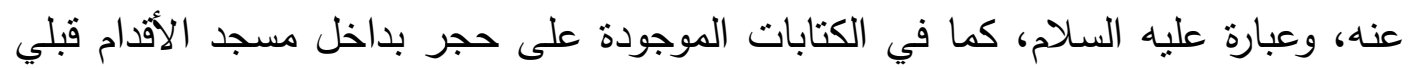

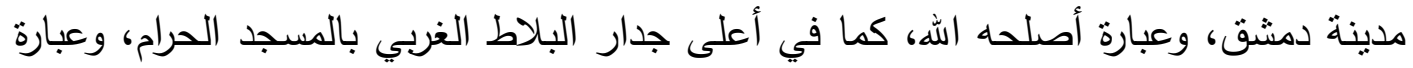

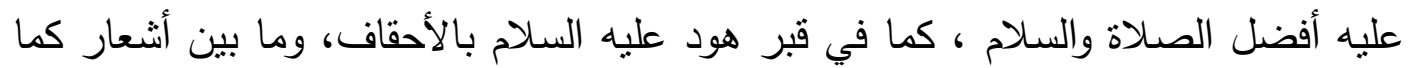
على قبر السيدة فاطمة بنت الحسين بمدينة الخليل، وما بين شهادة التوحيد (لا إلاه إلا الهه

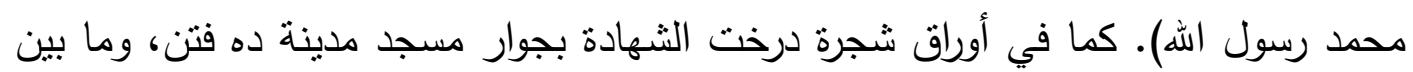

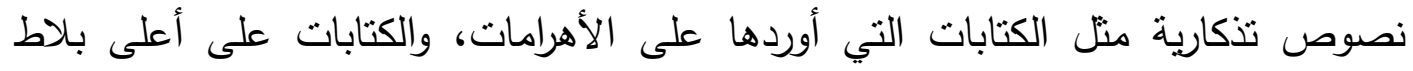

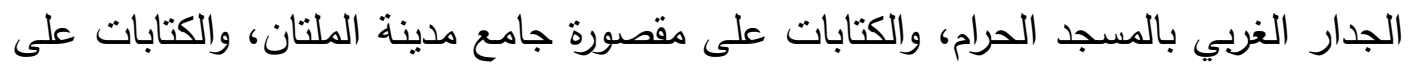
مقصورة جامع ذيبة المهل. وما بين نصوص جنائزية منل الكتابات على شاهدي قبر السيدة فاطمة بنت الحسين بمدينة الخليل. كذللك على قبر عون ابن سيدنا على رضي الله عنه. كذلك أيضاً على قبر سيدنا هو بالأحقاف. كذلك على قبر الإمام البخاري بمدينة بخارى.

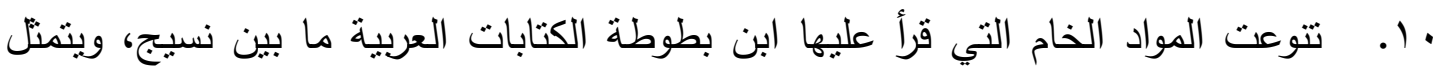

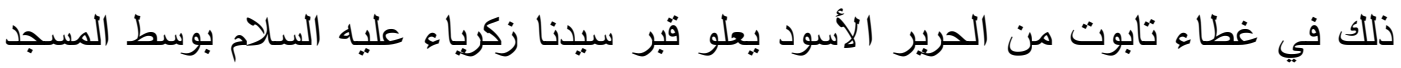

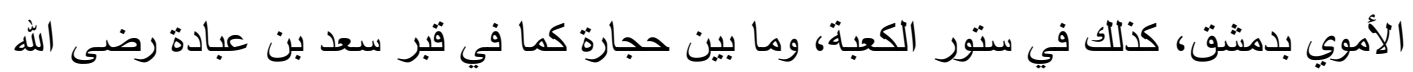

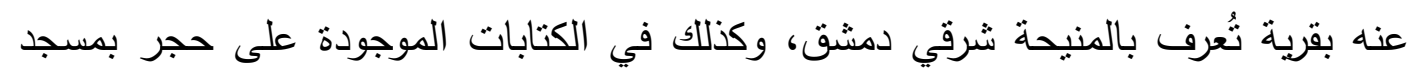
الأقدام بذمشق، وما بين رخام كما في شاهدي قبر فاطمة بنت الحسين بن علي عليهما

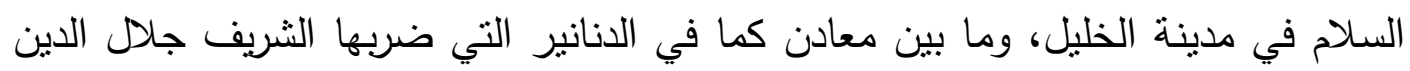

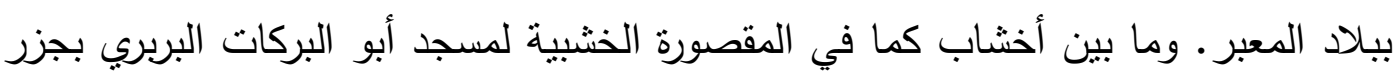

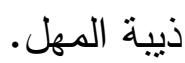


11. تتوعت الأماكن التي قرأ عليها ابن بطوطة النقوش العربية ما بين القبور وشواهدها،

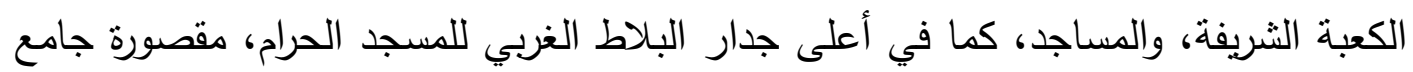
دهلي، مقصورة جامع ذيبة المهل.

r ا. كثف لنا ابن بطوطة عن مصطلح جديد لثاهد القبر وهو لفظ (قبرية) في المغرب.

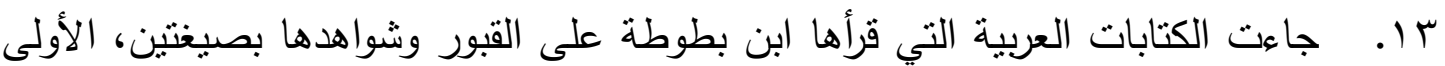

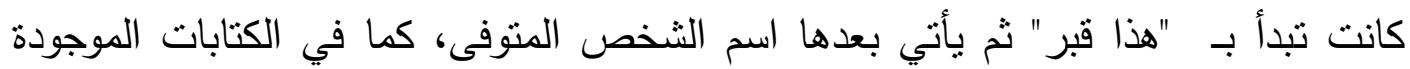
على شاهدي قبر السيدة فاطمة بنت الحسين بمدينة الخليل، كذللك في الكتابات الموجودة على حجر بعلو رأس قبر سيدنا سعد بن عبادة بالمنيحة شرقي دمثق، أيضاً في الكنابات الموجودة على قبر عون بن سيدنا على بمدينة بغداد ، كذلك في الكتابات الموجودة على قبر بلى بلى لئري

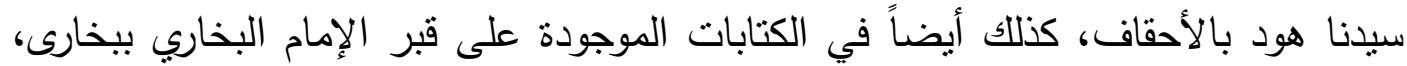
والصيغة الثانية كان بعض الصالحين برى المصطفى صلى الله عليه وسلم في النوم فيقول له: هاهنا قبر ثم يأتي بعدها اسم الثخص المقبور • ووردت مرة واحدة فقط على حجر موجود بمسجد الأقدام بمدينة دمشق.

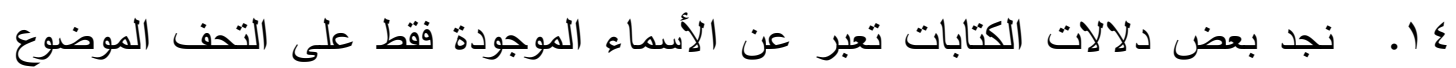
عليها الكتابات مثل اسم سيدنا زكرياء الموجود على غطاء قبره الموجود في وسط المسجد

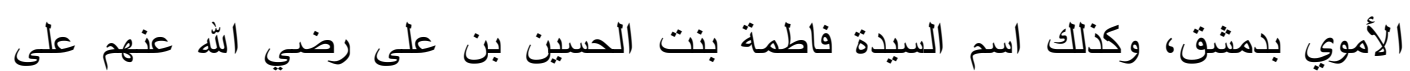

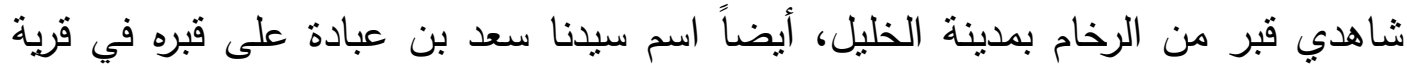
المنيحة، واسم سيدنا موسى على حجر موجود بمسجد الأقدام بمدينة دمشق، واسم الكعبة على كسوة الكعبة، واسم عون بن سيدنا على بن ابي طالب على قبره ببغداد، واسم سيدنا هود

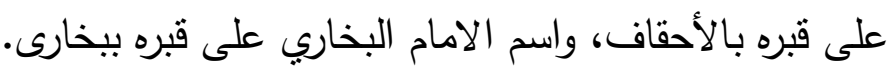




\section{هوامش البحث:}

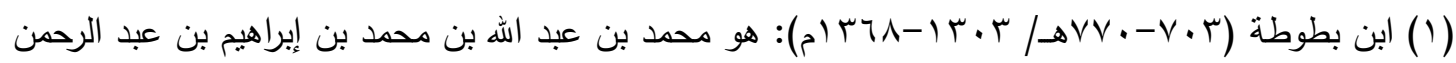

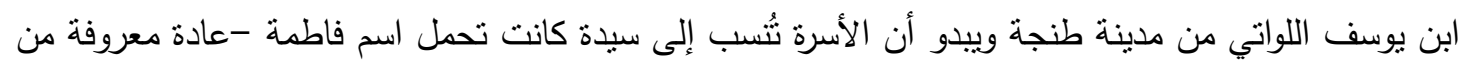

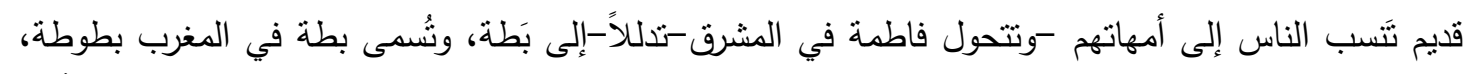
وقد لُقب في المشرق بشمس الدين، وفي الهند بمولانا بدر الدين، وكانت أسرته عريقة المجد عالية المقام أثنيح

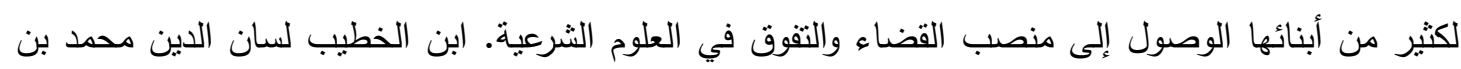

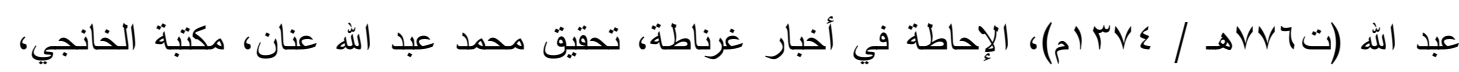

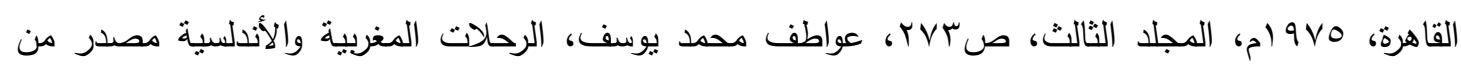

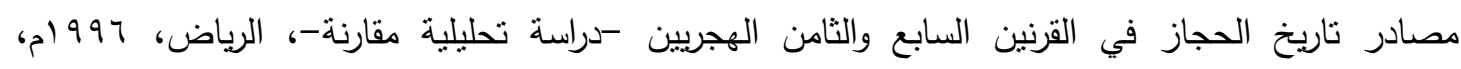

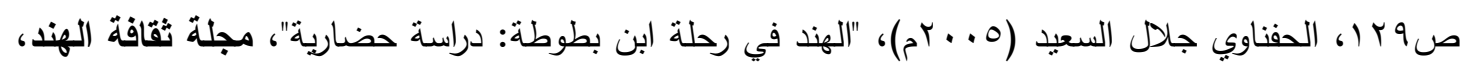

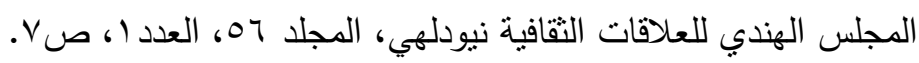

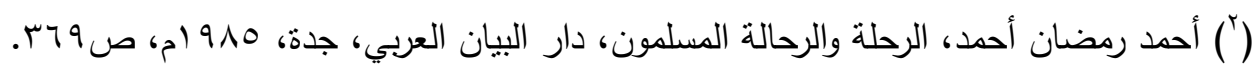

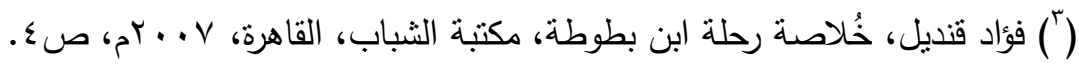

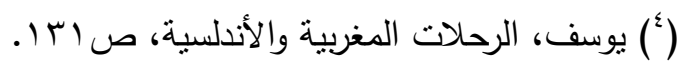

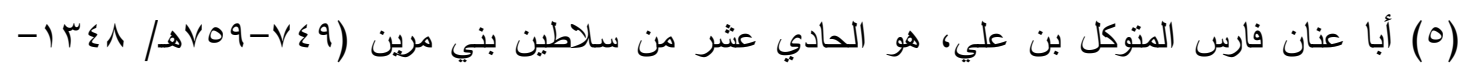

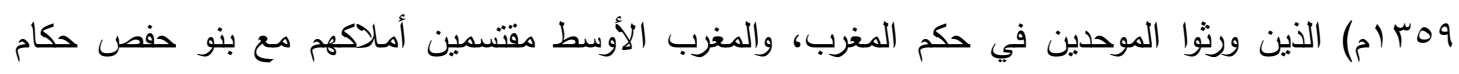

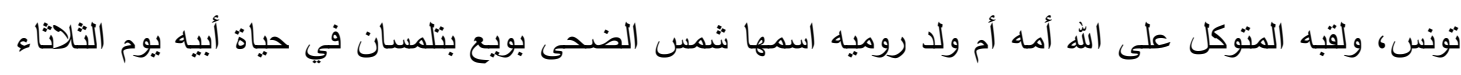

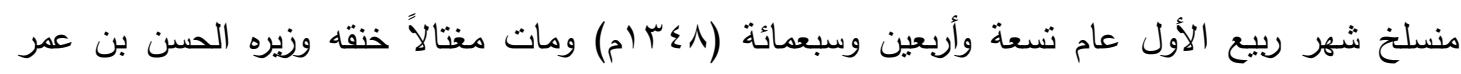

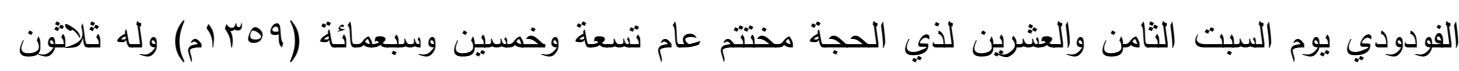

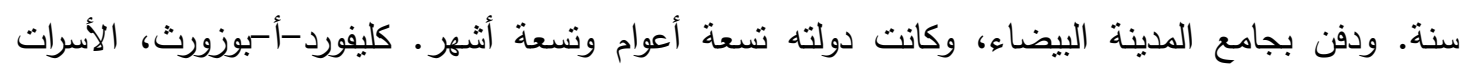

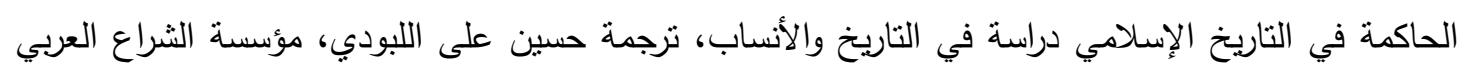

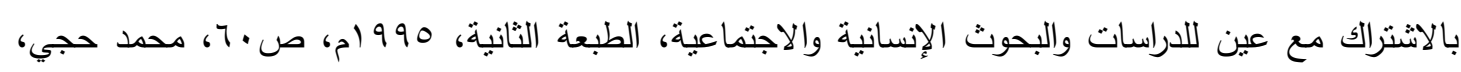

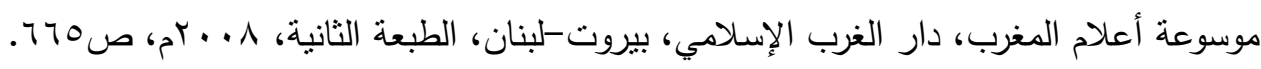

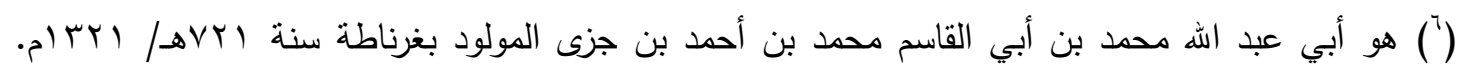

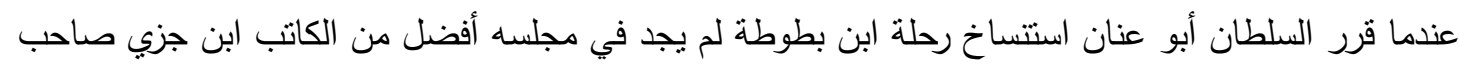

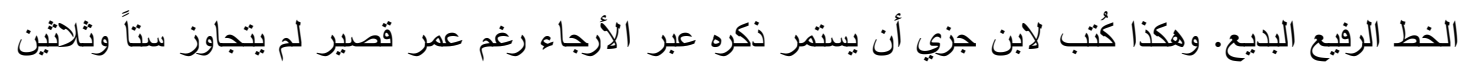

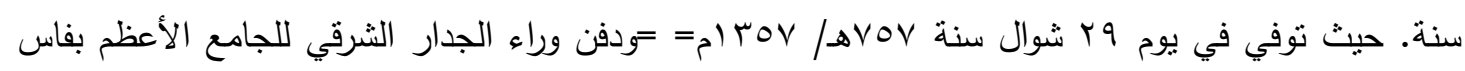

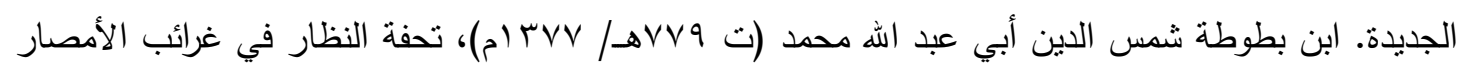

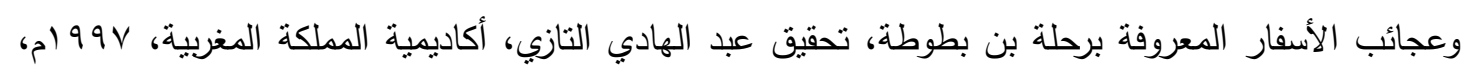

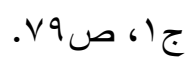

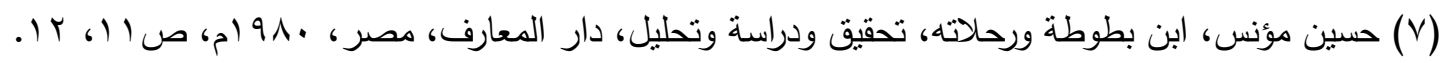

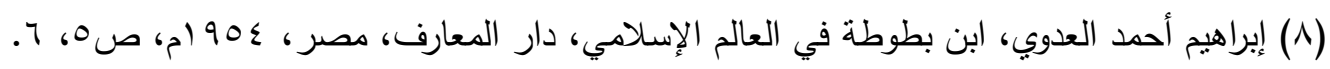


(9) أغناطيوس يوليا نوفتش كراتكوفسكي، تاريخ الأدب الجغرافي العربي، نرجمة صلاح الدين عثمان هاشم،

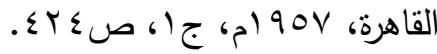

( • (1) حسان حلاق: مكة المكرمة من خلال رحلتي ابن جبير وابن بطوطة، دار النهضة العربية، بيروت-لبنان،

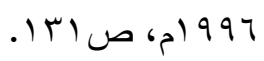

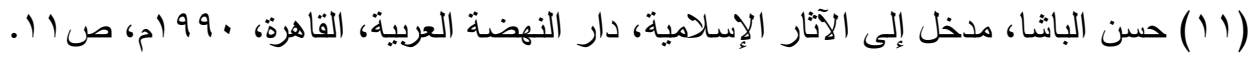

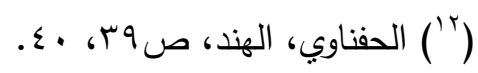

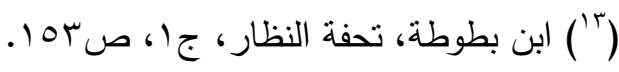

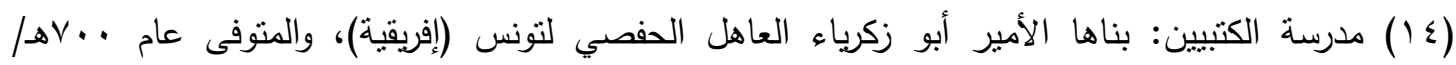

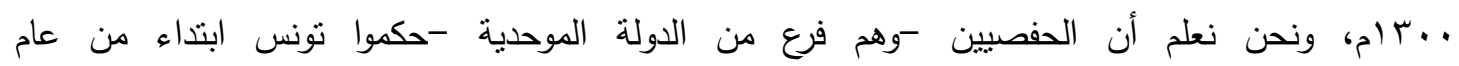

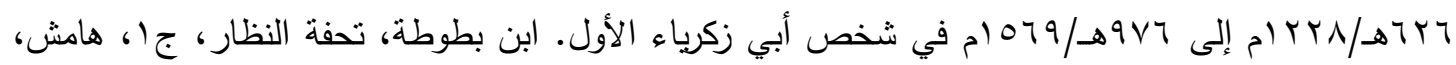

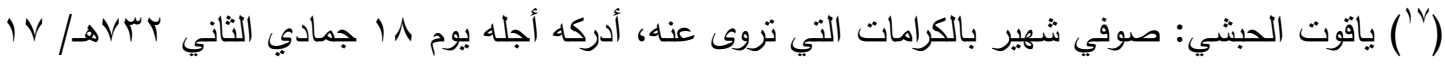

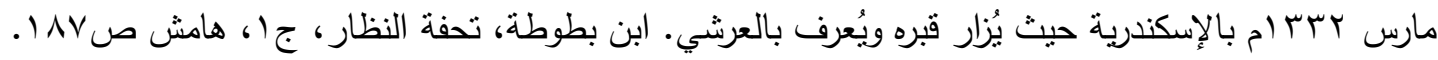

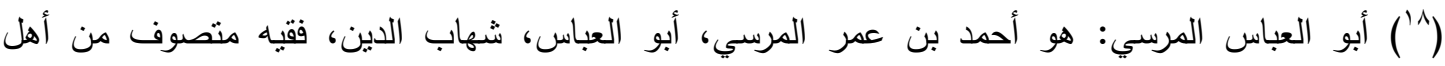

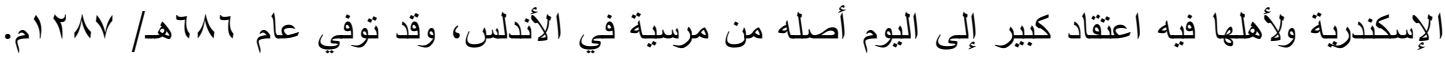

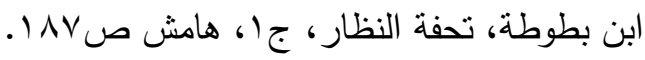
(9 (19) أبو الحسن الثناذلي: هو على بن عبد الله بن عبد الجبار، وينتهي نسبه إلى الحسن بن علي، وقد ولد في

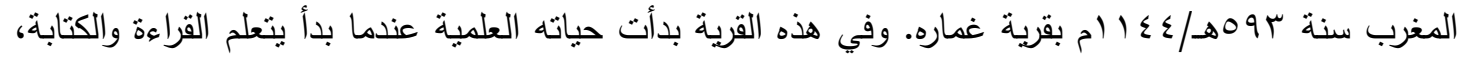
ثم حفظ القرأن الكريم، وبدأ يتفقه في أمور الدين، ثم جرفه الحنين إلى عالم الصوفية بما فيه من أنوار، وهوه مؤسس الطريقة الثاذلية، ولد في قبيلة شاذلة فُسب إليها، ورحل إلى بلاد المشرق، ودخل فرله العراق ثم سكن

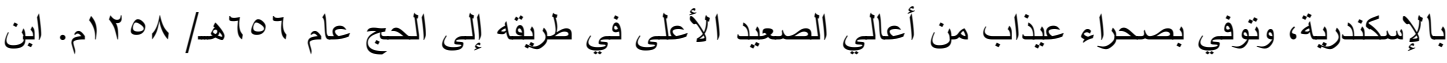

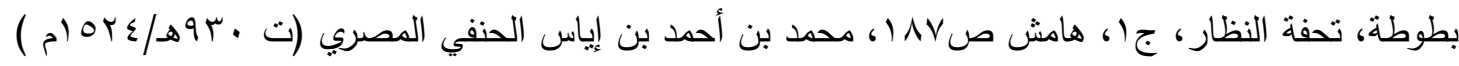

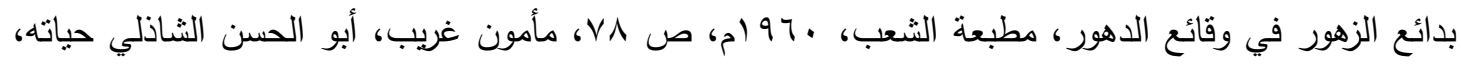

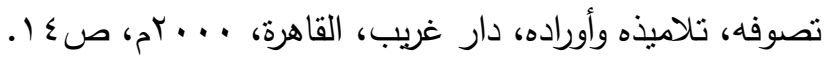

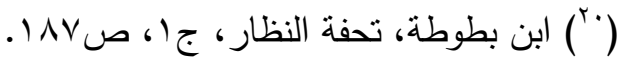

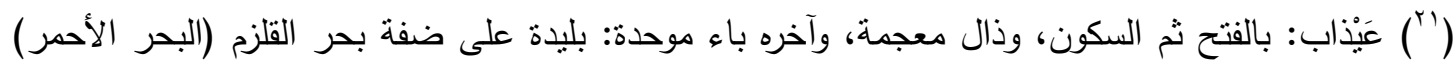

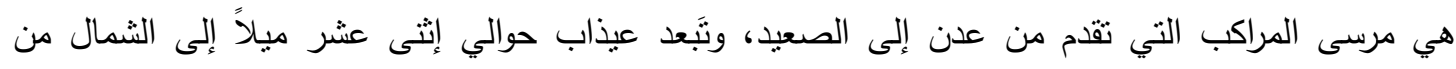

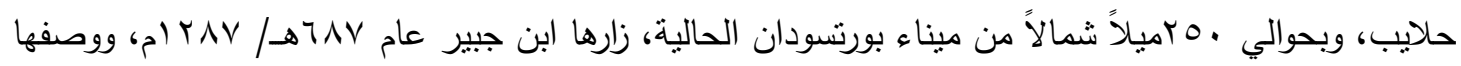

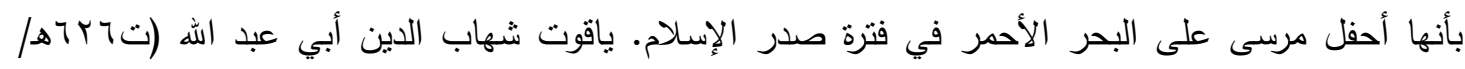

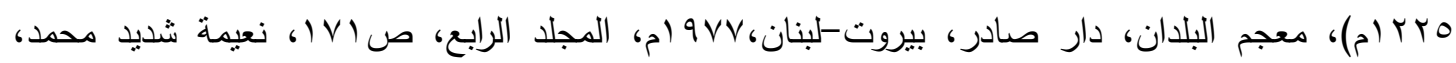


"أهية الموانئ السودانية للتجارة الدولية عبر البحر الأحمر خلد العصر الإسلامي"، مجلة جامعة الملك عبد

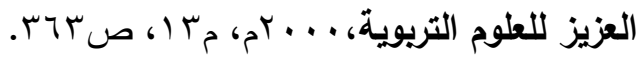

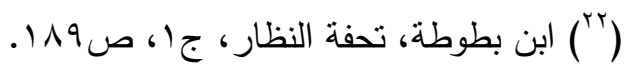

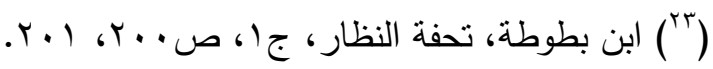
( ) بُعدّ البيمارستان المنصوري علامة حضارية مميزة لعصر سلاطين المماليك بعامة، ولعهد السلطان قلاوون

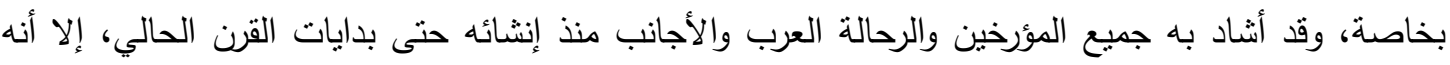

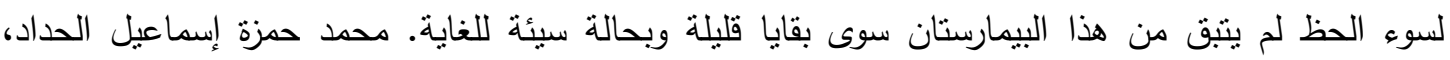

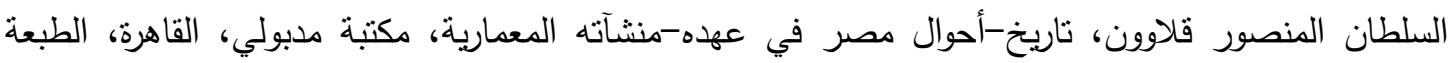

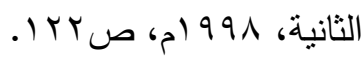

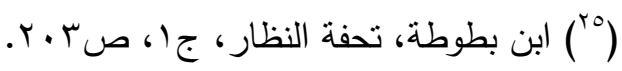

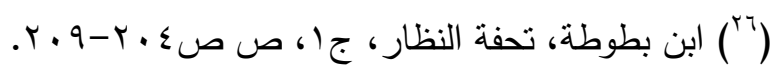

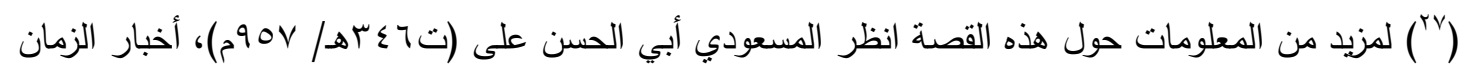

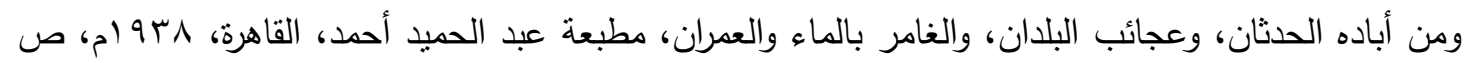
ص 1.1.-11.

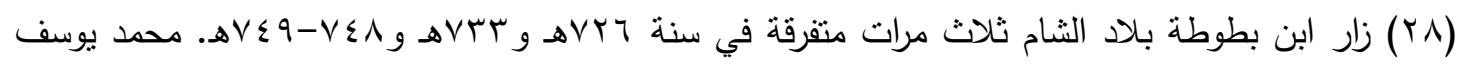

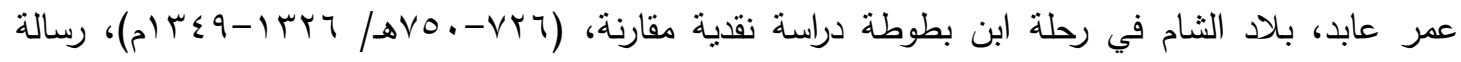

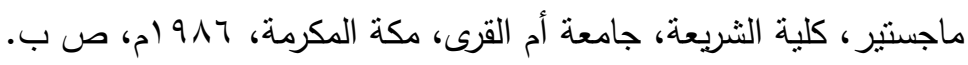

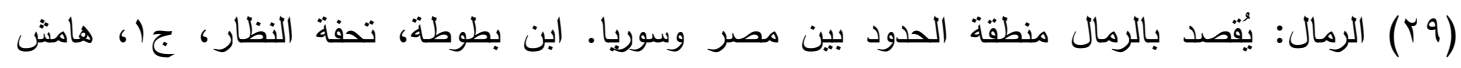

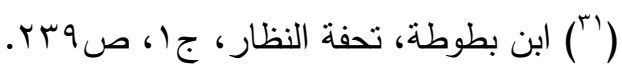
(rr ) مسجد اليقين: يُنكر أنه لما رأى إبراهيم عليه السلام قريات لوط في الهواء، رقد، ثم قال: أشهرد أن هذا لهو

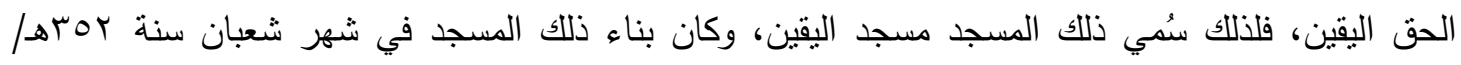

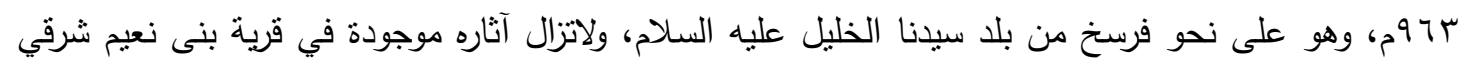

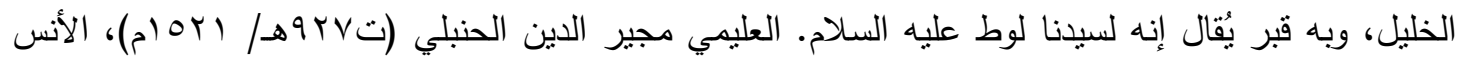

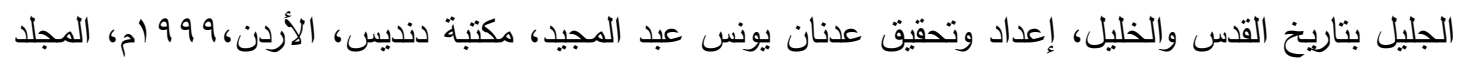

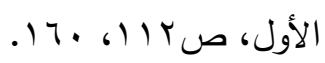

(TrT) فاطمة ابنة الحسين بن علي عليهم السلام، أمها أم إسحاق التميمية بنت طلحة بن عبيد الله، وتزوجها ابن

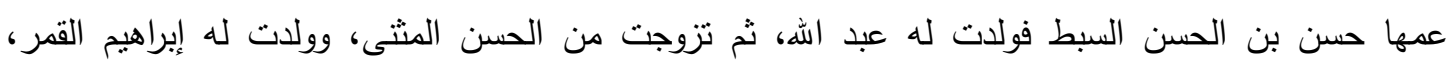

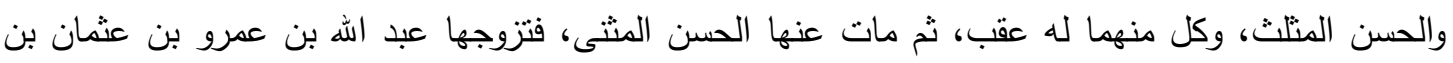

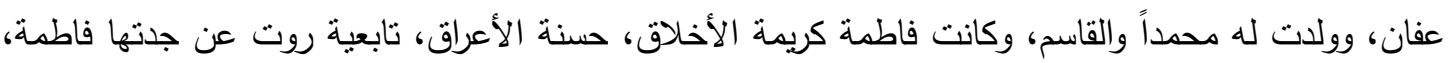

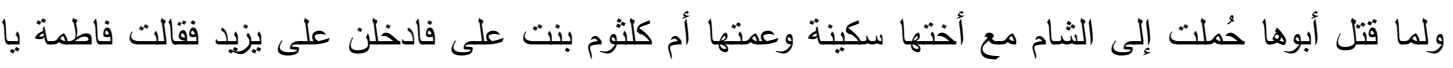




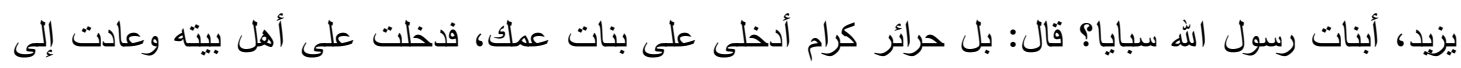

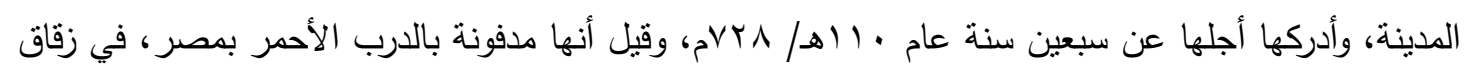
يُعرف بزقاق فاطمة النبوية في مسجد جليل، ومقامها عظيم وعليه المهابة والجلال. وما اثتهر من أن فاطمة

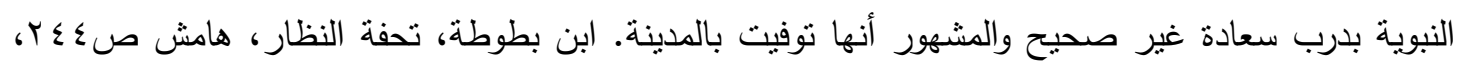

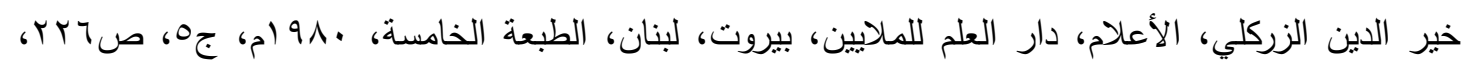

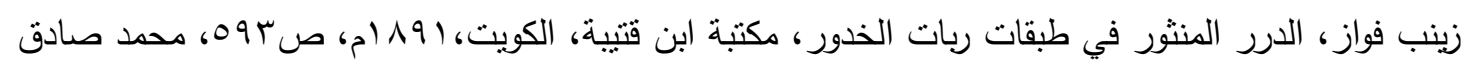

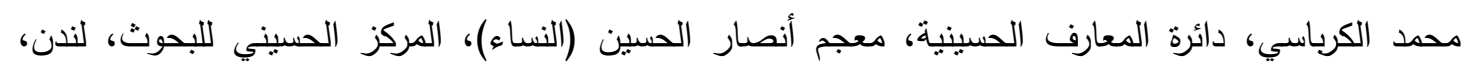

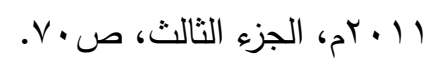

(ع (أوردها الكرباسي وفي رسول الله أسوة وعزاء. الكرباسي، دائرة المعارف الحسينية، الجزء الثالث، ص. • V.

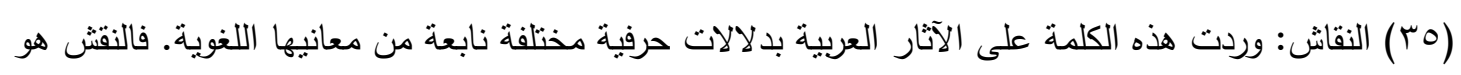

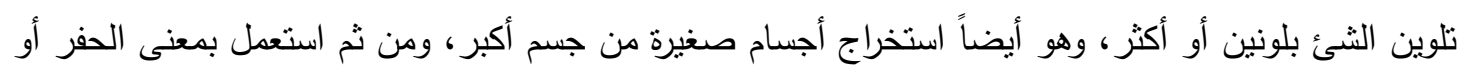

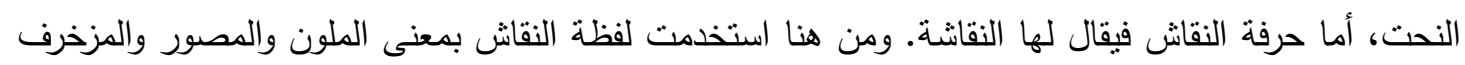

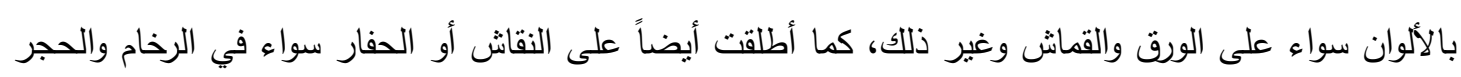
والجص والخشب والمعدن والفخار وغير ذلك من المواد. وقد ورد بهذه الدلالة على كثير من الآثار العربية.

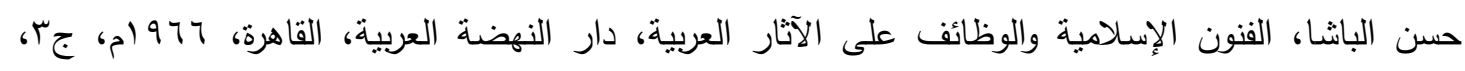

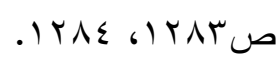
(ד؟T) ذكر العليمي: وبظاهر المسجد (مسجد اليقين) مغارة بها قبر فاطمة بنت الحسن بن علي بن أبي طالب،

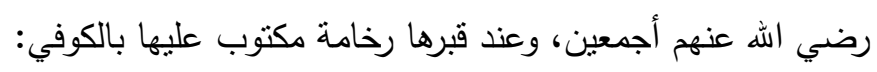

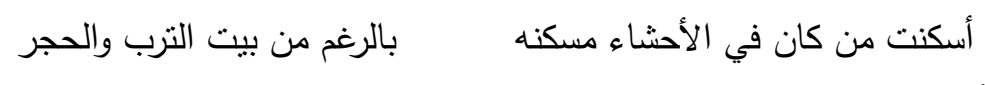

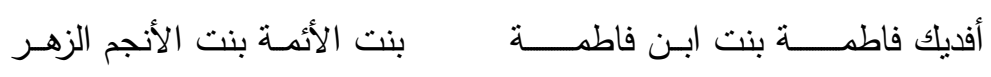

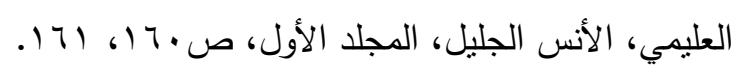

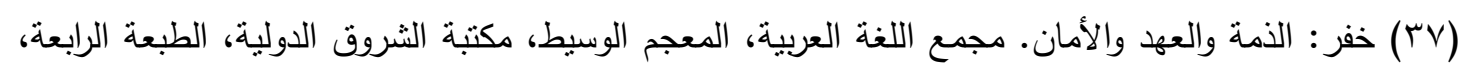
.r

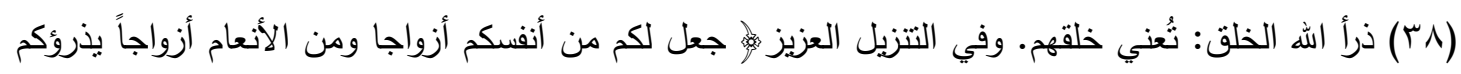

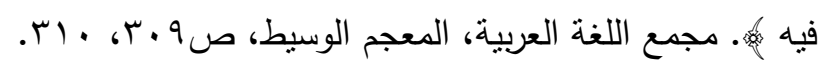
(1) برأ الله الخلق: تُعني خلقهم أيضاً، فمن أسماءه الحسنى البارئ أي الخالق. مجمع اللغة العربية، المعجم

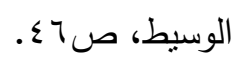

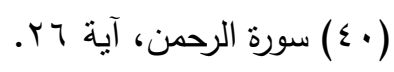

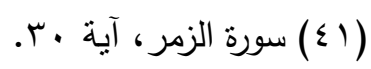

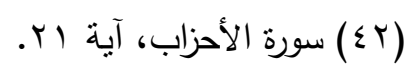

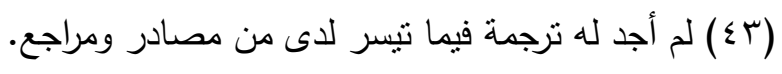

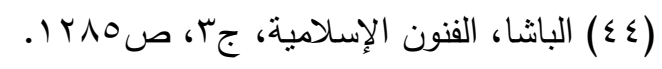




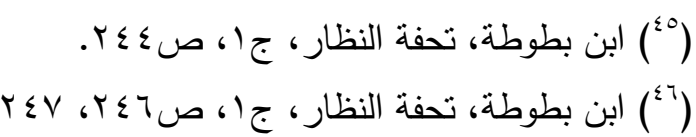

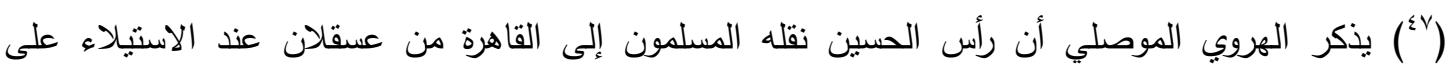

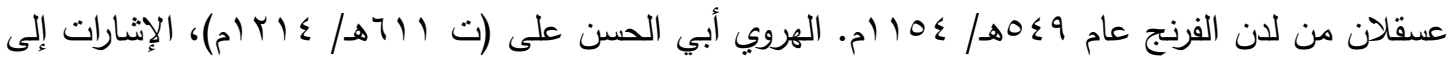

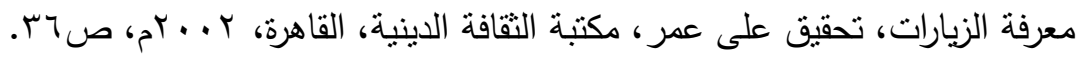
(A乏) القصد إلى الخليفة الفاطمي المستتصر (

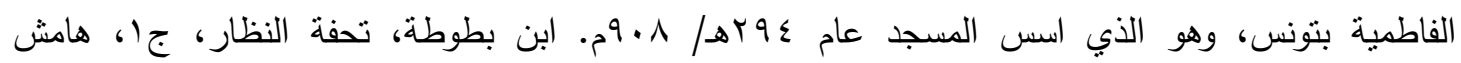
ص ror

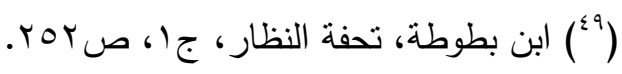
(") كانت هذه المدرسة توجد بدرب الثعارين، لصيق حمام صالح، شمالي الطيوريين، داخل باب الجابية

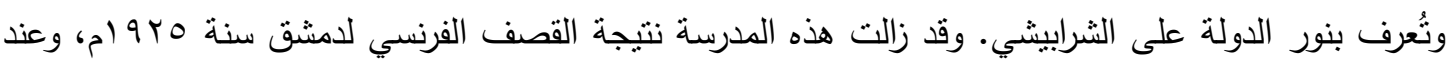
ذكر ابن بطوطة لمدارس دمشق ذكر: أن للمالكية بها ثلاث مدارس ذكر منهم المدرسة الثرابشية، وذئة وذكر : أنه

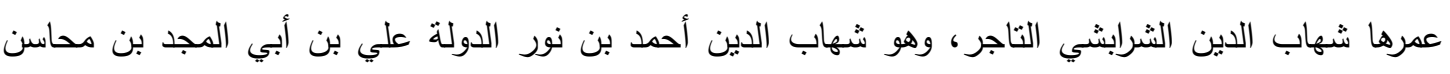

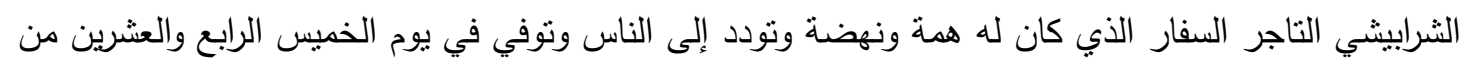

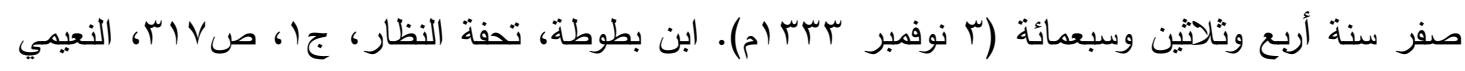

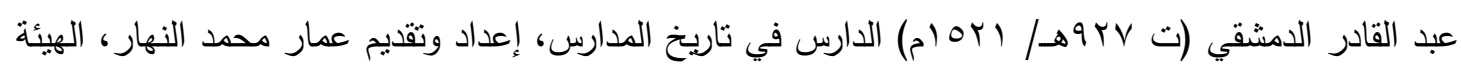

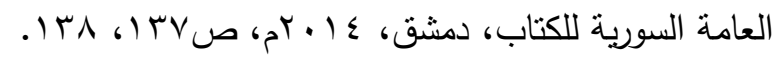

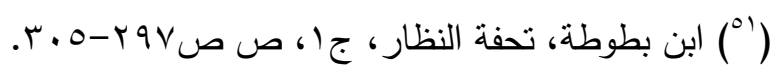

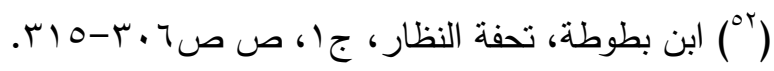

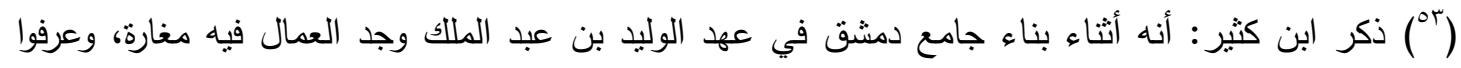
الوليد بذللك، فلما كان الليل وافاهم وبين يديه الثمع، فنزل فإذا هي كنيسة لطيفة، ثلاثنة أذرع في ثلاثة أذرع، وإذاذ

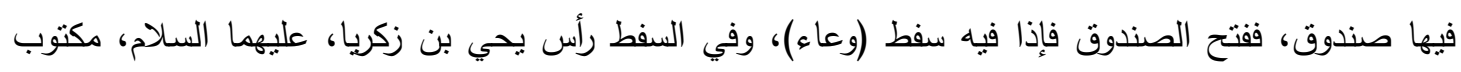

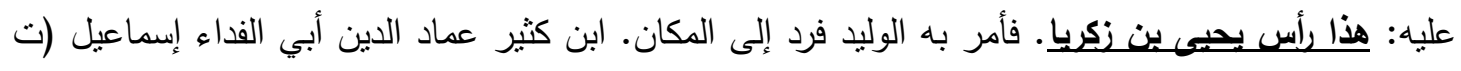

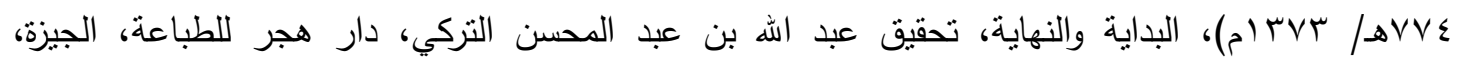
( 99191

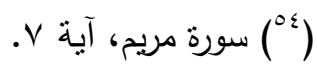

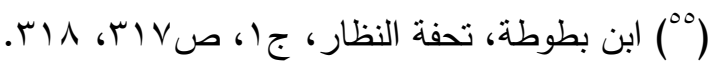

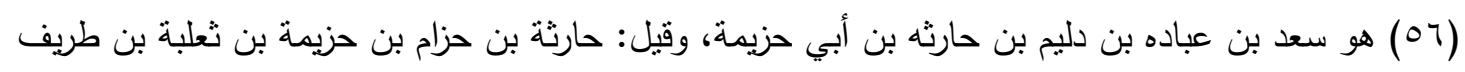

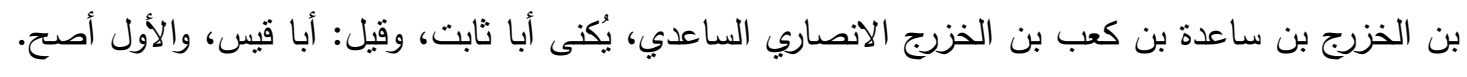
سيد الخزرج وأحد الأمراء الأثراف في الجاهلية والإسلام، وشهد العقبة مع السبعين من الأنصار في روايتهم

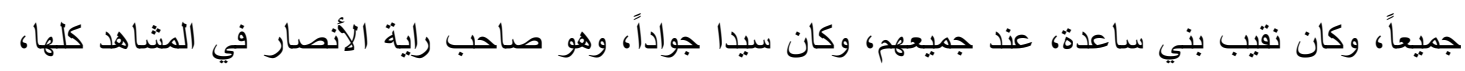

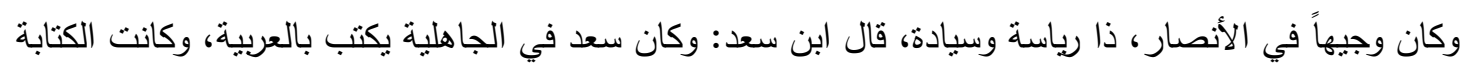


في العرب قليلاً، وكان يُحسن العوم والرمي، خرج إلى الثام مهاجراً من أول خلافة عمر رضي اله عنه، فمات

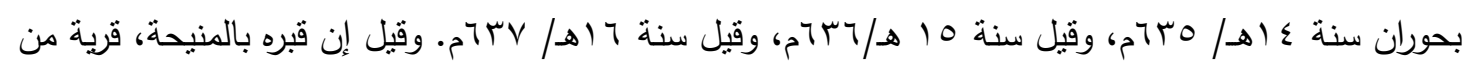

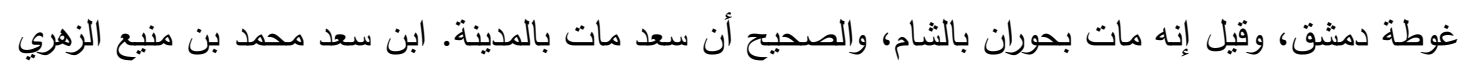

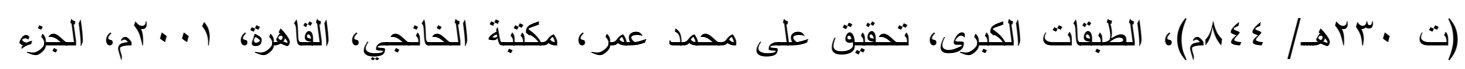

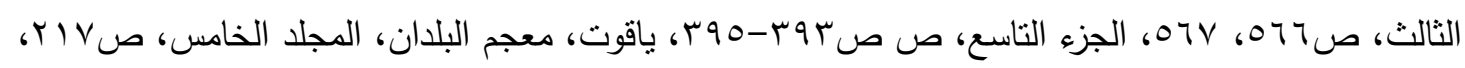

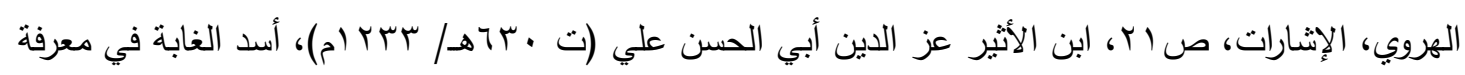
الصحابة، تحقيق وتعليق على محمد معوض، عادل أحمد عبد الموجود، دار الكتب العلمية، بيروت-

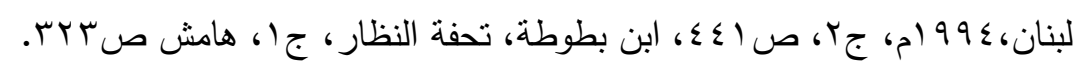

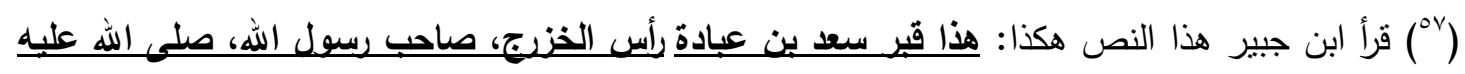
وسلم.نجد اختلاف بسيط بين نص ابن بطوطة وابن جبير في أن نص ابن بطوطة ينتهي بكلمة تسليماً. ابن

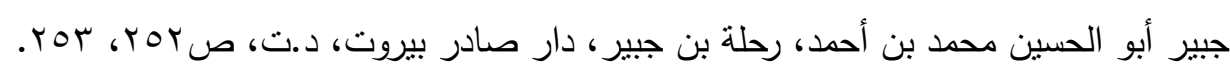

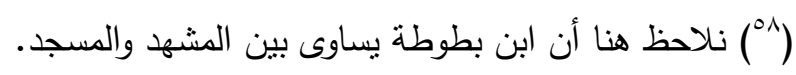

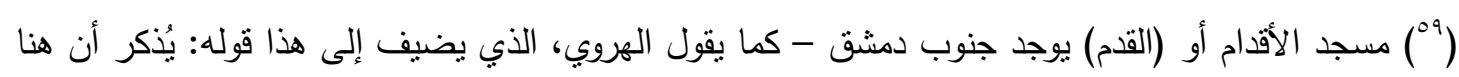

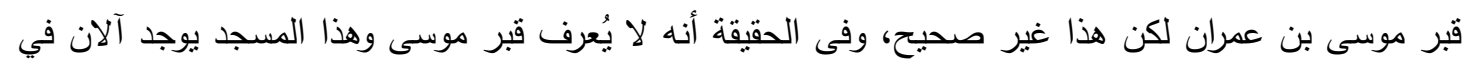

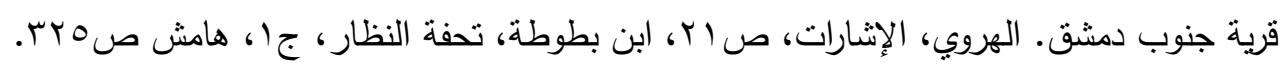

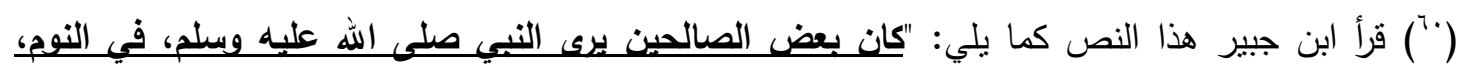

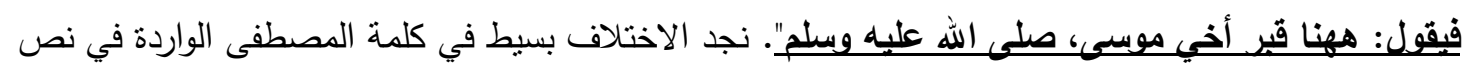

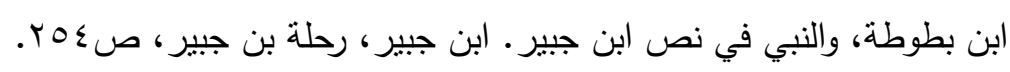

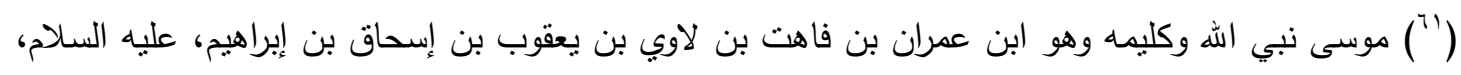

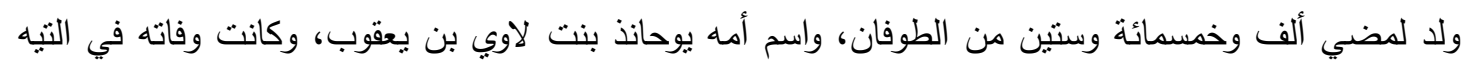

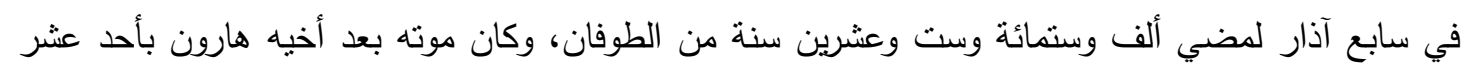

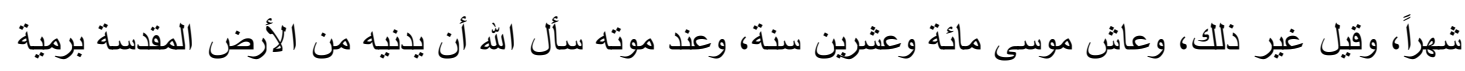
حجر، قال رسول الله صلى الله عليه وسلم، 》فلو كنت ثم لأريتكم قبره إلى جانب الطريق عند الكثيب الأحمرهان. واختلف الناس في محل قبره، فقيل وهو المشهور عند الناس: إنه شرقي بيت المقد. العليمي، الأنس الجليل،

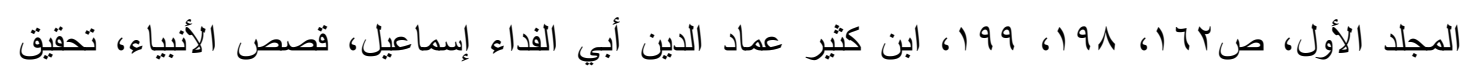

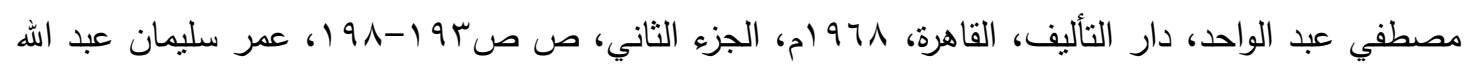

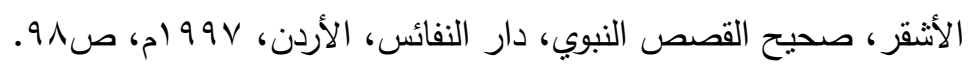

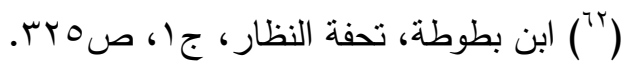
("T) لأبن بطوطة أربع رحلات إلى مكة، وسبع حجات، وصام فيها ثلاثة رمضانات، وهذا مالم يتيسر لغيره،

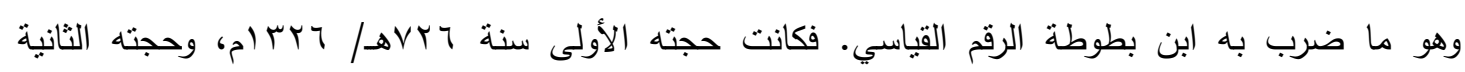
 


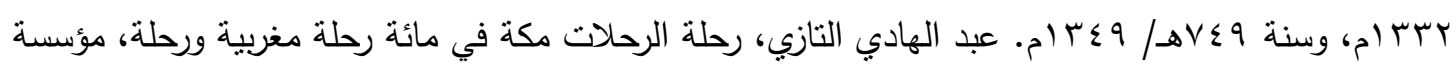

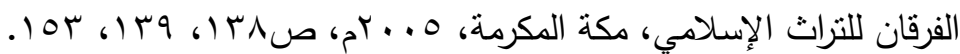

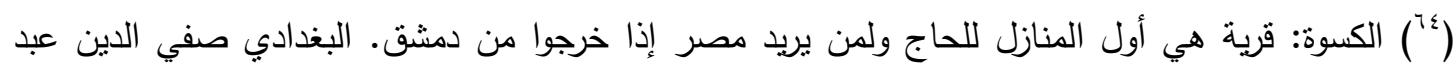

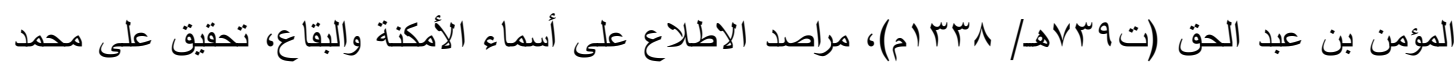

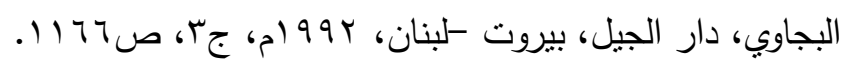

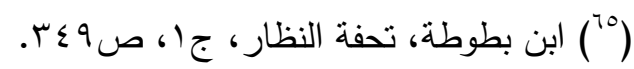

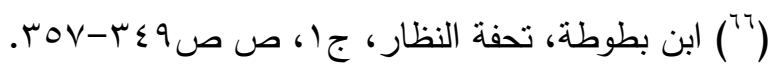
( ) المهدي: وهو اللقب الذي اتخذه محمد بن عبد اله المنصور العباسي، الهاشمي، القرشي، أبو عبد اله:

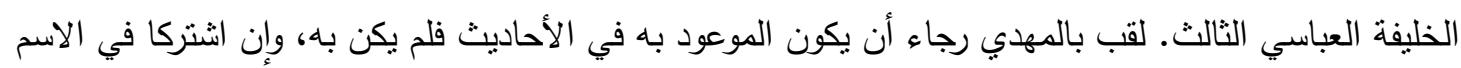

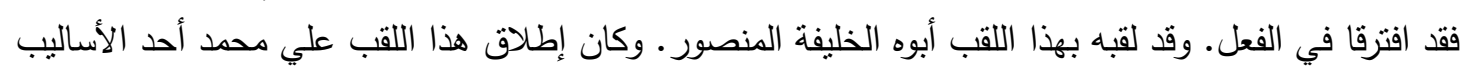

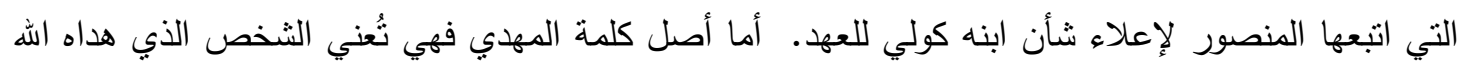

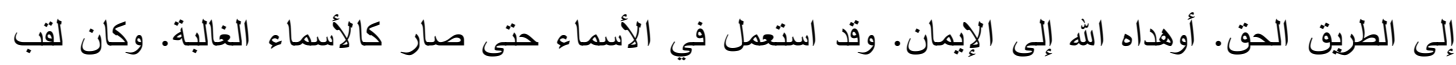

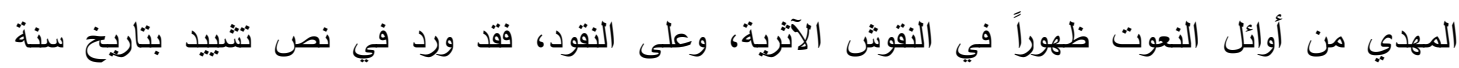

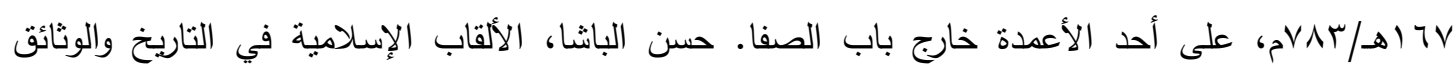

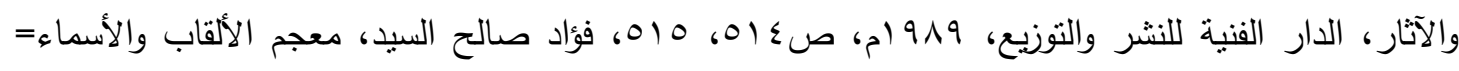

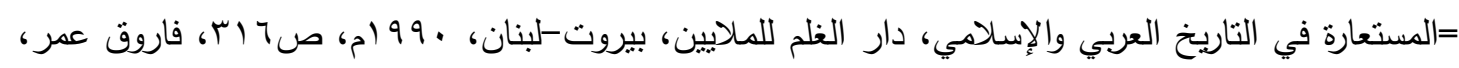

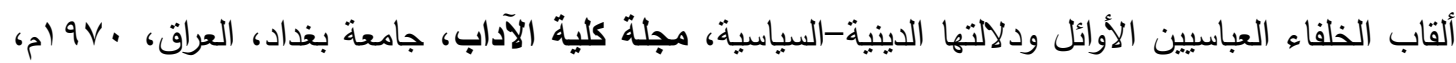

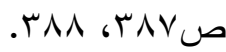

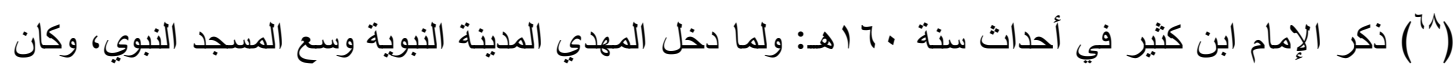

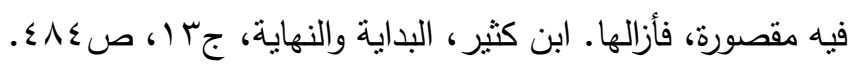

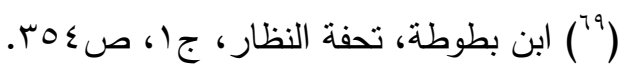

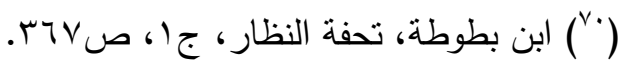

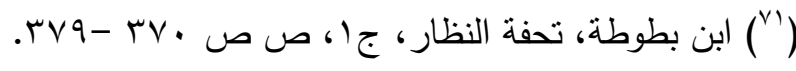

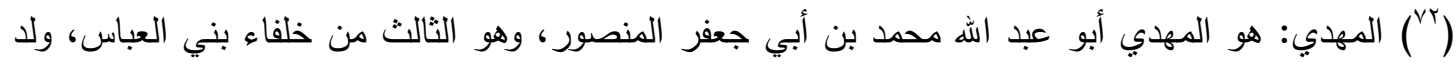

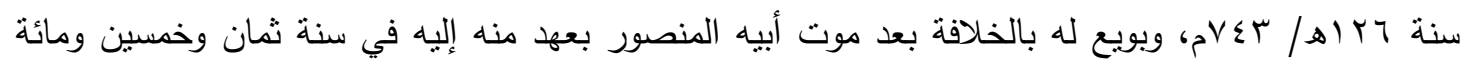

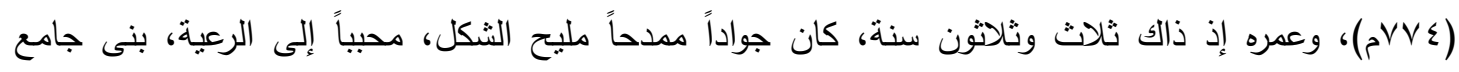
الرصافة، وأمر ببناء القصور في طريق مكة، وكسا الكعبة القباطي، والخزف والديباج، وطلى جدرانها بالمسك إنك

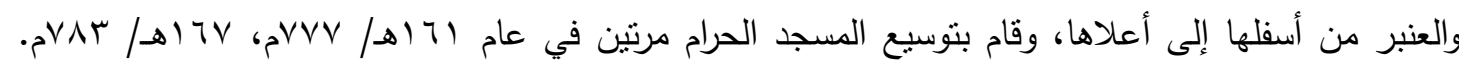

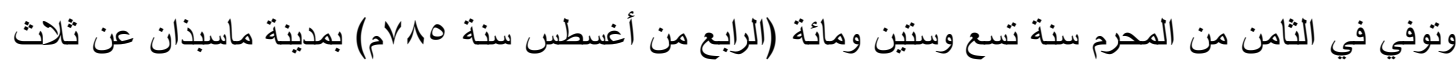

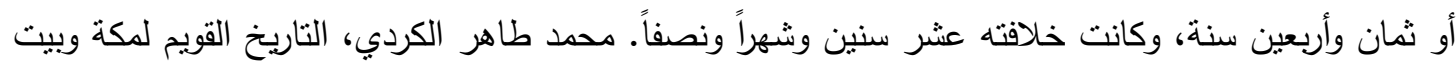

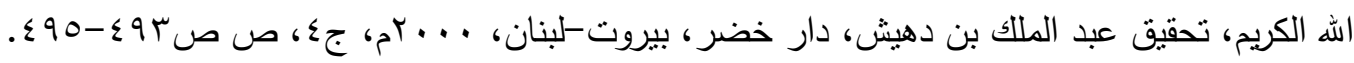


عبد الله: لقب عام للخلفاء، إذ يُكتب في نعت الخليفة في المكاتبات ونحوها، وأول من تلقب به أمير

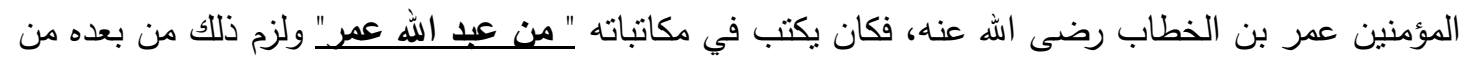

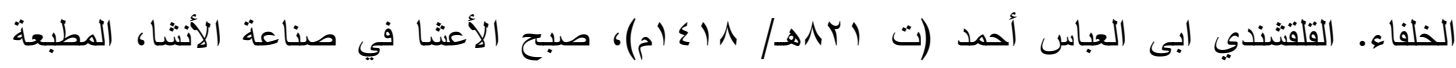

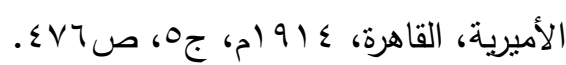

( أمير المؤمنين: وهو لقب عام للخلفاء. وأول من لقب به منهم عمر بن الخطاب رضي الله عنه في أثناء

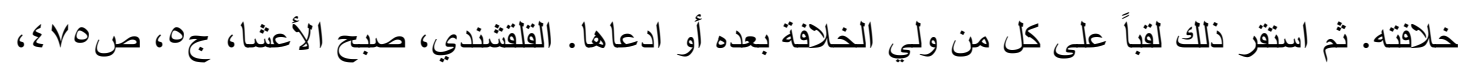

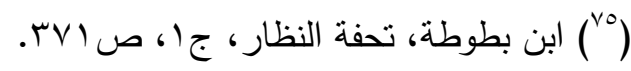

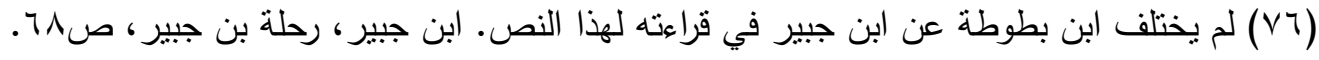

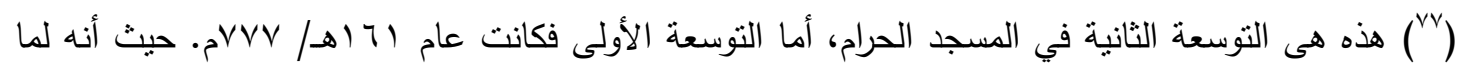

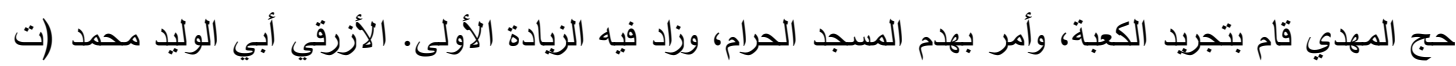
•

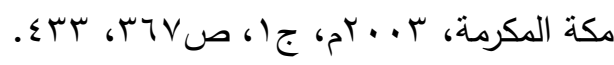
( ) هو محمد بن عبد الرحمن بن هثام بن بحي بن هثام بن العاص ابن هثام بن المغيرة، كان على قضاء

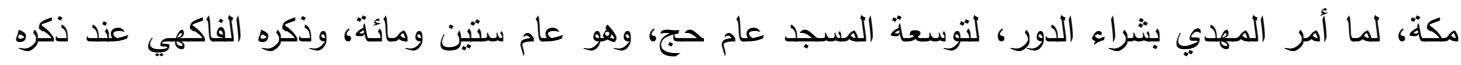

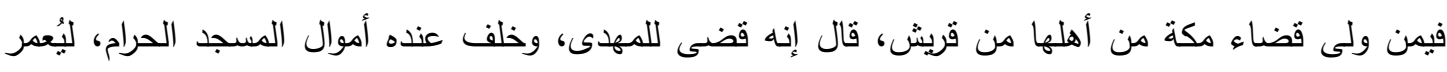

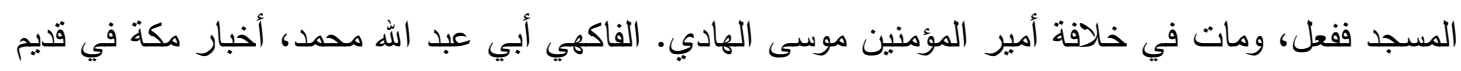
الدهر وحديثه، تحقيق عبد الملك بن عبد الله بن دهيث، مكتبة النهضة الحديثة، مكة، الطبعة الثانية، ع 99 ام،

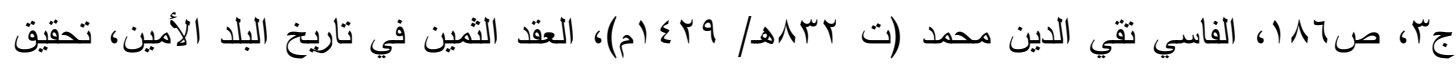

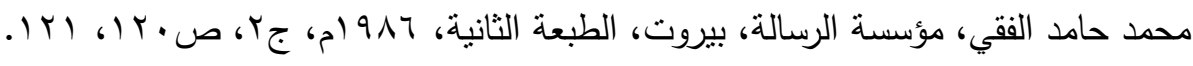

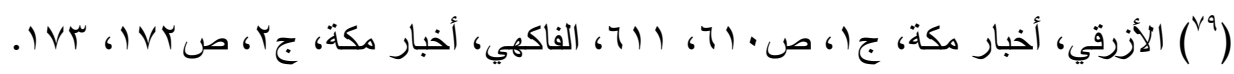

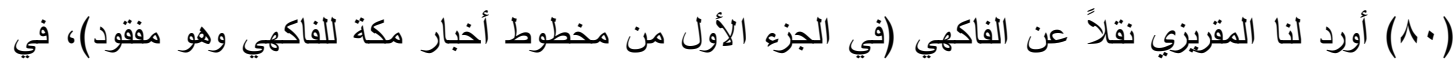

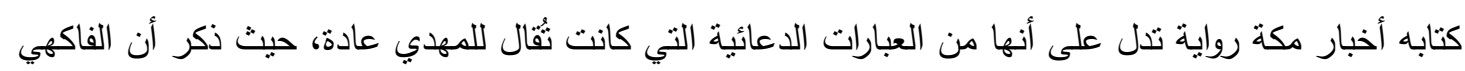

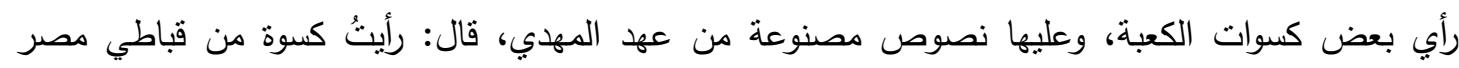
مكتوباً عليها: بسم الله، بركة من الله، مما آمر به عبد الله= =المهري محمد أمير المؤمنين-أصلحه اللها

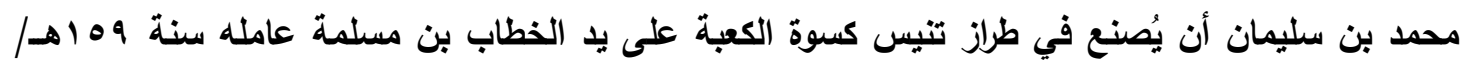

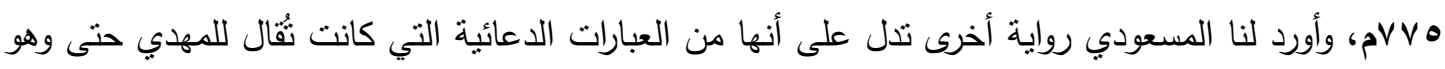

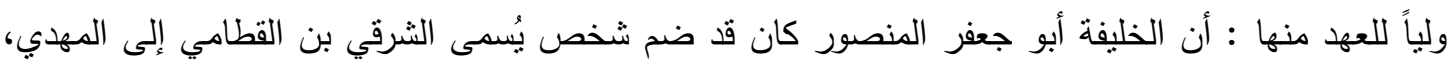

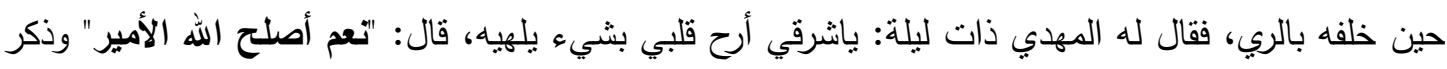

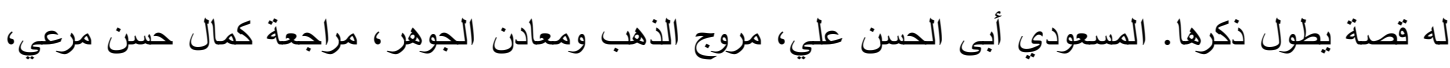

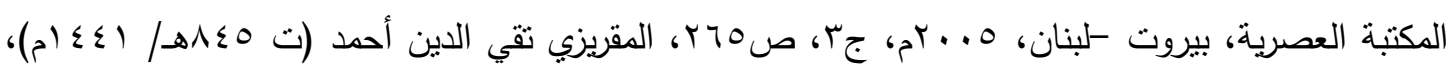
الذهب المسبوك في ذكر من حج من الخلفاء والملوك، تحقيق جمال الدين الثبال، مكتبة الثقافة الدينية، القاهرة، 


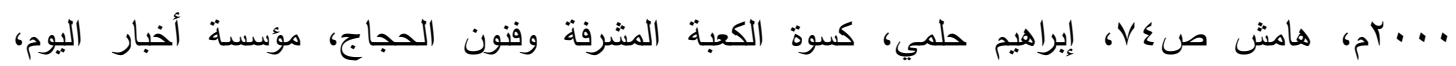

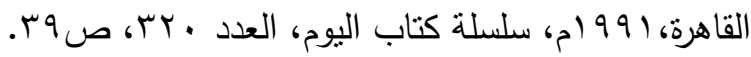

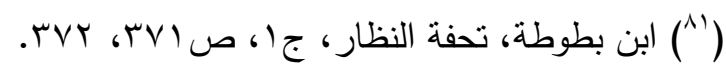

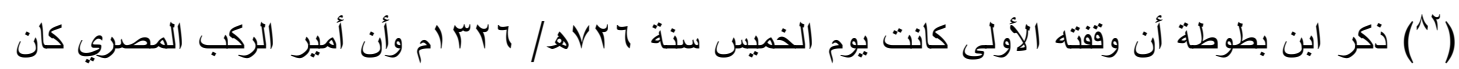

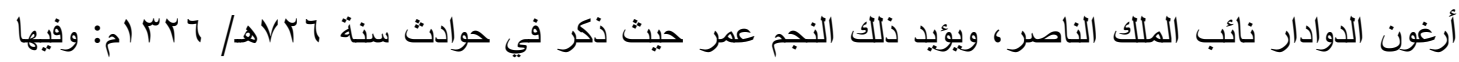
حج أرغون الدوادار نائب السلطنة بمصر، وولده ناصر الدين محمد، ويعتبر ابن بطوطة أول من انفرد بذكر فئر

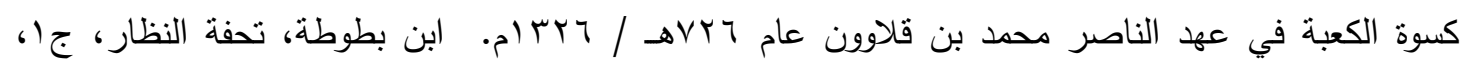

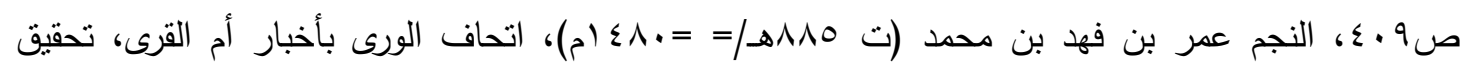

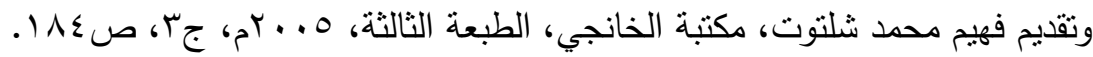

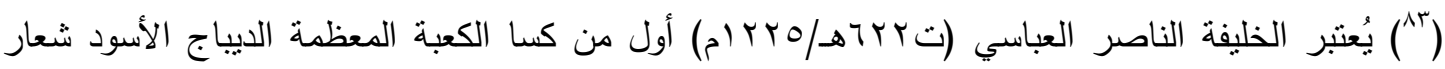
العباسيين في نهاية خلافته، وقد استمر من جاء بعده من الخلفاء والسلاطين في كسوتها بالديباج الأسود حتى دنى

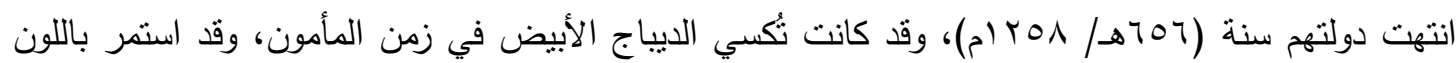

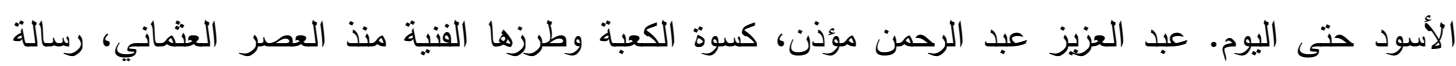

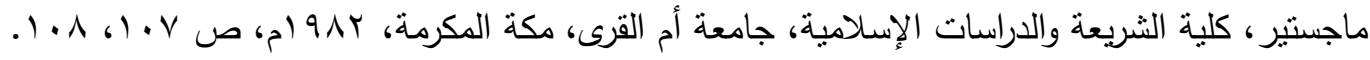

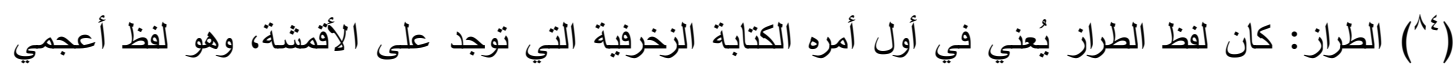

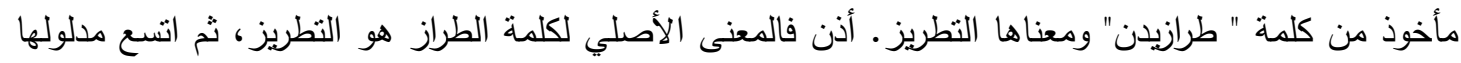

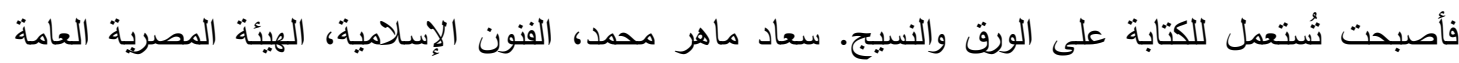

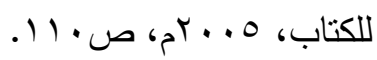

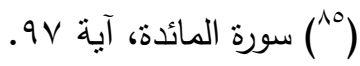

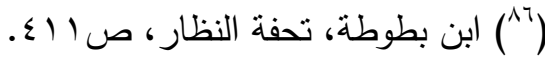

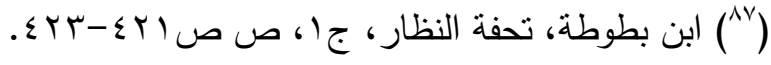

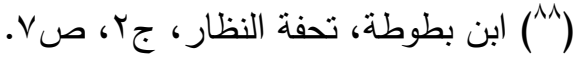

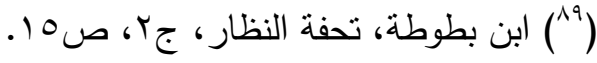

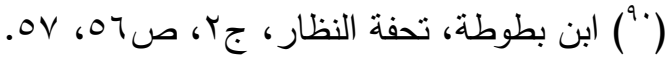

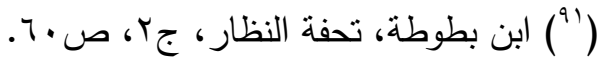

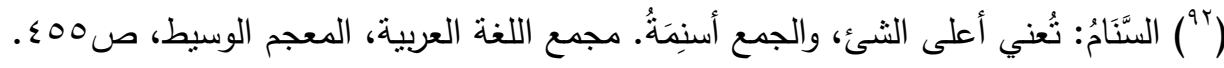

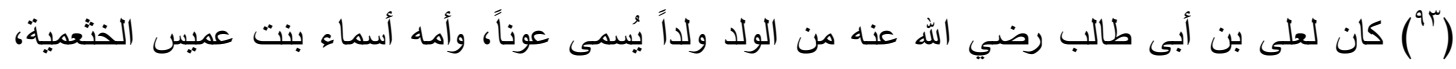
وكانت تحت أخيه جعفر، فلما استشهد في مؤتة تزوجها أبوبكر الصديق، وانجبت له له محمد بن أبي بكر ، فلما

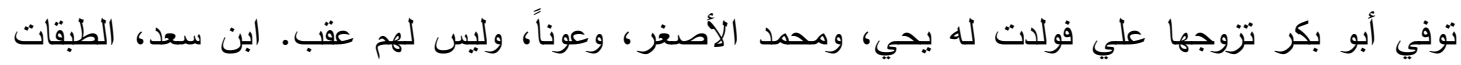

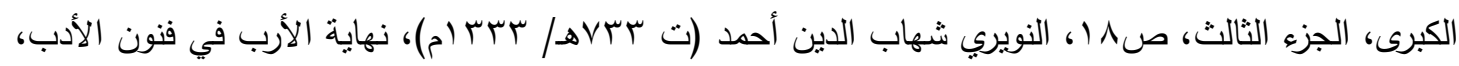

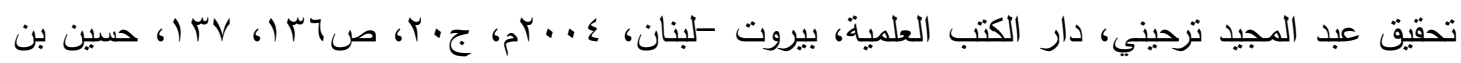


محمد ابن الحسن الديار بكري (ت747هـ/ 1009م)، تاريخ الخميس في أحوال أنفس نفيس، دار صادر،

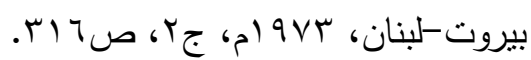
(צ') قرأ ابن جبير هذا النص هكذا: هذا قبر عون ومعبن، من أولاد أمبر المؤمنين علي بن أبي طالب رضي الله عنه". وهو يختلف عن نص ابن بطوطة فابن جبير زاد في نصه اسم معين، ولقب أمير المؤمنين وعبارة

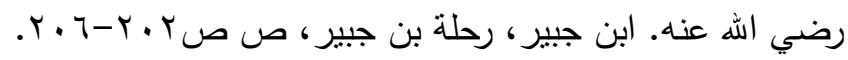

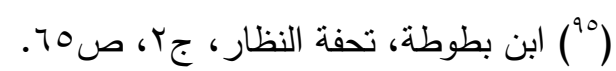

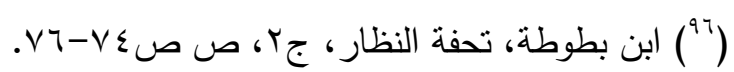

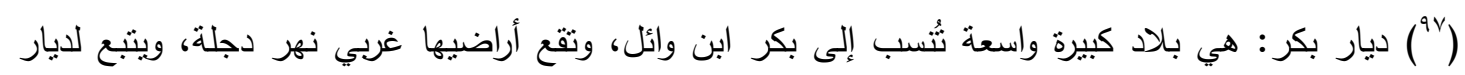

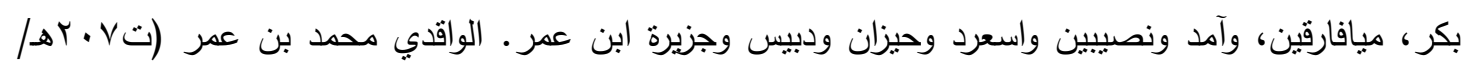

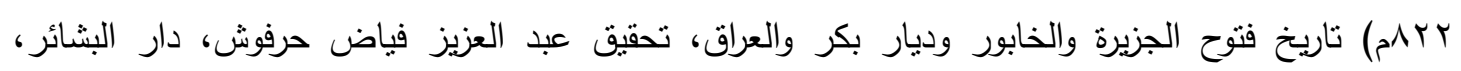

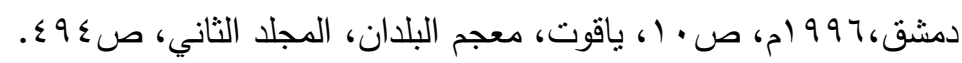

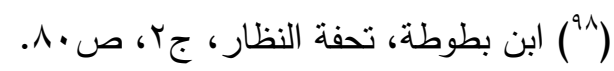

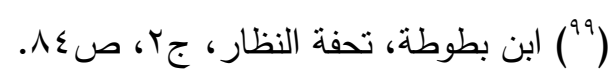

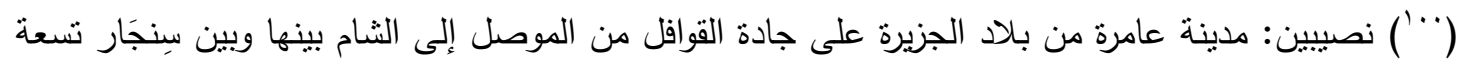

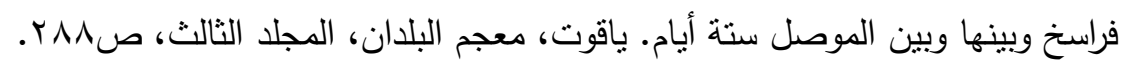

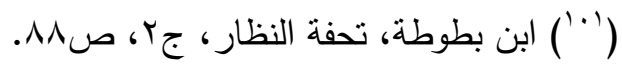

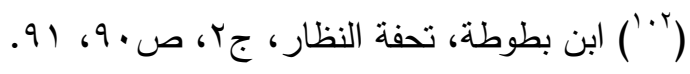

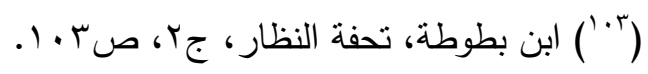

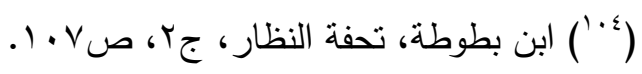

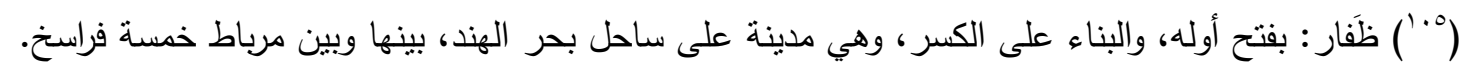

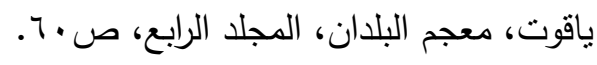

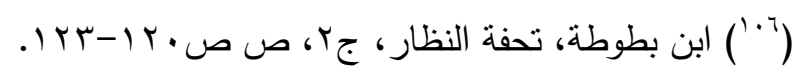
( (·v) الأحقاف: الأحقاف جمع حقف من الرمل، والعرب تسمي الرمل المعوج حقافا وأحقافاً، والأحقاف المذكور

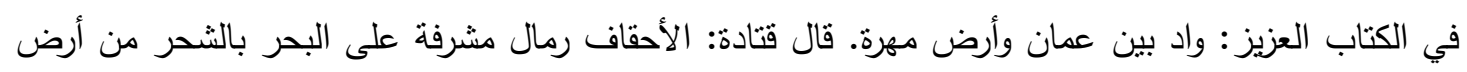

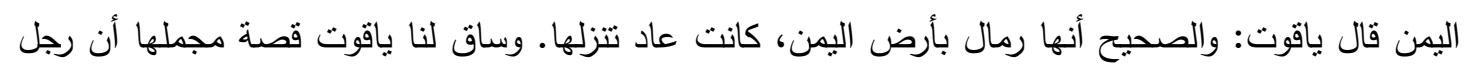

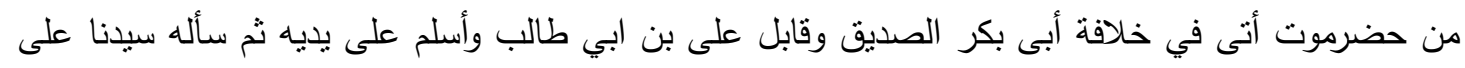

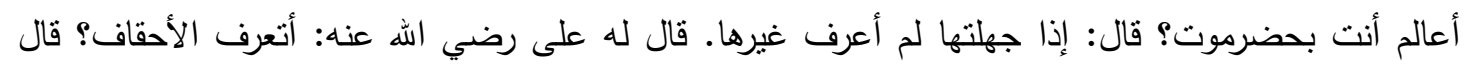

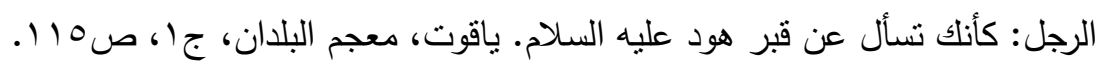

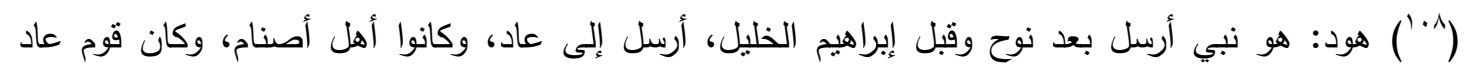

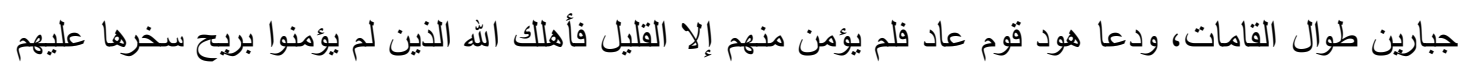

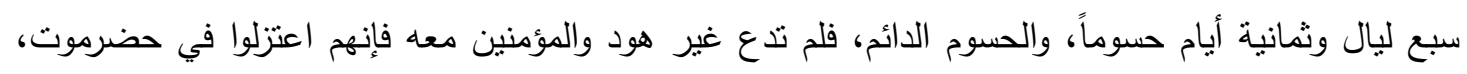


وبقي هود كذلك حتى مات وقبره بحضرموت، وقيل: بالحجر من مكة. العليمي، الأس الجليل، المجلا الأول، ص ص 94.

(9 • (1) ذكر ابن بطوطة: عند ذكره لفضائل مسجد دمشق أنه يُقال إن الجدار القبلي منه وضعه نبي الهه هود

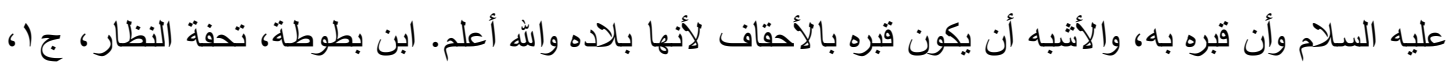

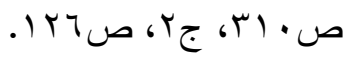

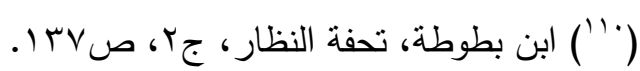

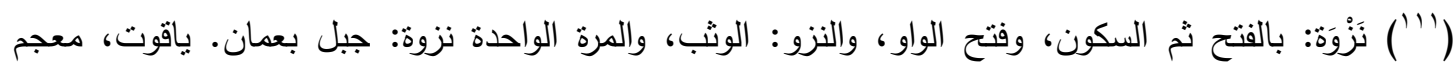

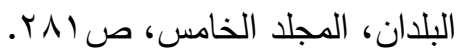
('ب"ال) اليمامة: بينها وبين البحرين عشرة أيام، وهي معدودة من نجد وقاعدتها حجر • ياقوت، معجم البلدان المجلد الخامس، صז صـ ؟.

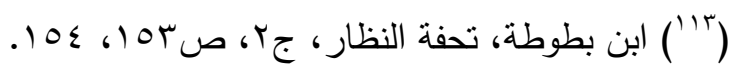

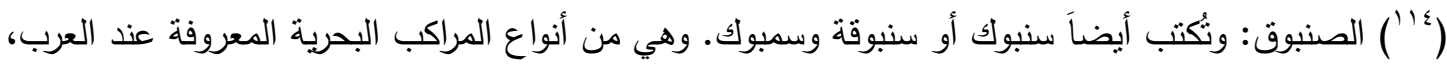

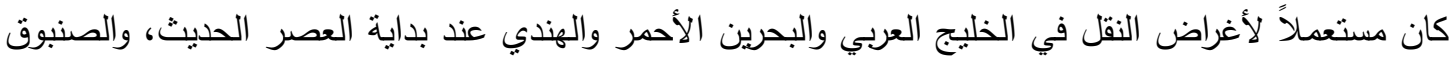
أيضاً هي سفن للغوص تنير بواسطة الأشرعة والمجاديف، وتُشتعمل للغوص بحثاً عن اللؤلؤ، كما أنها تتميز

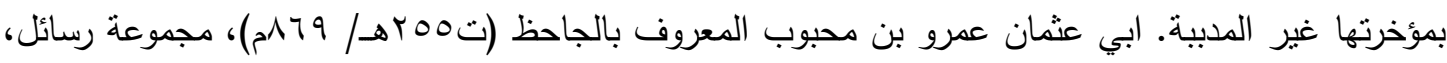
الرسالة الرابعة كتاب فخر السودان على البيضان، تحقيق عبد السلام محمد هارون، مكتبة الخانجي، القاهرة، ع 97 ام، صل V آT، مصطفى عبد الكريم الخطيب، معجم المصطلحات والألقاب التاريخية، مؤسسة الرسالة،

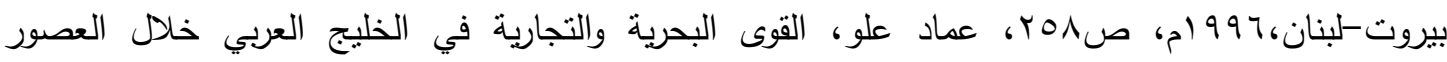

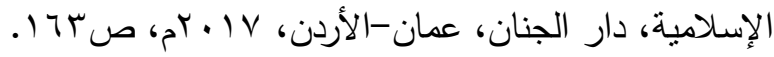

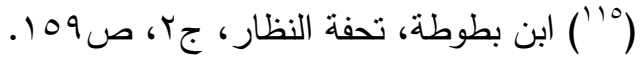

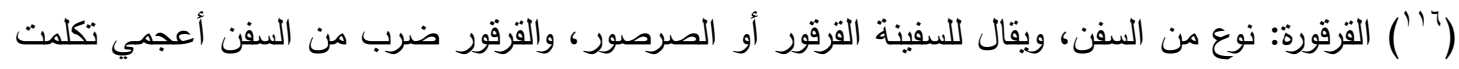

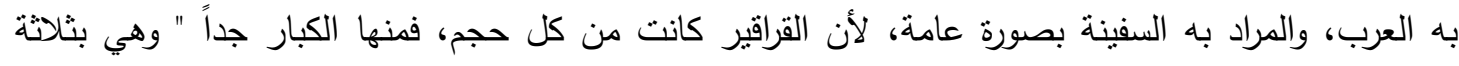

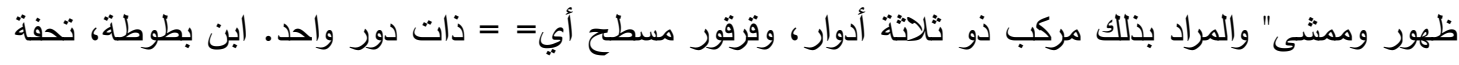

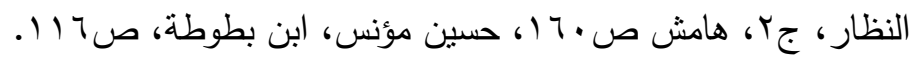

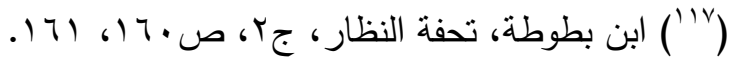
(1^) أنطاليا: بلا كبير من مشاهير بلاد الروم كان أول من نزله أنطالية بنت الروم بن اليقن بن سام بن نوح

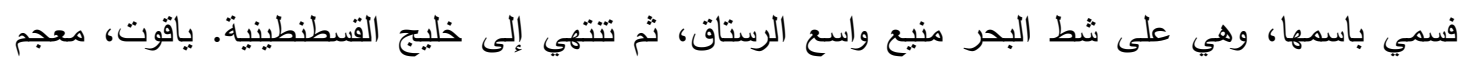

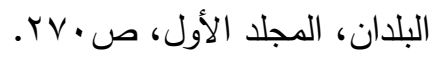

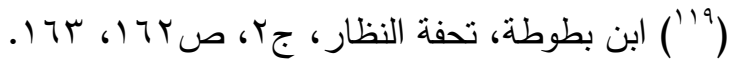

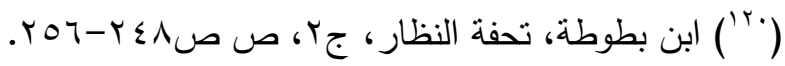

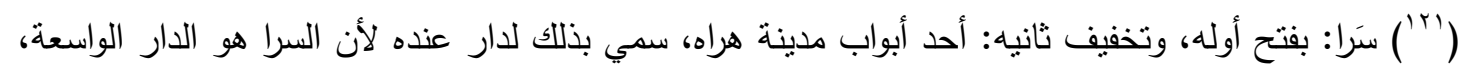

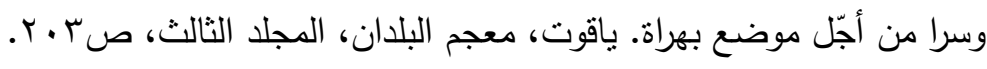




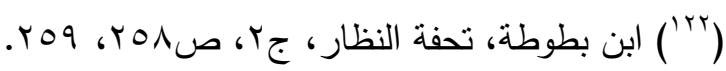

$$
\begin{aligned}
& \text { (rr) } \\
& \text { ( ( }
\end{aligned}
$$

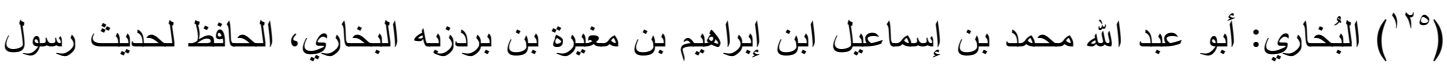

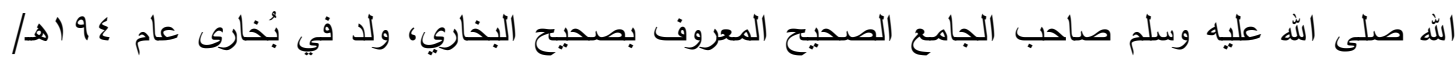

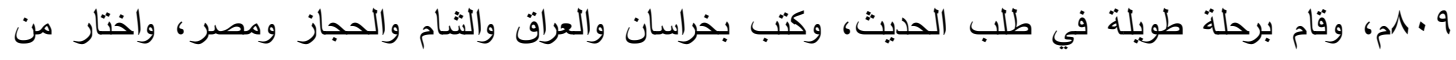

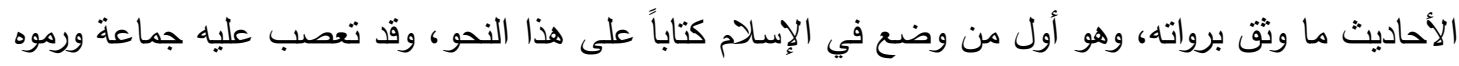

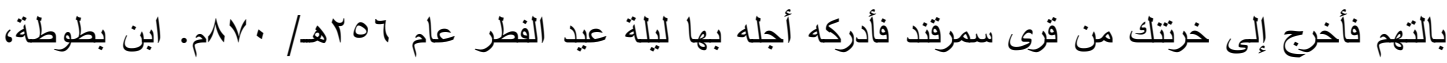

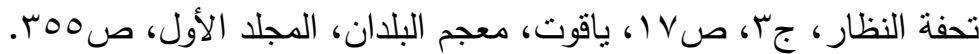

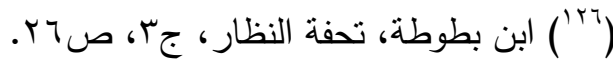

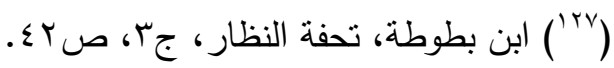

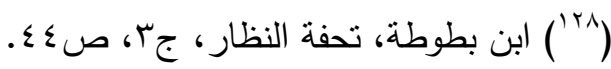

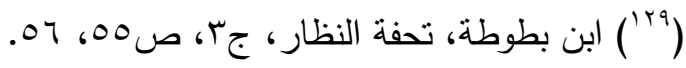

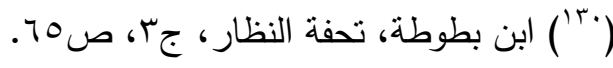

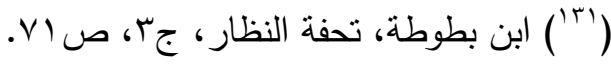

( (זبّأنَانِي: ذكر ابن بطوطة جناني بأن ضبط اسمها بفتح الجيم والنون الأولى وكسر الثانية، مدينة كبيرة

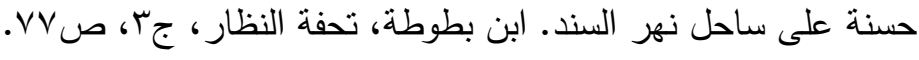

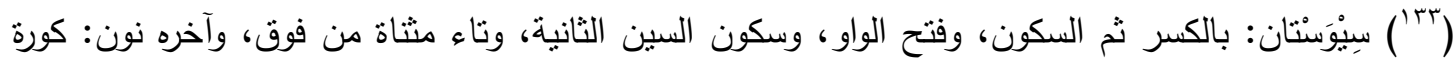

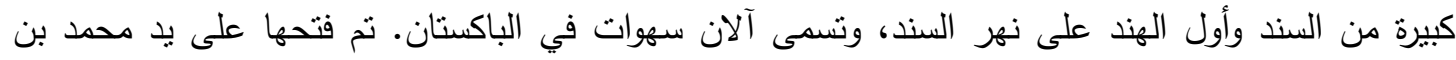

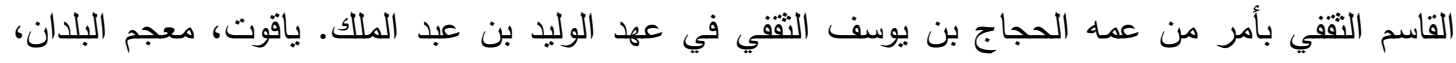

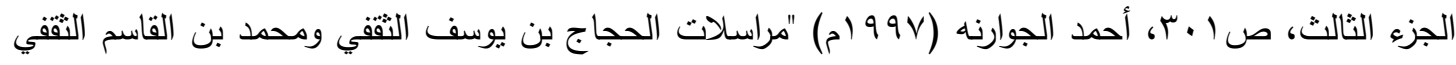
كما وردت في المصدر التاريخي فتح السند أو ججنامة دراسة وتحليل"، مجلة أبحاث اليرموك سلسلة العلوم

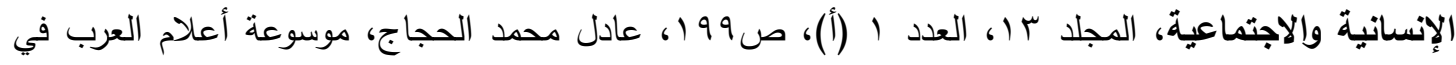

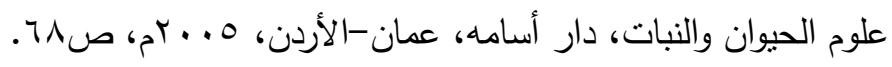

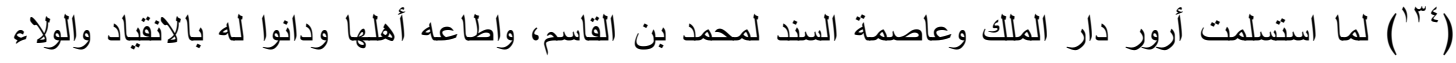
عهر بالثؤون الثرعية ودار القضاء والخطابة إلى الامام العالم برهان الملة والدين سيف السنة موسى بن يعقوب

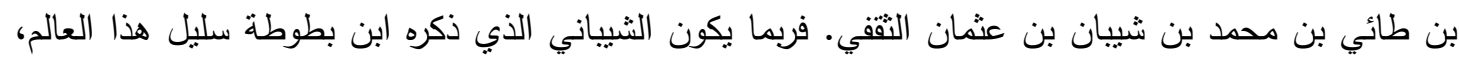

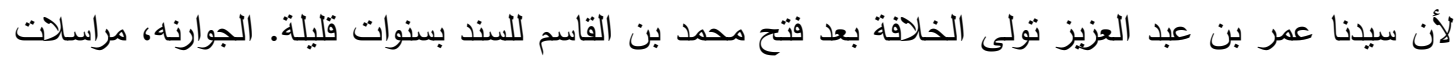

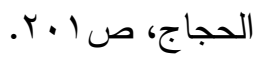

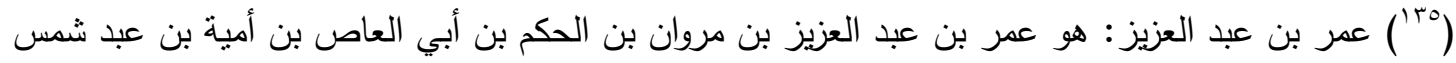

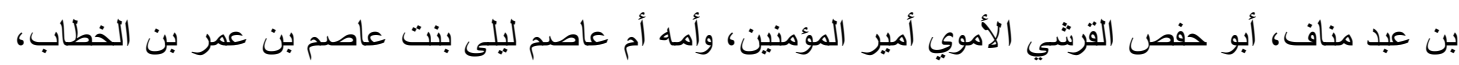

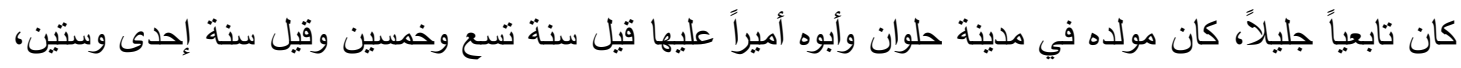


وقيل ثلاث وستين. ولما مات أبوه أخذه عمه أمير المؤمنين عبد الملك بن مروان فخلطه بولده، وقدمه على كثير منهم، وزوجه بابنته فاطمة، ولما مات عمه عبد الملك حزن عليه، ولبس المسوح تحت ثيابه سبعين يوماً. ولما

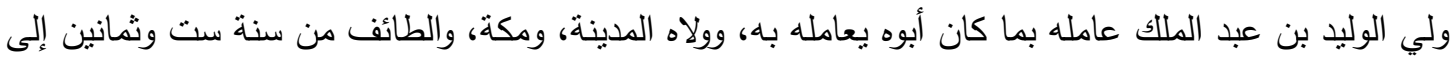

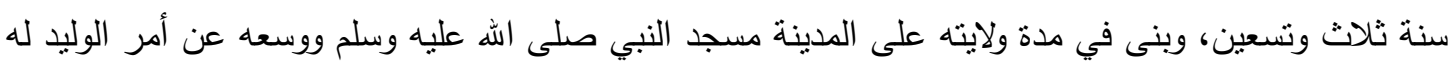
بذلك، فذخل فيه قبر النبي صلى الله عليه وسلم، وقد كان في هذه المدة من أحسن الناس معانشرة، وأعدلهم سيرة.

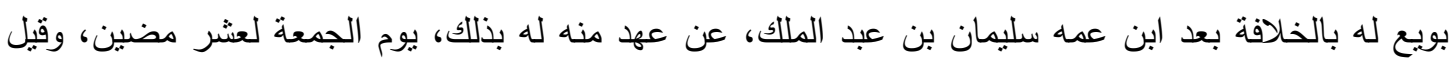

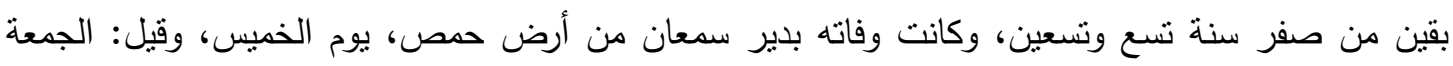

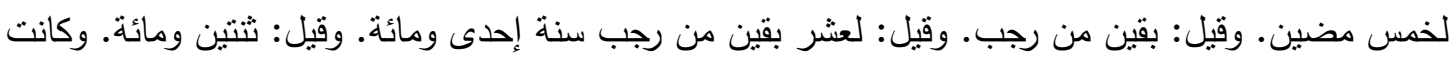

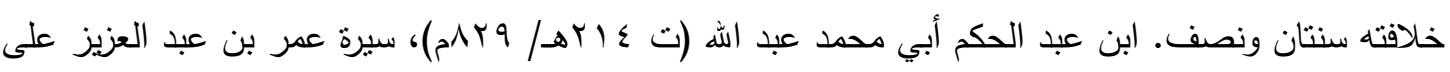

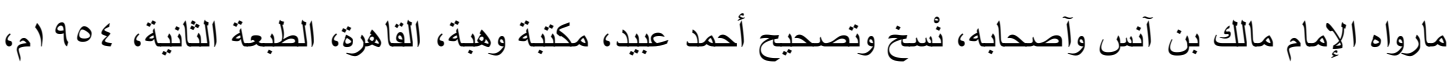

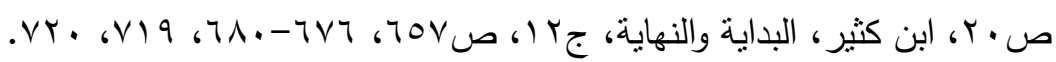

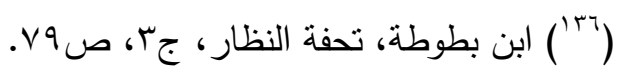

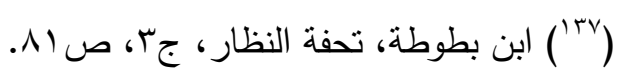

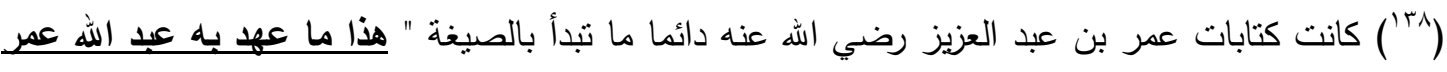

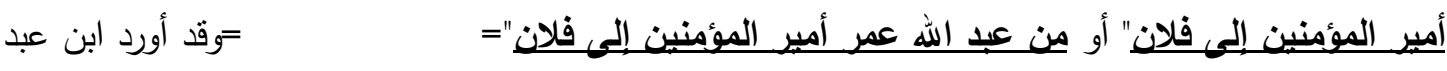

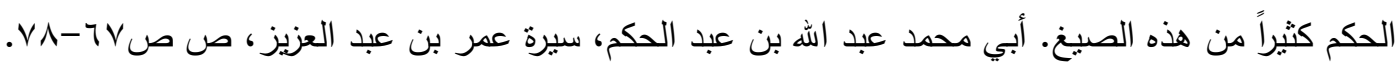

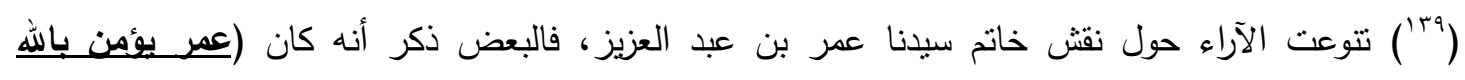

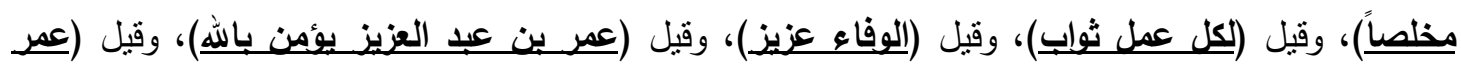

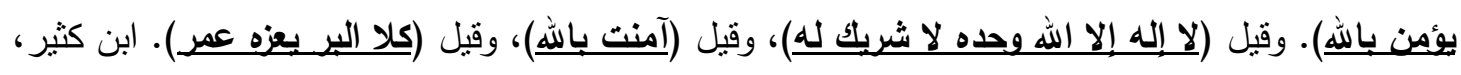

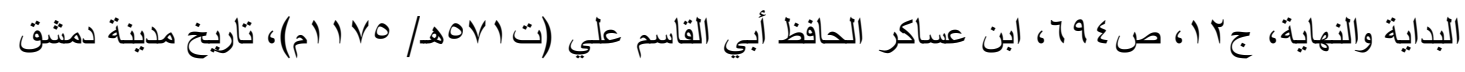

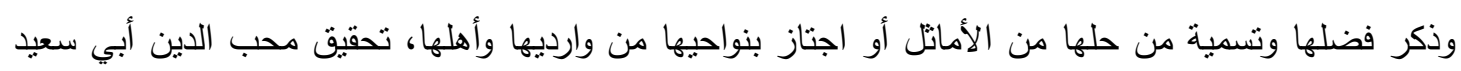

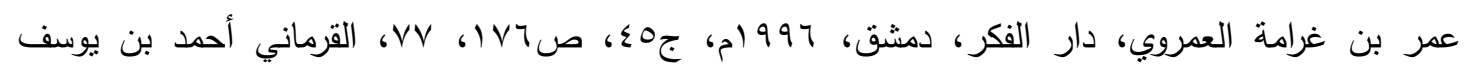

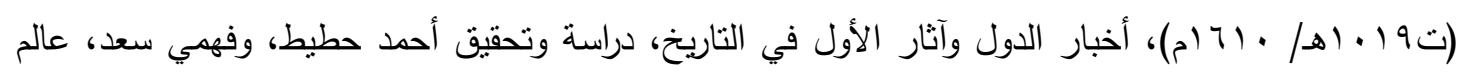

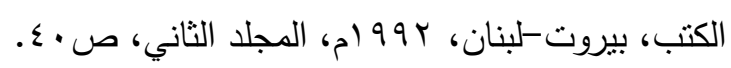

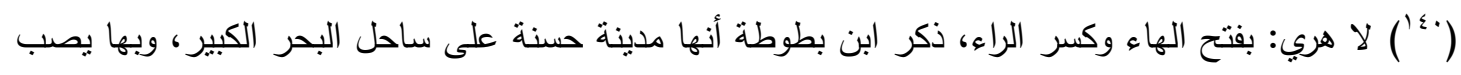

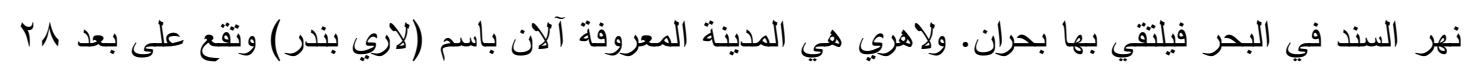

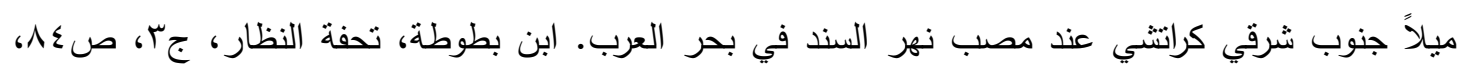

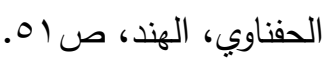

(') أبوهر : يضبطها ابن بطوطة بفتح الهاء، ويذكر أنها أول تلك البلاد الهندية، ويصفها بأنها صغيرة حسنة

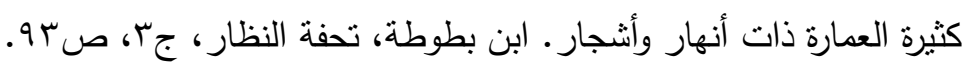

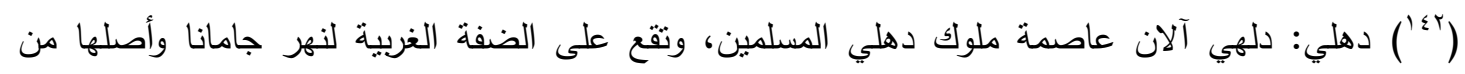
المملكة الغورية، وفيها المساجد والقصور ، ولاتزال المدينة محتفظة بطابعها القديم بعكس دهلي الجديدة. طارق بن 
فتحي بن سلطان (0 rم)، "المجاهد شهاب الدين أبو المظفر محمد بن سام الغوري ودوره في فتوح شبه القارة

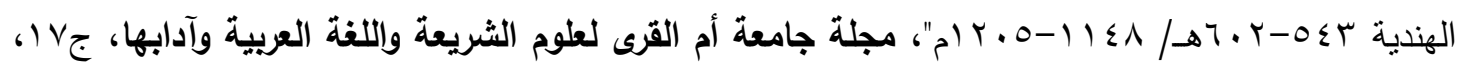

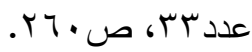

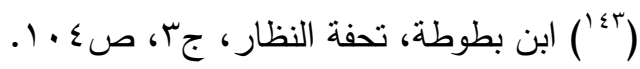

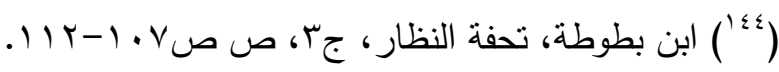

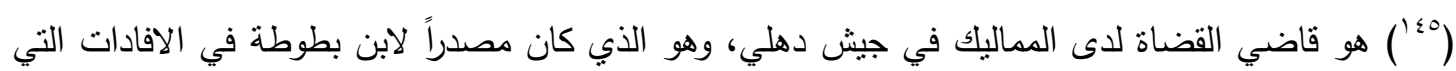

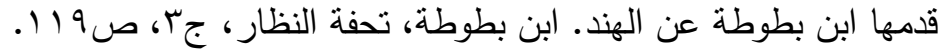

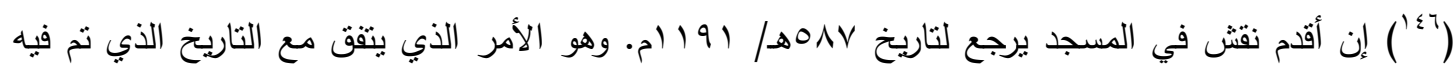

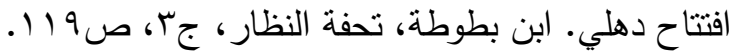

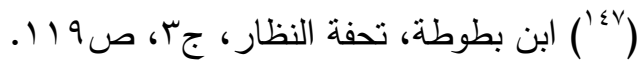

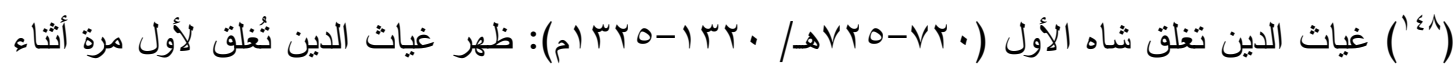

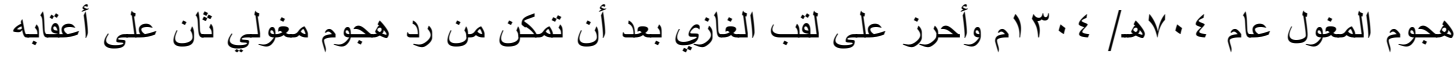

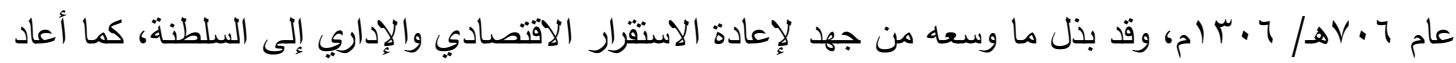
بسط السيطرة الإسلامية على الدكن. ابن بطوطة، تحفة النظار، ج؟، صوج ا، بوزورث، الأسرات الحاكمة،

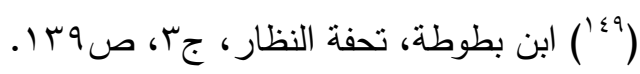
('0.0) الملك: لقب يُطلق على الرئيس الأعلى للسلطة الزمنية، وهو لقب معروف في اللغات السامية، وقد ورد ذكره في النقوش العربية القديمة، وقد ورد اللفظ في بعض الآيات القرآنية. ولم يُعرف هذا اللقب بصفة رسمية في

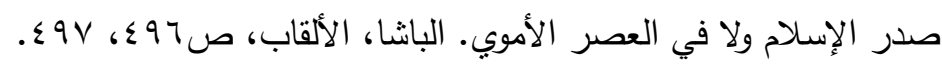

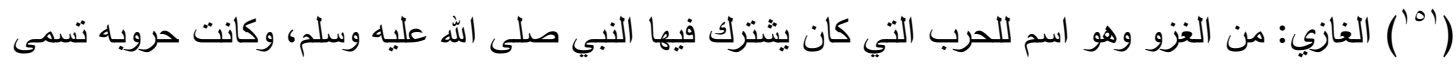
المغازي. وهذا اللقب من الألقاب السنية. وقد ظهر اللقب في أماكن الحدود القريبة من البلاد غير الإسلامية، وكان ينعت بها هؤلاء الذين كانوا يخوضون غمار الحروب في سبيل الإسلام، أو ينظاهرون بذللك. الباشا،

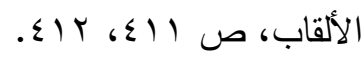

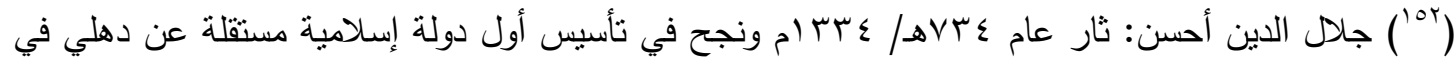

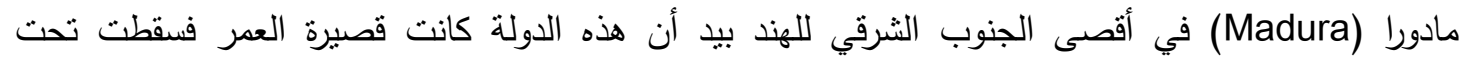

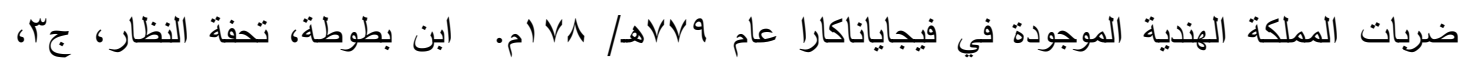

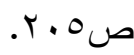
( ) بلاد المعبر: ذكر ابن بطوطة أنها من أخصب بلاد الهند وبينها وبين دهلي مسيرة ستة أثهر. ابن

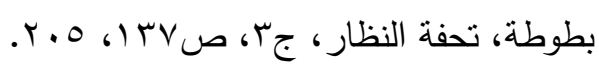

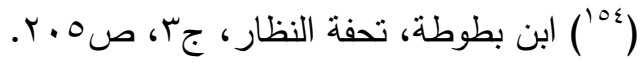

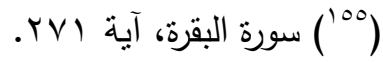

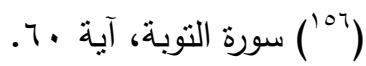


( )

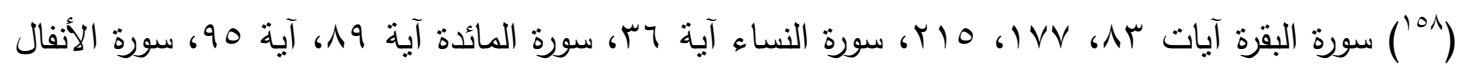

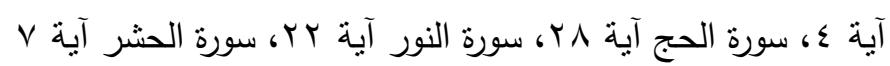

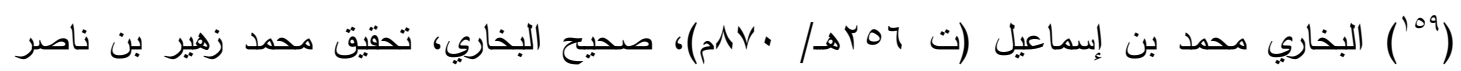

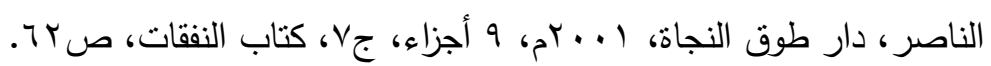

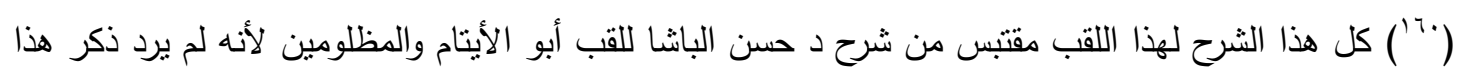

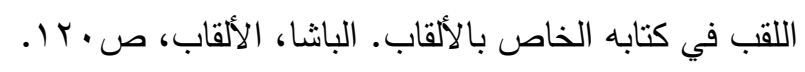

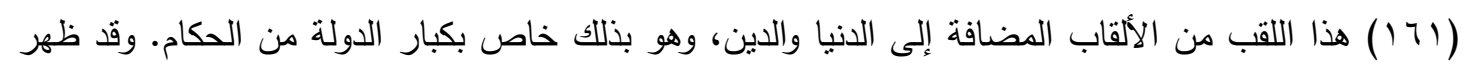

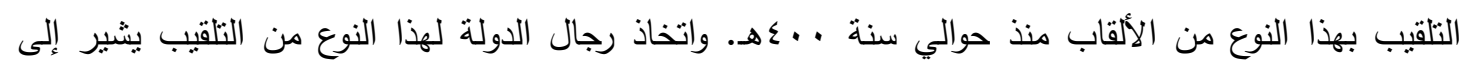

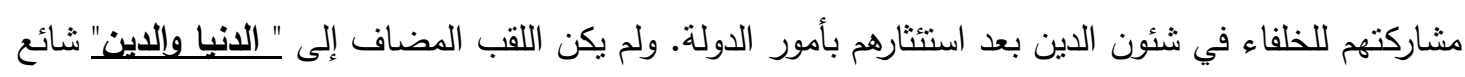
الاستعمال على النقود. ونلاحظ أن هذا اللقب المضاف إلى "اللدين" بمجرد ظهوره انتشر في جميع أنحاء العالم الإسلامي واستعمل لجميع طبقات الأمة الإسلامية من سلاطين إلى جند، ومن موظفين إلى تجار ولقد كان لقب

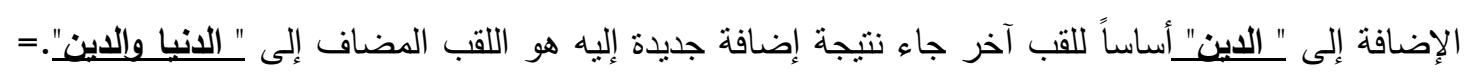

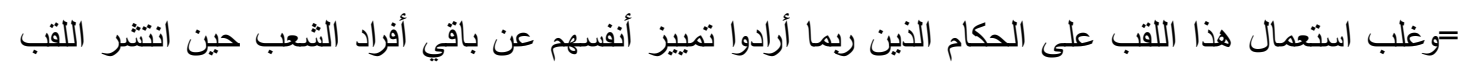
المضاف إلى " الدين" أثناء القرن الخامس الهجري، وذللك حتى لا ينتقص اللقب من مركزهم. الباشا، الألقاب، صU

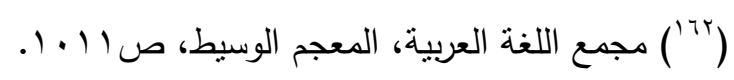

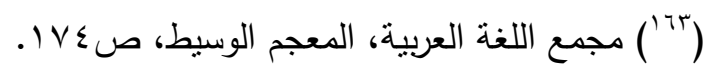

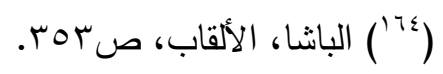
( (70) السلطان: في اللغة من السلاطة بمعنى القهر ومن هنا أطلق على الوالي. وهذا اللفظ مأخوذ من اللغة

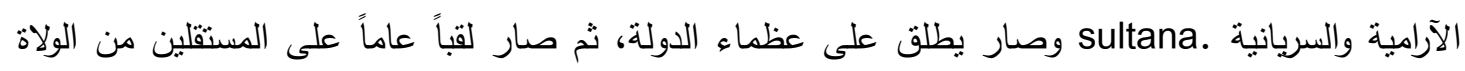

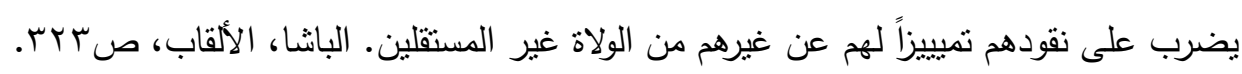

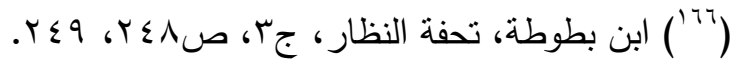

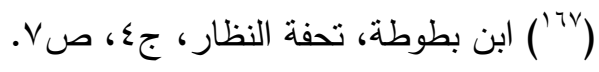

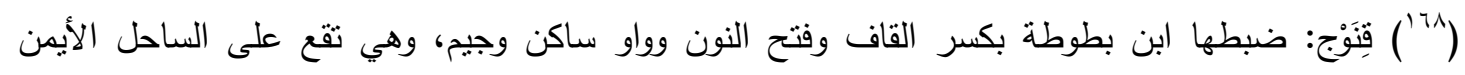

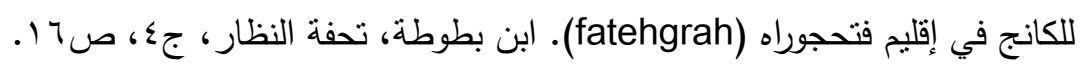

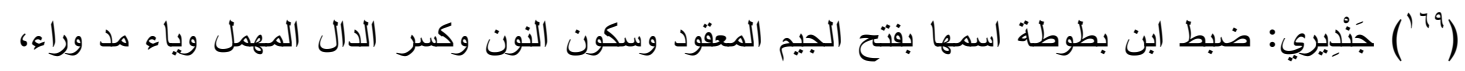

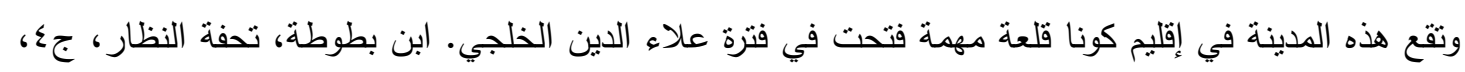
صמוr

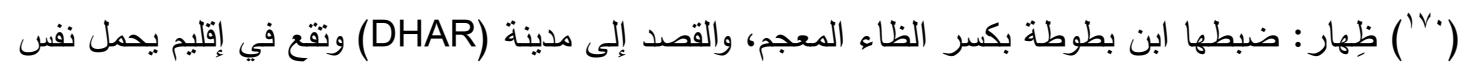

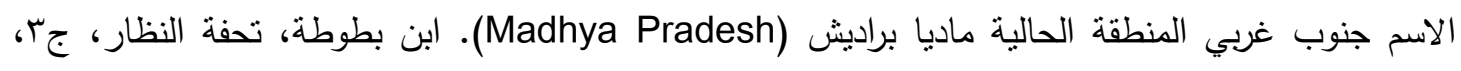

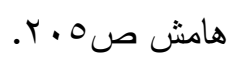




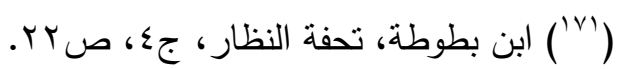

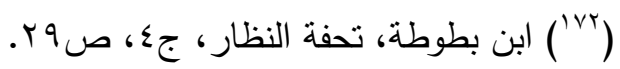

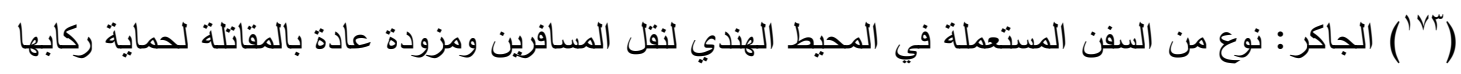
من هجمات لصوص البحر (القراصنة) وتتسع لحمل العديد من الأفراد والمؤون. أمل عبد السلام السيد القطري لهي

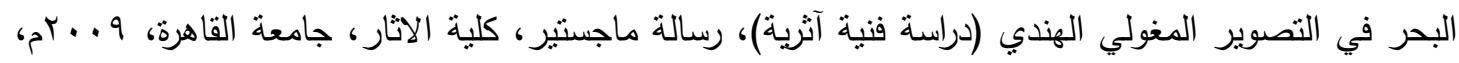

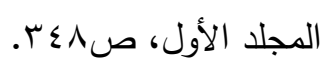

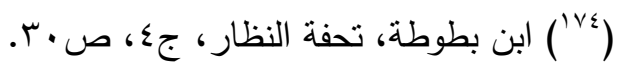

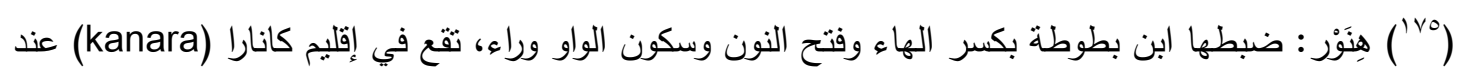

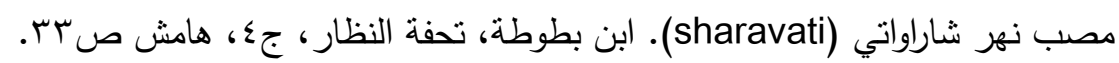

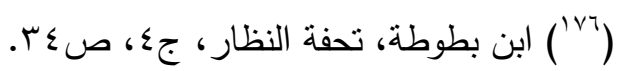

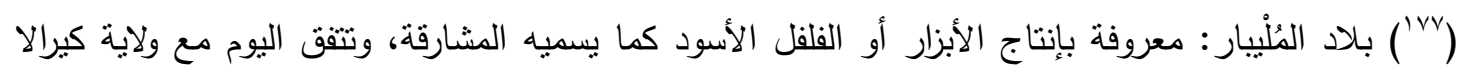
إحدى ولايات الهند. ابن بطوطة، تحفة النظار ، جء، هامش صهم.

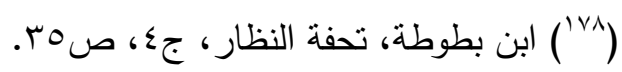

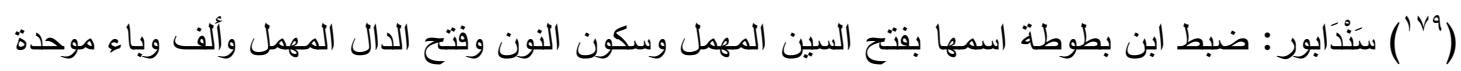
وواو مد وراء وذكر أنها جزيرة في وسطها ست وثلاثون قرية. ابن بطوطة، تحفة النظار، جء، ص است.

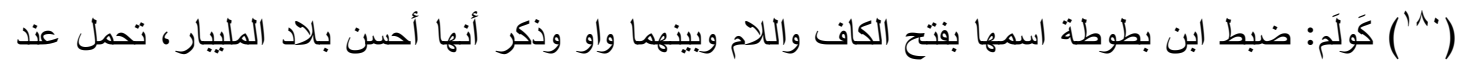

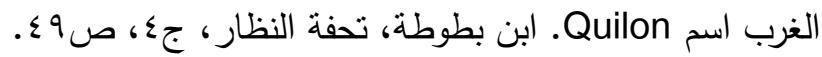
('l') مدينة أبي سرور : وصفها ابن بطوطة بأنها صغيرة على خور كبير كثيرة أنثجار النارجيل، ولاوجود للمدينة

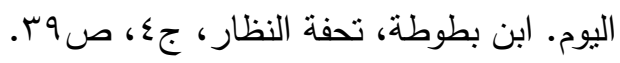

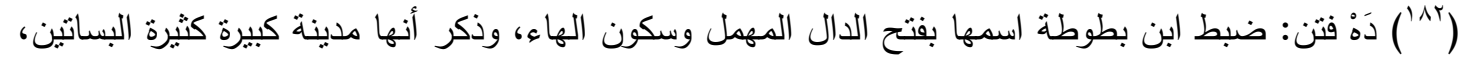
وعُرفت هذه المدينة بفالاريا طانام التي توجد على بعد خمسة أميال شمال كاطانور على الساحل الجنوبي للوادي

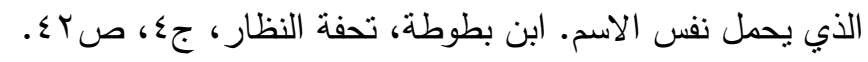

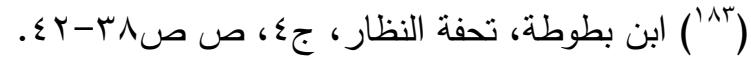

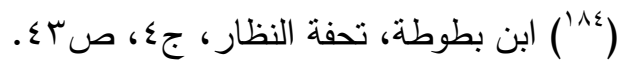
(1^1') بدفتن: هي دارما باطا نام (مكان الرحمة) الموجودة على جزيرة كونها التقاء مجاري نهر تيليشيري ونهر

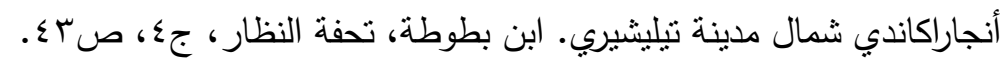
(1) قالقُوطُ: ضبط ابن بطوطة اسمها بقافين وكسر اللام وضم القاف الثاني وآخره طاء مهمل، وهي تقع شمال

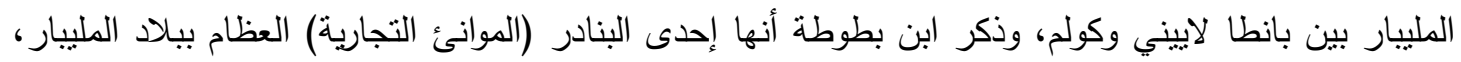

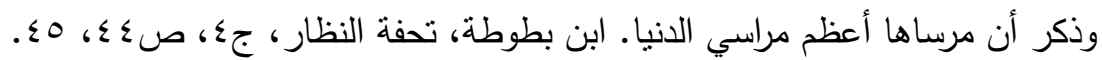

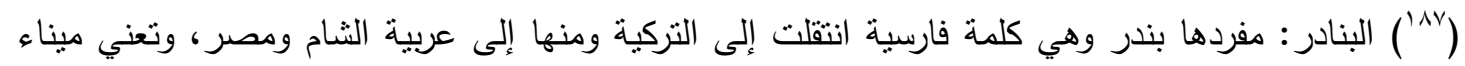
التجارة. مصطفى بركات، الألقاب والوظائف العثمانية دراسة في نطور الألقاب والوظائف منذ الفتح العثماني 


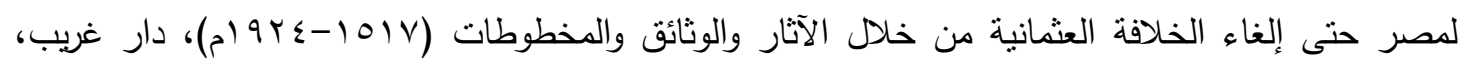

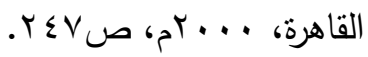

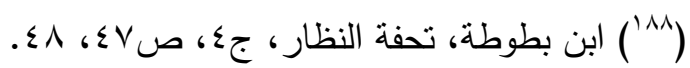

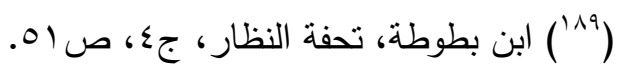

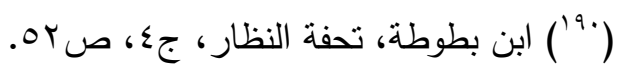

(19) الثاليات: ضبط ابن بطوطة اسمها بالثين المعجم وألف ولام وياء آخر الحروف وألف وتاء معلوة، وذكر

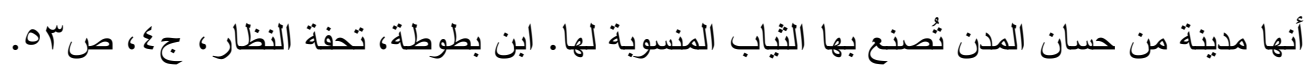

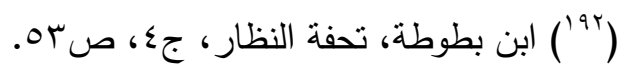
(19 (1) ذيبة المَكلّ: ذيبة على لفظ مؤنث الذيب، وهي كلمة من أصل سنسكري دفيبا (Dvipa) ومعناها جزيرة،

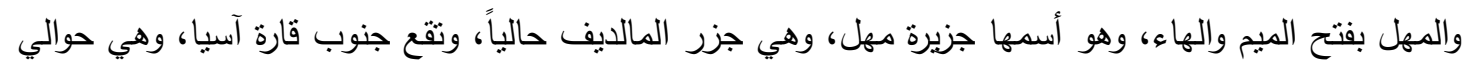

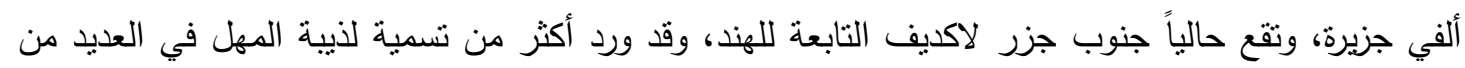

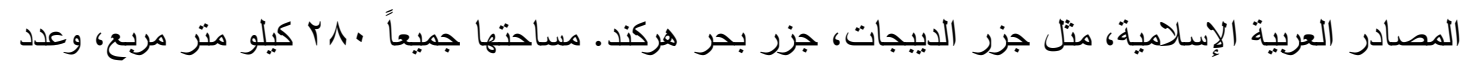

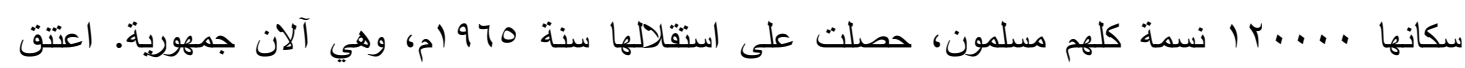

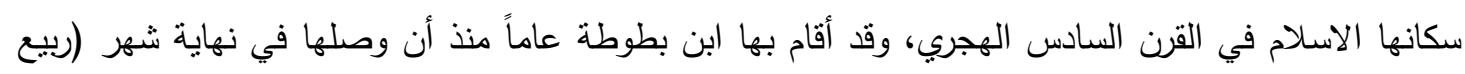

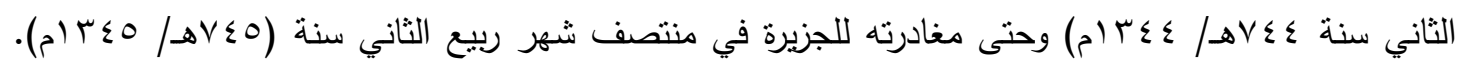

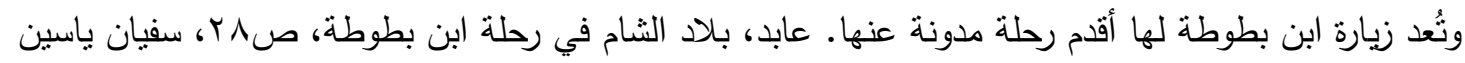

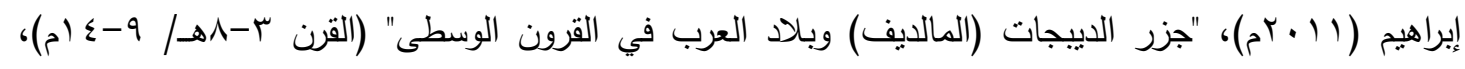

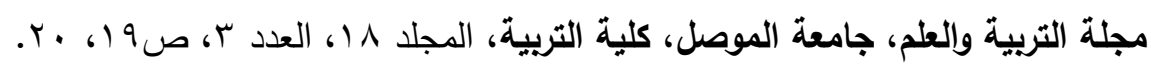

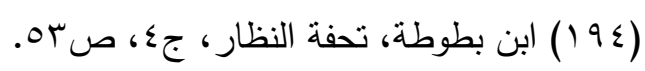

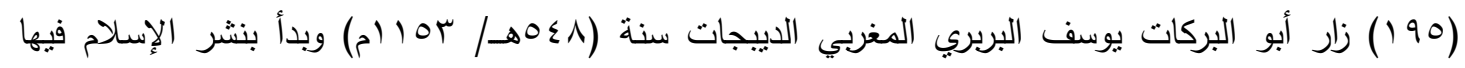

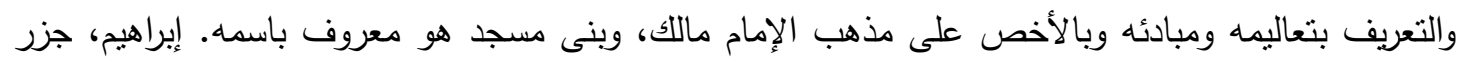

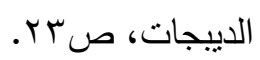
(97 (1) كان هذا السلطان يُدعى "درمس كالامنجا" قبل الإسلام فاستبدل اسمه بعد إسلامه إلى "درمس محمد بن

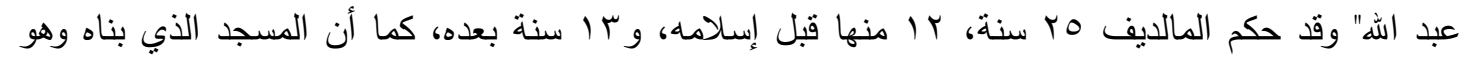

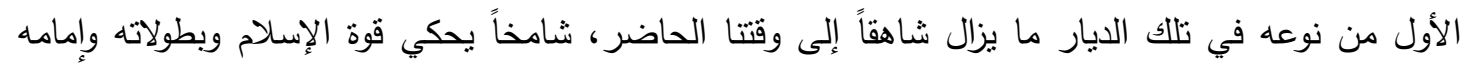

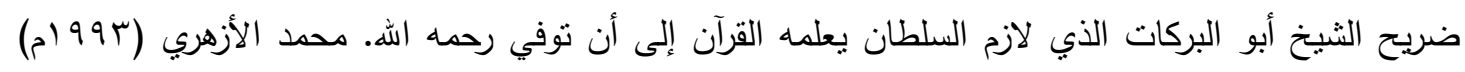

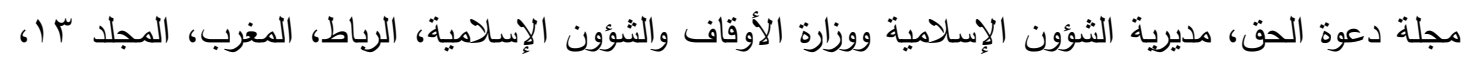

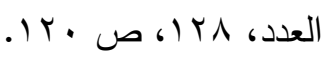

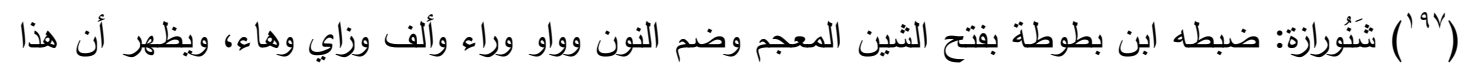

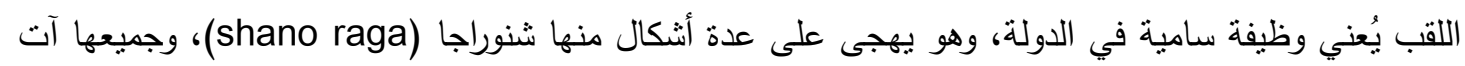

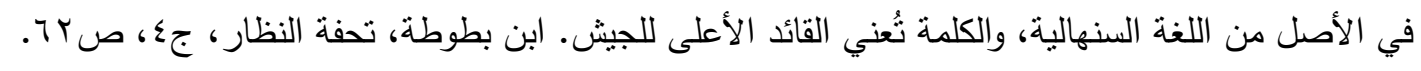


(19^ال) البربري: البربر شعب أكثره قبائل نسكن الجبال في شمال إفريقية، والجمع برابر ، وبرابرة، والبربري واحد من البربر ـ مجمع اللغة العربية، المعجم الوسيط، صلحــ

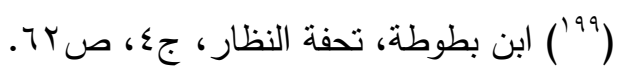

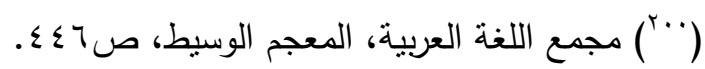
(1+r) كنلوس: ذكرها ابن بطوطة بأنها جزيرة حسنة فيها المساجد الكثيرة. ابن بطوطة، تحفة النظار، جع؛،

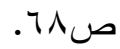
(r.r.r سَرَنْدِيب: بفتح أوله وثانيه، وسكون النون، ودال مهملة مكسورة، وياء مثثاة من تحت، وباء موحدة، وذكر ياقوت أنه لا يدري ماذا تُعني كلمة سرن، ديب بلغنة الهنود: هو الجزيرة، وهي جزيرة عظيمة في بحر هركند

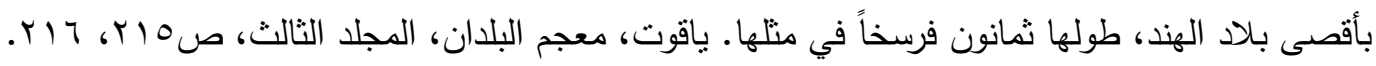

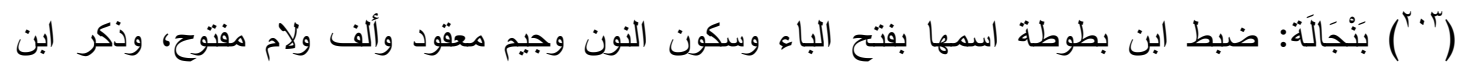

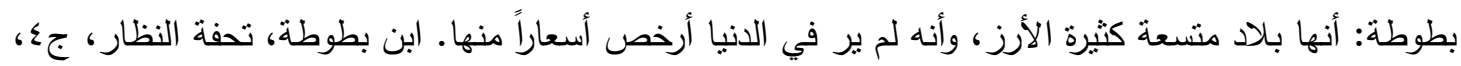
.

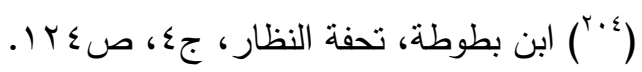

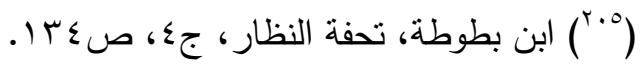
(7) (بلاد الخِطا: ضبط ابن بطوطة اسمها بكسر الخاء المعجم، وطاء مهمل، وذكر: أنها أحسن بلاد الدنيا

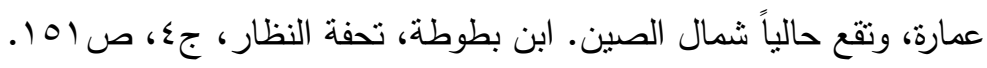

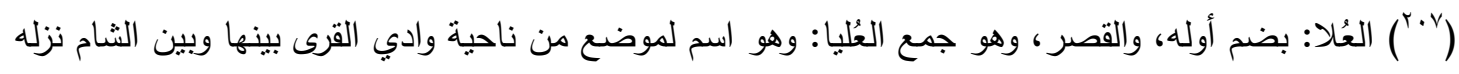
رسول الله، صلى الله عليه وسلم، في طريقه إلى تبوك وبُنَى مكان مصلاه مسجد. ياقوت، معجم البلدان، المجلد

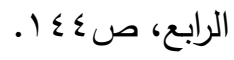

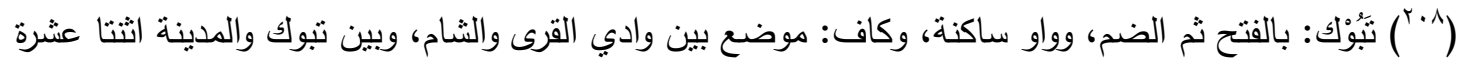

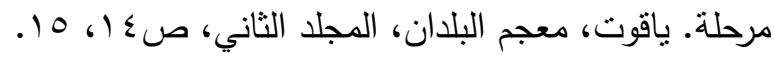

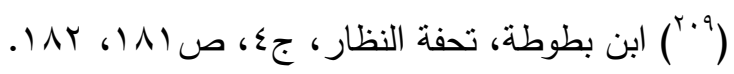

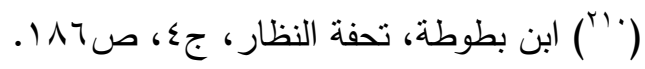

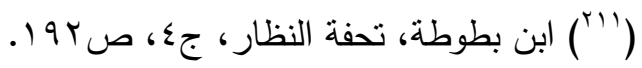

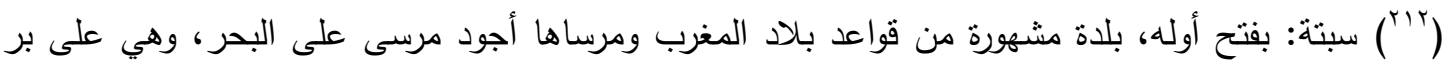

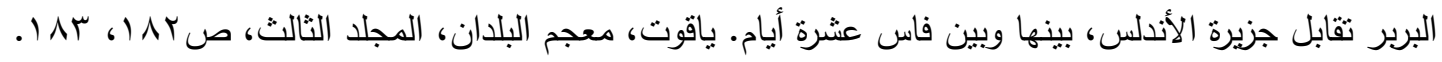
(r)

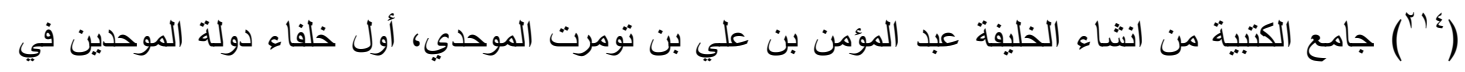

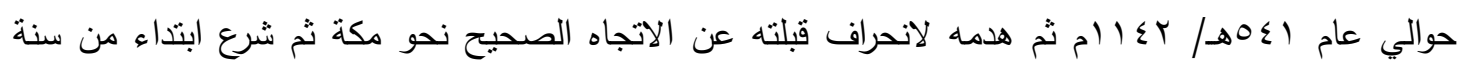

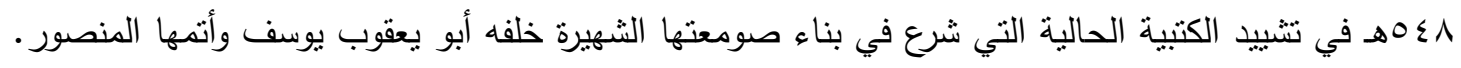
وتقع الصومعة في الركن الثمالي الثرقي للمسجد الجامع ويبلغ علوها لI منز ، وماتزال شامخة إلى اليوم. 
عثمان عثمان إسماعيل، ناريخ العمارة الإسلامية والفنون التطبيقية بالمغرب الأقصى، الجزء الثالث، عصر دولة

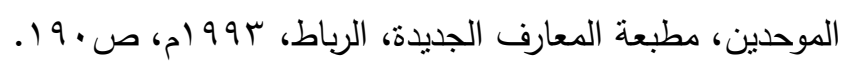

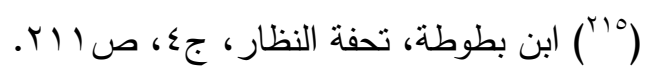

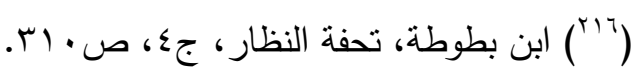

